\author{
UNIVERSIDADE DE BRASÍLIA \\ FACULDADE DE CIÊNCIAS DA SAÚDE \\ PROGRAMA DE PÓS-GRADUAÇÃO EM CIÊNCIAS DA SAÚDE
}

MARCELA MEDEIROS DE FREITAS

OBTENÇÃO DE EXTRATOS PADRONIZADOS EM ÁCIDO CLOROGÊNICO, RUTINA E ISOQUERCITRINA A PARTIR DAS FOLHAS DE Morus nigra L.: INIBIÇÃO DE TIROSINASE E CITOTOXICIDADE

Dissertação apresentada como requisito parcial para obtenção do Título de Mestre em Ciências da Saúde pelo Programa de Pós-Graduação em Ciências da Saúde da Universidade de Brasília.

Orientador: Pérola Oliveira Magalhães Dias Batista

BRASÍLIA 


\section{OBTENÇÃO DE EXTRATOS PADRONIZADOS EM ÁCIDO CLOROGÊNICO, RUTINA E ISOQUERCITRINA A PARTIR DAS FOLHAS DE Morus nigra L.: INIBIÇÃO DE TIROSINASE E CITOTOXICIDADE}

Dissertação apresentada como requisito parcial para obtenção do Título de Mestre em Ciências da Saúde pelo Programa de Pós-Graduação em Ciências da Saúde da Universidade de Brasília.

BANCA EXAMINADORA

Profa. Pérola de Oliveira Magalhães Dias Batista - presidente Universidade de Brasília

Edemilson Cardoso da Conceição

Universidade Federal do Goiás

Yris Maria Fonseca-Bazzo

Universidade de Brasília 
Dedico este trabalho aos meus pais, eternos incentivadores. 


\section{AGRADECIMENTOS}

À Deus, criador de todas as coisas.

À minha mãe, farmacêutica, de quem herdei a fé e o interesse pela ciência e pesquisa.

Ao meu pai pela companhia durante a minha jornada acadêmica, pela ética, organização e determinação ensinados.

À Professora Pérola pela amizade, orientação e confiança em mim depositada durante anos de trabalho.

À minha avó Inês e meu tio Eugênio Mariano, incentivadores da busca pelos meus sonhos profissionais.

À minha irmã Manuela, meu cunhado Dion, meus sobrinhos Isabella e Matthew, pela motivação de crescimento profissional.

À Professora Yris Maria Fonseca-Bazzo, Professora Damaris Silveira e Professor Mauricio Homem de Mello pelos ensinamentos.

Ao Professor Christopher Fagg pela identificação e coleta do material botânico utilizado.

Ao Professor Marcílio Cunha do Laboratório de Tecnologia de Medicamentos, Alimentos e Cosméticos, pelo uso do tamis.

À Professora Eloisa Dutra Caldas do Laboratório de Toxicologia pelo uso do liofilizador.

Ao Professor Edivaldo Ximenes do Laboratório de Enzimologia pelo uso do equipamento de Cromatografia Líquida de Alta Eficiência. 
À Professora Eliete Guerra do Laboratório de Histopatologia Bucal e Professora Yanna Karla de Medeiros Nóbrega do Laboratório de Pesquisas em Doenças Imunogenéticas e Crônico-degenerativas pela disponibilização do material para realização dos ensaios de cultura celular.

À CAPES pela bolsa de mestrado concedida durante o curso de Pós-Graduação.

À FAPDF pelo auxílio financeiro concedido através do processo 193.000.484/2011.

Ao CNPq pelo apoio financeiro concedido através do processo 564208/2010-8.

Aos colegas de laboratório pelos ensinamentos e momentos de descontração.

Aos meus amigos pelo apoio. 


\section{RESUMO}

A melanogênese é um processo responsável pela produção de melanina, a qual é armazenada em melanócitos, que contêm tirosinase. Esta enzima é responsável pela hiperpigmentação da pele devido à superprodução de melanina. A inibição desta enzima é um alvo na indústria dos cosméticos, uma vez que controla condições indesejáveis da pele. Espécies de plantas do género Morus são conhecidas pelos usos benéficos oferecidos em diferentes partes da planta, incluindo a inibição da tirosinase. Assim, este projeto teve como objetivo estudar a atividade inibitória da tirosinase por extratos das folhas de Morus nigra, bem como a caracterização do perfil cromatográfico do seu extrato e viabilidade de incorporação em produtos cosméticos a partir de sua citotoxicidade, a fim de tornar-se uma nova opção terapêutica de fonte natural. Folhas de $M$. nigra foram coletadas, pulverizadas, igualmente divididas em cinco lotes e o extrato padronizado foi obtido por maceração passiva. Não houve diferença significativa entre os lotes para teor de sólidos totais, rendimento e teor de umidade, o que demonstra uma boa reprodutibilidade do processo de extração, também demonstrado pelo perfil cromatográfico de CCD. Atividade enzimática de tirosinase foi determinada para cada lote, fornecendo a percentagem de inibição da enzima e os valores de $I_{50}$ obtidos através da construção de curvas dose-resposta e comparados com o ácido kójico, um inibidor conhecido da tirosinase. Alta atividade de inibição da tirosinase foi observada (acima de $90 \%$ a $15,625 \mu \mathrm{g} / \mathrm{mL}$ ) e valores de $\mathrm{IC}_{50}$ entre $5,00 \mu \mathrm{g} / \mathrm{mL} \pm$ 0,23 e $8,49 \mu \mathrm{g} / \mathrm{mL} \pm 0,59$, comparável ao ácido kójico $(3,37 \mu \mathrm{g} / \mathrm{mL} \pm 0,65)$. De acordo com as diretrizes da $\mathrm{ICH}$ e da Anvisa, o método cromatográfico empregado utilizando Cromatografia Líquida de Alta Eficiência (CLAE) foi validado. A análise por CLAE revelou a presença de ácido clorogênico, rutina e, seu composto majoritário, isoquercitrina. Desta forma, o extrato padronizado das folhas de M. nigra foi padronizado utilizando estes polifenóis como marcadores. A citotoxicidade foi avaliada pelo ensaio MTT em melanomas de murino (B16F10), queratinócitos humano (HaCat) e fibroblastos de camundongo (L-929). Não foi observada citotoxicidade para as linhagens celulares nos valores de $\mathrm{IC}_{50}$ da tirosinase. Este estudo demonstrou o potencial do extrato de $M$. nigra como um promissor agente de branqueamento de fonte natural contra hiperpigmentação cutânea.

Palavras-chave: Morus nigra; hiperpigmentação; tirosinase; inibição; validação. 


\begin{abstract}
Melanogenesis is a process responsible for melanin production, which is stored in melanocytes containing tyrosinase. This enzyme is responsible for skin hyperpigmentation due to the overproduction of melanin. Inhibition of this enzyme is a target in the cosmetics industry, since it controls undesirable skin conditions. Plant species of the Morus genus are known for the beneficial uses offered in different parts of the plant, including tyrosinase inhibition. Thus, this project aimed to study the inhibitory activity of tyrosinase by extracts from Morus nigra leaves, as well as the characterization of the chromatographic profile of its extract and viability of incorporation in cosmetics from their cytotoxicity, in order to become a new therapeutic option from a natural source. M. nigra leaves were collected, pulverized, equally divided into five batches and the standardized extract was obtained by passive maceration. There was no significant difference between batches for total solids content, yield and moisture content, which shows good reproducibility of the extraction process also demonstrated by TLC chromatographic profile. Tyrosinase enzymatic activity was determined for each batch, providing the percentage of enzyme inhibition and $\mathrm{IC}_{50}$ values obtained by constructing dose-response curves and compared with kojic acid, a well-known tyrosinase inhibitor. High inhibition of tyrosinase activity was observed (above $90 \%$ at $15,625 \mu \mathrm{g} / \mathrm{mL}$ ) and $\mathrm{IC}_{50}$ values ranging from $5.00 \mu \mathrm{g} / \mathrm{mL} \pm 0.23$ to $8.49 \mu \mathrm{g} / \mathrm{mL} \pm 0.59$, comparable to kojic acid (3.37 $\mu \mathrm{g} / \mathrm{mL} \pm 0.65$ ). According to $\mathrm{ICH}$ and Anvisa guidelines, the chromatographic method employed using High Profile Liquid Chromatography (HPLC) was validated. HPLC analysis revealed the presence of chlorogenic acid, rutin and its major compound, isoquercitrin. Thus, M. nigra leaf extract was standardized using these polyphenols as markers. Cytotoxicity was assessed by MTT assay on murine melanomas (B16F10), human keratinocytes (HaCat) and mouse fibroblasts (L-929). Cytotoxicity was not observed to the cell lines in tyrosinase $I_{50}$ values. This study demonstrated the potential of $M$. nigra extract as a promising whitening agent of natural source against skin hyperpigmentation.
\end{abstract}

Key words: Morus nigra; hyperpigmentation; tyrosinase; inhibition; validation. 


\section{LISTA DE FIGURAS}

Figura 1 Estrutura cristalográfica da tirosinase de Bacillus megaterium com tirosina no sítio ativo. .23

Figura 2 Modelo pictorial da tirosinase (centros de cobre) ....................................24

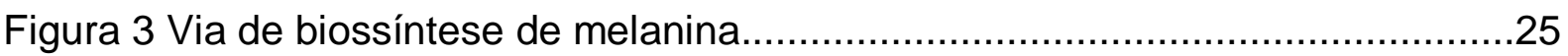

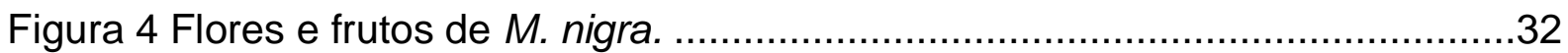

Figura 5 Exsicata de M. nigra depositada no Herbário da Universidade de Brasília, voucher Fagg CW 2302.

Figura 6 Esquema de divisão dos lotes e obtenção do extrato padronizado de $M$. nigra. .45

Figura 7 Teor de sólidos totais dos cinco lotes de extrato filtrado de $M$. nigra. .65

Figura 8 Teor de umidade em cada extração após liofilização.

Figura 9 Cromatografia em camada delgada dos extratos padronizados de $M$. nigra (20 mg/mL) (A) eluente: hexano-acetato de etila (7:3); (B) cromatoplaca revelada com anisaldeído e aquecida

Figura 10 Cromatografia em camada delgada dos extratos padronizados de $M$. nigra (20 mg/mL) revelados com NP-PEG visualizados em câmara UV $(\lambda=365 \mathrm{~nm})$. P: polifenóis ácido clorogênio, rutina e isoquercitrina $(0,33 \mu \mathrm{g} / \mathrm{mL})$. .70

Figura 11 Perfil da atividade de inibição dos cinco extratos padronizados de $M$. nigra e do controle positivo ácido kójico sobre a tirosinase.

Figura 12 Valores de $\mathrm{IC}_{50}$ dos cinco extratos padronizados de $M$. nigra em relação ao controle positivo ácido kójico sobre a tirosinase com teste t de Student $(p<0,05)$.

Figura 13 Atividade de inibição da tirosinase pelos cinco extratos padronizados de M. nigra e o controle positivo após 20 minutos de reação $(A)$ lote 1A; $(B)$ lote 2A; $(C)$ lote $3 A ;(D)$ lote $4 A ;(E)$ lote $5 A ;(F)$ ácido kójico. Após 24 horas de reação $(G)$ lote $1 \mathrm{~A} ;(\mathrm{H})$ lote $2 \mathrm{~A}$; (I) lote $3 \mathrm{~A} ;(\mathrm{J})$ lote $4 \mathrm{~A}$; $(\mathrm{K})$ lote $5 \mathrm{~A} ;(\mathrm{L})$ ácido kójico.

Figura 14 Cromatograma obtido por CLAE do extrato padronizado de M. nigra 5 $\mathrm{mg} / \mathrm{mL}$. Condições de análise: coluna PurospherStar RP C18 mantida a 25웅 eluente: bomba $A$ (acido fosfórico $1 \%$, bomba $C$ (acetonitrila); detector: $D A D$; sistema de eluição: gradiente; fluxo (A) $0,3 \mathrm{~mL} / \mathrm{min}$; (B) $0,4 \mathrm{~mL} / \mathrm{min}$; (C) $0,5 \mathrm{~mL} / \mathrm{min}$; (D) $0,6 \mathrm{~mL} / \mathrm{min}$; (E) $0,7 \mathrm{~mL} / \mathrm{min}$; (F) $0,8 \mathrm{~mL} / \mathrm{min}$. 
Figura 15 Cromatograma obtido por CLAE. Condições de análise: coluna PurospherStar RP C18 mantida a 25ํㅜ; eluente: bomba A (acido fosfórico $1 \%$ ), bomba C (acetonitrila); detector: DAD; sistema de eluição: gradiente; concentração do extrato padronizado de M. nigra (A) $4 \mathrm{mg} / \mathrm{mL}$; (B) $2 \mathrm{mg} / \mathrm{mL}$; (C) $1 \mathrm{mg} / \mathrm{mL}$.

Figura 16 Cromatograma obtido por CLAE. Condições de análise: coluna: PurospherStar RP C18 mantida a 25ํㅜ; fluxo: 0,5 mL/min; eluente: bomba A (acido fosfórico $1 \%$ ), bomba C (acetonitrila); detector: DAD; sistema de eluição: gradiente. (A) padrões ácido clorogênico, rutina e isoquercitrina $10 \mu \mathrm{g} / \mathrm{mL}$ (B) extrato padronizado de $M$. nigra $\lambda=354 \mathrm{~nm}$.

Figura 17 Espectro UV do ácido clorogênico (A) padrão; (B) extrato padronizado de M. nigra.

Figura 18 Espectro UV da rutina (A) padrão; (B) extrato padronizado de M. nigra. ..82 Figura 19 Espectro UV da isoquercitrina (A) padrão; $(B)$ extrato padronizado de $M$. nigra.

Figura 20 Estruturas moleculares dos compostos identificados no extrato padronizado das folhas de M. nigra. (A) Ácido 5-O-cafeoilquínico (ácido clorogênico); (B) Quercetina-3-O-rutinosideo (rutina); (C) Quercetina-3-O-glicosideo (isoquercitrina)

Figura 21 Seletividade do método (A) Cromatograma do extrato padronizado de $M$. nigra; (B) Cromatograma da hidrólise ácida do extrato padronizado de M. nigra 2 $\mathrm{mg} / \mathrm{mL}$; (C) Cromatograma da hidrólise básica do extrato padronizado de M. nigra 2 $\mathrm{mg} / \mathrm{mL} \lambda=354$.

Figura 22 Curva de regressão linear obtida para ácido clorogênico frente ao método proposto.

Figura 23 Curva de regressão linear obtida para rutina frente ao método proposto. 94 Figura 24 Curva de regressão linear obtida para isoquercitrina frente ao método proposto.

Figura 25 Limite de quantificação pelo método visual. (A) 1-rutina e 2-isoquercitrina $0,1 \mu \mathrm{g} / \mathrm{mL}$; (B) 1-rutina e 2-isoquercitrina 0,075 $\mu \mathrm{g} / \mathrm{mL} \lambda=354 \mathrm{~nm}$. .99 Figura 26 Alteração do parâmetro comprimento de onda para robustez frente ao método proposto. (A) $\lambda=280 \mathrm{~nm}$; (B) $\lambda=330 \mathrm{~nm}$; (C) $\lambda=354 \mathrm{~nm}$. $\mathrm{T}=25^{\circ} \mathrm{C}$; Fluxo: 0,5 $\mathrm{mL} / \mathrm{min}$. 103 
Figura 27 Alteração do parâmetro temperatura para robustez frente ao método proposto. (A) temperatura $25^{\circ} \mathrm{C}$; (B) temperatura $35^{\circ} \mathrm{C}$; (C) temperatura $45^{\circ} \mathrm{C}$. Fluxo: $0,5 \mathrm{~mL} / \mathrm{min} ; \lambda=354 \mathrm{~nm}$. 104

Figura 28 Espectro UV de ácido clorogênico na variação da temperatura na avaliação da robustez frente ao método proposto (A) $35^{\circ} \mathrm{C}$; (B) $45^{\circ} \mathrm{C}$ 105 Figura 29 Espectro UV de rutina na variação da temperatura na avaliação da robustez frente ao método proposto (A) $35^{\circ} \mathrm{C}$; (B) $45^{\circ} \mathrm{C}$. 105 Figura 30 Espectro UV de isoquercitrina na variação da temperatura na avaliação da robustez frente ao método proposto (A) $35^{\circ} \mathrm{C}$; (B) $45^{\circ} \mathrm{C}$. 106

Figura 31 Alteração do parâmetro fluxo para robustez frente ao método proposto. (A) fluxo $0,3 \mathrm{~mL} / \mathrm{min}$; (B) fluxo $0,5 \mathrm{~mL} / \mathrm{min}$; (C) fluxo $0,7 \mathrm{~mL} / \mathrm{min}$. $\mathrm{T}=25^{\circ} \mathrm{C} ; \lambda=354 \mathrm{~nm} . .107$ Figura 32 Espectro UV do ácido clorogênico na variação do fluxo na avaliação da robustez frente ao método proposto. Fluxo: $0,7 \mathrm{~mL} / \mathrm{min}$. 108 Figura 33 Espectro UV da rutina na variação do fluxo na avaliação da robustez frente ao método proposto. (A) $0,3 \mathrm{~mL} / \mathrm{min}$; (B) $0,7 \mathrm{~mL} / \mathrm{min}$. 108 Figura 34 Espectro UV da isoquercitrina na variação do fluxo na avaliação da robustez frente ao método proposto. (A) $0,3 \mathrm{~mL} / \mathrm{min}$; (B) $0,7 \mathrm{~mL} / \mathrm{min}$. 109 Figura 35 Cromatograma obtido por CLAE-DAD do extrato padronizado de $M$. nigra $2 \mathrm{mg} / \mathrm{mL}$. (A) lote $1 \mathrm{~A}$; (B) lote $2 \mathrm{~A}$; (C) lote $3 \mathrm{~A}$; (D) lote 4A; (E) lote $5 \mathrm{~A} \lambda=354 \mathrm{~nm} . . .112$ Figura 36 Quantificação de ácido clorogênico, rutina e isoquercitrina nos cinco lotes de extrato padronizado de $M$. nigra. 113

Figura 37 Viabilidade celular de melanoma (B16F10), queratinócito (HaCat) e fibloblasto (L-929) em $1000 \mu \mathrm{g} / \mathrm{mL}$ e $7,81 \mu \mathrm{g} / \mathrm{mL}$ do extrato padronizado de $M$. nigra. 


\section{LISTA DE TABELAS}

Tabela 1 - Gradiente de eluição na análise por CLAE-DAD. .52

Tabela 2 - Concentração teórica para análise da exatidão de ácido clorogênico de $M$. nigra

Tabela 3 - Concentração teórica para análise da exatidão de rutina de M. nigra......57 Tabela 4 - Concentração teórica para análise da exatidão de isoquercitrina de $M$. nigra

Tabela 5 - Peso seco e rendimento dos lotes do extrato padronizado das folhas de M. nigra 66

Tabela 6 - Valores do Fator de Retenção (Rf) calculados para o extrato padronizado de $M$. nigra $(20 \mathrm{mg} / \mathrm{mL})$ revelados com anisaldeído

Tabela 7 - Valores do Fator de Retenção (Rf) calculados para o extrato padronizado de $M$. nigra $(20 \mathrm{mg} / \mathrm{mL})$ revelados com NP-PEG

Tabela 8 - Concentração de ácido clorogênico, rutina e isoquercitrina em $2 \mathrm{mg} / \mathrm{mL}$ do extrato padronizado de $M$. nigra.

Tabela 9 - Seletividade do método para o extrato padronizado de M. nigra sem processo de hidrólise. 90

Tabela 10 - Hidrólise ácida na seletividade do método 91

Tabela 11 - Hidrólise básica na seletividade do método 92

Tabela 12 - Linearidade de ácido clorogênico, rutina e isoquercitrina na análise do método por CLAE-DAD

Tabela 13 - Repetibilidade do método para quantificação de ácido clorogênico, rutina e isoquercitrina em M. nigra

Tabela 14 - Precisão inter-dia do método para quantificação de ácido clorogênico, rutina e isoquercitrina em $M$. nigra .96

Tabela 15 - Limites de detecção calculados para ácido clorogênico, rutina e isoquercitrina segundo o método baseado em parâmetros da curva analítica.

Tabela 16 - Limites de quantificação encontrados para ácido clorogênico, rutina e isoquercitrina segundo o método baseado em parâmetros da curva analítica.

Tabela 17 - Limite de quantificação determinado para rutina e isoquercitrina segundo o método visual experimental.

Tabela 18 - Limites de detecção e quantificação descritos na literatura para ácido clorogênico, rutina e isoquercitrina 100 
Tabela 19 - Exatidão do método de adição de ácido clorogênico por CLAE-DAD ..101 Tabela 20 - Exatidão do método de adição de rutina por CLAE-DAD .......................101 Tabela 21 - Exatidão do método de adição de isoquercitrina por CLAE-DAD.........102 Tabela 22 - Resultados das variações de comprimento de onda, temperatura e fluxo para ácido clorogênico no ensaio de robustez ................................................109 Tabela 23 - Resultados das variações de comprimento de onda, temperatura e fluxo

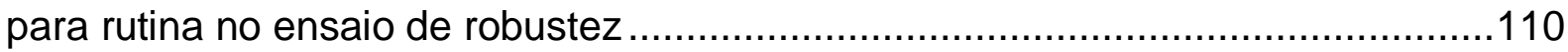
Tabela 24 - Resultados das variações de comprimento de onda, temperatura e fluxo para isoquercitrina no ensaio de robustez. 110

Tabela 25 - Valores de $\mathrm{IC}_{50}$ para melanoma, queratinócito e fibroblasto frente ao método MTT para citotoxicidade 


\section{LISTA DE ABREVIATURAS E SIGLAS}

Anvisa Agência Nacional de Vigilância Sanitária

ATCC American Type Culture Collection

B16F10 Células de melanoma de murino

CCD Cromatografia em Camada Delgada

CCK-8 Cell Counting Kit $8 \AA$

CLAE Cromatografia Líquida de Alta Eficiência

DAD Detector de Arranjo de Diodos

DHI 5,6-dihidroxiindole

DMEM Meio de Eagle modificado por Dulbecco

DNJ 1-desoxinojirimicina

Dopa 3,4-di-hidroxifenilalanina

DPR Desvio padrão relativo

$\mathrm{E}_{\text {deoxi }}$ deoxitirosinase

$\mathrm{E}_{\text {met }} \quad$ mettirosinase

Exy oxytirosinase

EPR Erro Padrão Relativo

HaCat Células de queratinócito humano

HeLa Células de câncer cervical humano

HEPES Ácido 4-(2-hidroxietil)-1-piperazinoetanossulfonico

$\mathrm{IC}_{50} \quad$ Concentração capaz de inibir $50 \%$ da atividade enzimática

IQ Indole-quinona

L-929 Células de fibroblasto de camundongo

LD Limite de Detecção

LQ L Limite de Quantificação

MS Ministério da Saúde

NP-PEG Natural Product - Polietilenoglicol

OMS Organização Mundial de Saúde

PVDF Fluoreto de polivinilideno

Renisus Relação Nacional de Plantas Medicinais de Interesse ao SUS

$\mathrm{Rf} \quad$ Fator de Retenção

ROS Espécies reativas de oxigênio

SDS Dodecil Sulfato de Sódio 
TR

Tempo de retenção

TRP1 Proteína relacionada com a tirosinase 1

TRP2 Proteína relacionada com a tirosinase 2

TYR Tirosinase

UV Ultravioleta

VIS Visível

WST-8 Sal de tetrazólio solúvel em água 
1. INTRODUÇÃO

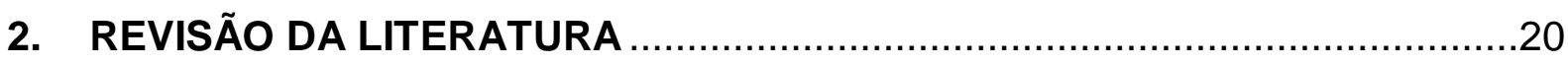

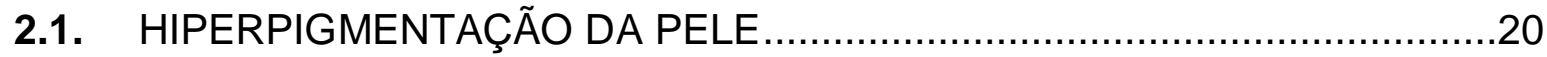

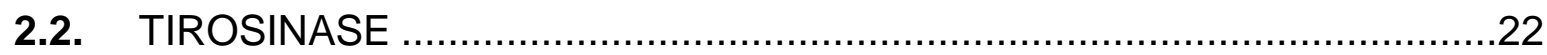

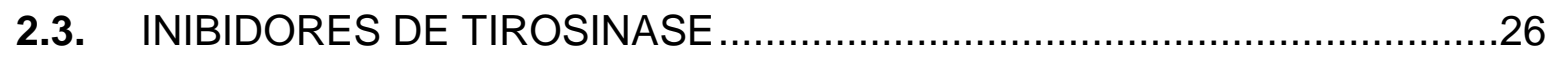

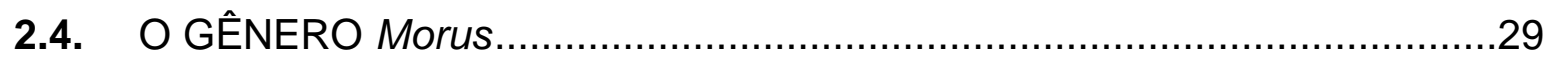

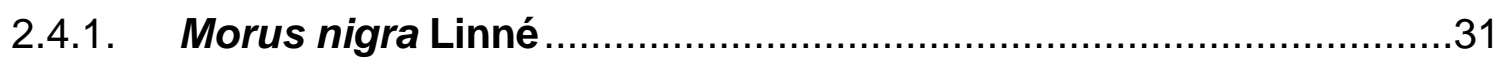

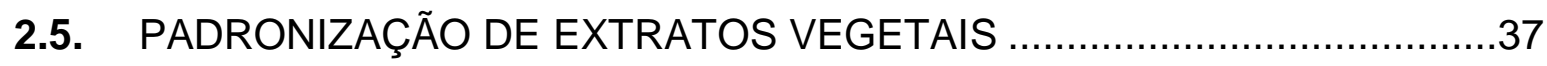

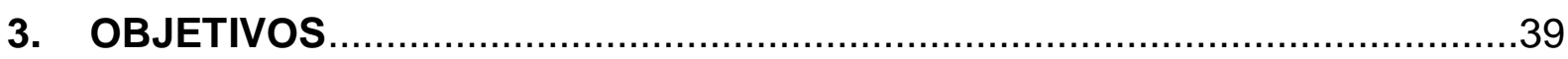

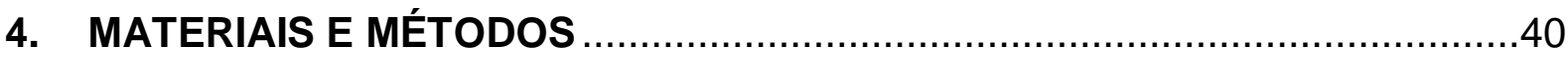

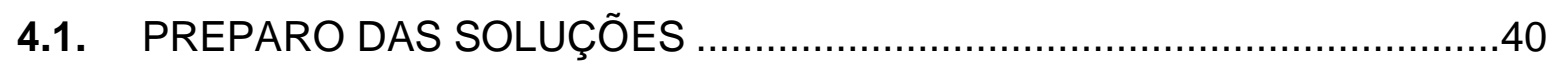

4.2. PADRONIZAÇÃO DO EXTRATO DE M. nigra ......................................42

4.2.1. Obtenção do material botânico ………….................................42

4.2.2. Obtenção do extrato padronizado das folhas de $\boldsymbol{M}$. nigra .............43

4.2.3. Reprodutibilidade do processo de obtenção do extrato

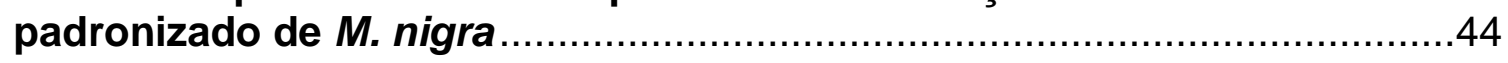

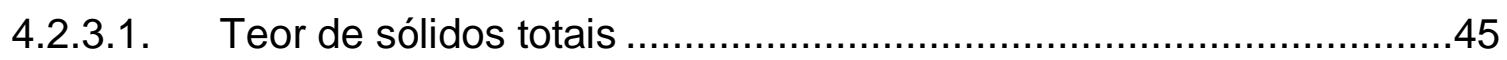

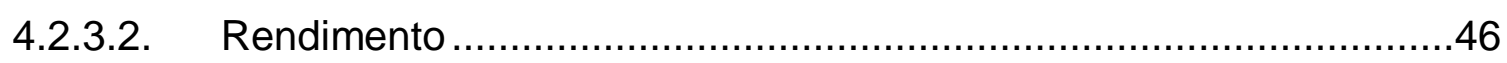

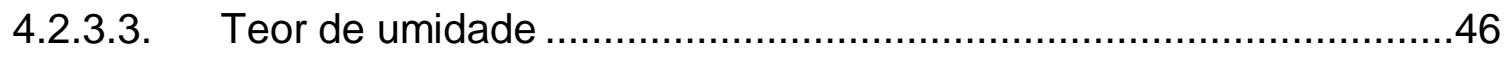

4.2.3.4. Cromatografia em Camada Delgada (CCD) ................................46

4.3. DETERMINAÇÃO DA ATIVIDADE DE INIBIÇÃO SOBRE A TIROSINASE 47

4.3.1. Ensaio da atividade enzimática da tirosinase

4.3.2. Controle positivo para a atividade de inibição sobre a tirosinase 48

4.3.3. Avaliação da influência dos solventes na atividade da tirosinase 49

4.3.4. Determinação da porcentagem de inibição enzimática..................49

4.3.5. Determinação dos valores de $\mathbf{I C}_{50}$ dos extratos padronizados ......50

4.3.6. Análise estatística ...................................................................

4.4. AVALIAÇÃO DO PERFIL CROMATOGRÁFICO POR CROMATOGRAFIA LÍQUIDA DE ALTA EFICIÊNCIA (CLAE-DAD) E DETERMINAÇÃO DOS TEORES DE ÁCIDO CLOROGÊNICO, RUTINA E ISOQUERCITRINA

4.4.1. Validação da metodologia de determinação dos teores de ácido clorogênico, rutina e isoquercitrina no extrato padronizado de $M$. nigra por CLAE-DAD 


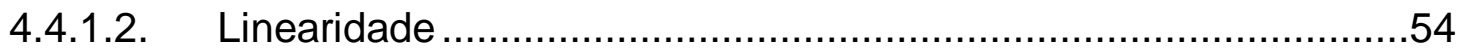

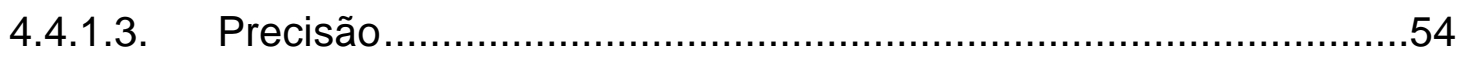

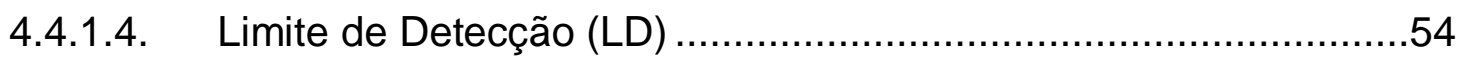

4.4.1.5. Limite de Quantificação (LQ) ................................................55

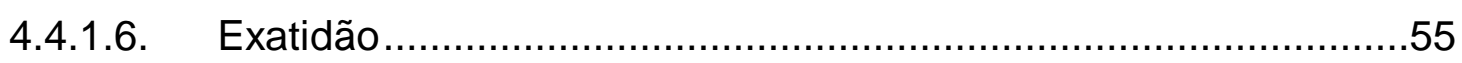

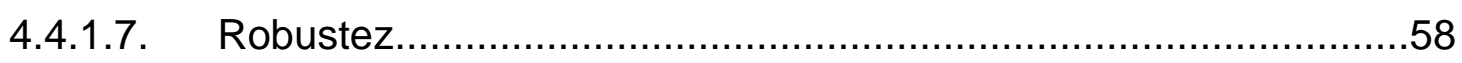

4.4.1.8. Quantificação dos lotes de extrato padronizado de $M$. nigra .........58

4.5. CITOTOXICIDADE DO EXTRATO PADRONIZADO .............................59

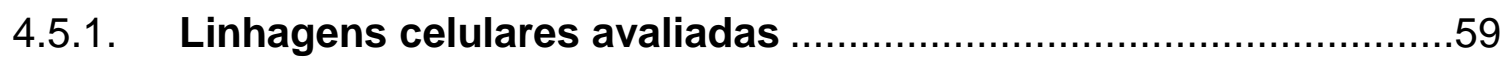

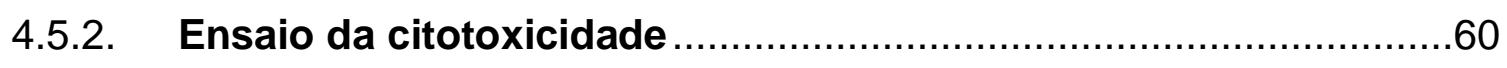

4.5.3. Avaliação da influência dos solventes na citotoxicidade .............61

4.5.4. Avaliação da influência dos extratos vegetais frente ao WST-8....61

4.5.5. Controle de morte celular e viabilidade celular.............................61

4.5.6. Determinação da porcentagem de viabilidade celular...................62

4.5.7. Determinação dos valores de $\mathbf{I C}_{50}$ dos extratos padronizados ......62

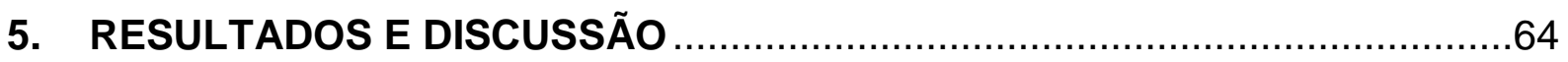

5.1. OBTENÇÃO DO EXTRATO PADRONIZADO DAS FOLHAS DE M. nigra.64 5.1.1. Reprodutibilidade do processo de obtenção do extrato

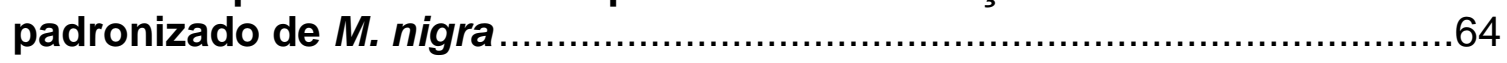

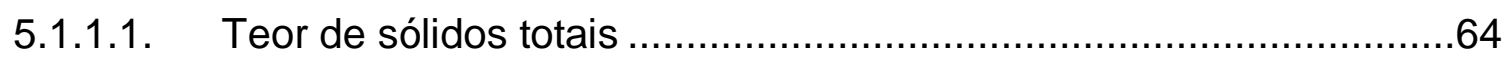

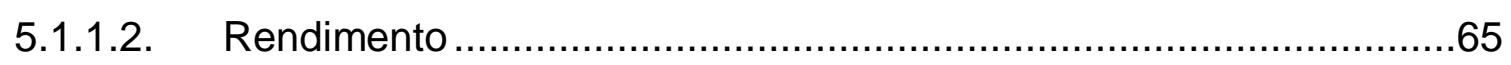

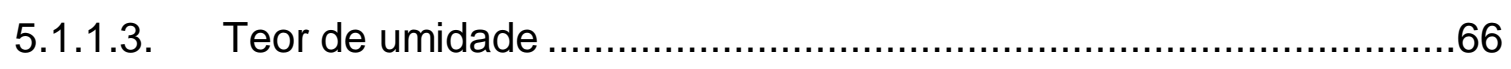

5.1.1.4. Cromatografia em Camada Delgada (CCD) ..................................68

5.2. AVALIAÇÃO DA INIBIÇÃO DA ENZIMA TIROSINASE ..............................71

5.2.1. Extratos padronizados de M. nigra ...............................................

5.3. AVALIAÇÃO DO PERFIL CROMATOGRÁFICO POR CROMATOGRAFIA LÍQUIDA DE ALTA EFICIÊNCIA (CLAE) E DETERMINAÇÃO DOS TEORES DE ÁCIDO CLOROGÊNICO, RUTINA E ISOQUERCITRINA

5.3.1. Validação da metodologia de determinação dos teores de ácido clorogênico, rutina e isoquercitrina no extrato padronizado de $M$. nigra por

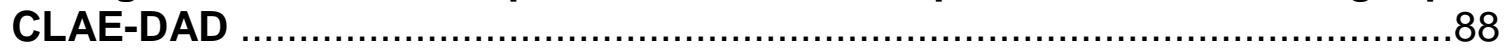

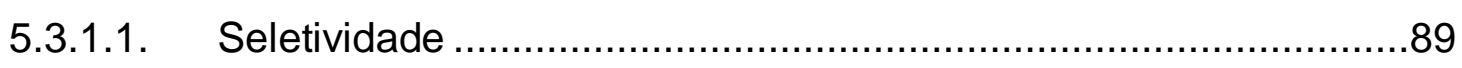

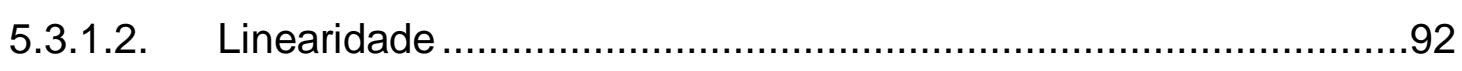

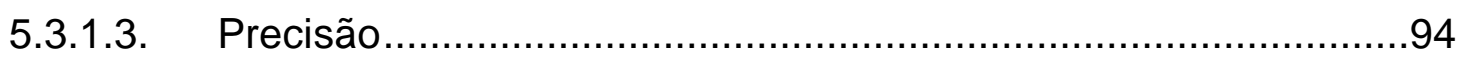

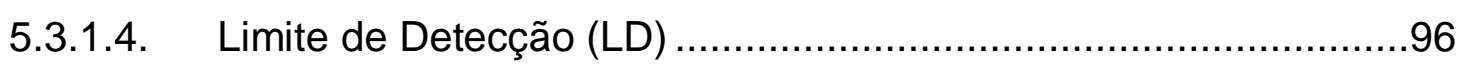

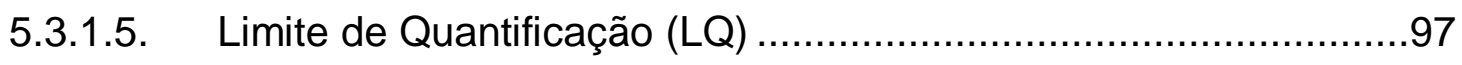

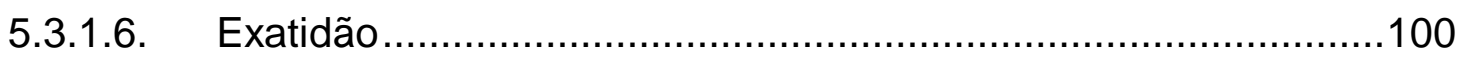

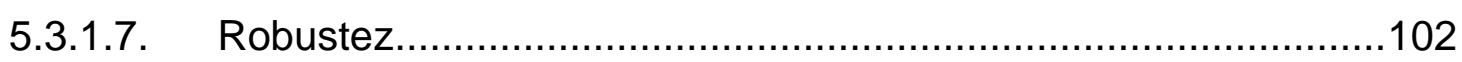


5.3.1.8. Quantificação dos lotes de extrato padronizado de $M$. nigra ......111

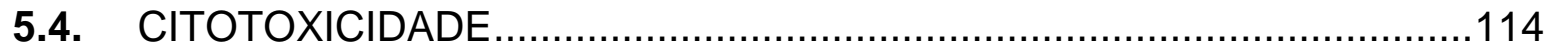

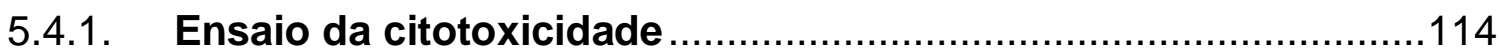

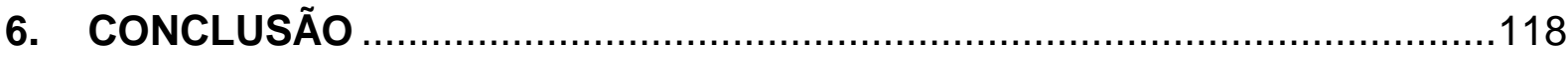

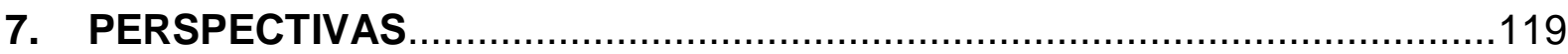

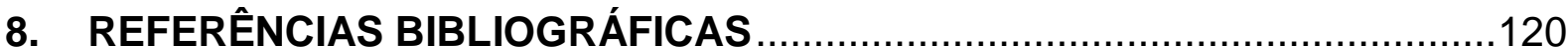




\section{INTRODUÇÃO}

A enzima tirosinase possui um papel essencial na formação do pigmento melanina no corpo de mamíferos, bem como em plantas, microrganismos e fungos. Esta enzima que contém cobre, catalisa duas reações distintas de síntese da melanina: a hidroxilação de tirosina por ação monofenolase e a oxidação de 3,4-dihidroxifenilalanina (L-Dopa) a o-dopaquinona por ação difenolase. O acúmulo de uma quantidade anormal de melanina em diferentes partes da pele como manchas mais pigmentadas denominadas melasmas, sardas e lentigos senis, pode se tornar um problema estético (1).

Por este motivo, o uso de inibidores da tirosinase está se tornando cada vez mais importante na indústria de cosméticos devido aos seus efeitos de clareamento da pele (2). Embora sejam eficazes, a exposição prolongada à hidroquinona, corticoesteroides, ácido kójico e arbutina pode levar a efeitos adversos locais e sistêmicos como ocronose, atrofia e carcinogênese; contudo, diversos extratos de plantas são inibidores da formação de melanina mais potentes que estes agentes despigmentantes tradicionais e não estão associados com a citotoxicidade ou mutagenicidade dos melanócitos (3). Visando minimizar estes efeitos adversos o uso de despigmentantes de origem natural vem ganhando força no mercado mundial de produtos para saúde.

Plantas desempenham um papel importante nas preparações medicinais, tanto preventivas quanto curativa, onde China e India são países líderes na utilização de plantas medicinais, cujas tradições de remédios de plantas datam pelo menos 7000 anos (4). Os fitoterápicos, tratamentos e práticas tradicionais são a principal, e muitas vezes a única, fonte de cuidados de saúde de milhões de pessoas (5).

Espécies do gênero Morus foram domesticadas há milhares de anos e têm sido adaptadas a uma ampla área de zonas tropicais, subtropicais e temperadas da Ásia, Europa, América do Norte, América do Sul e África. Amoreiras têm sido historicamente utilizadas para a produção de folhas utilizadas na sericicultura e suas frutas, raízes e casca têm sido aplicadas na medicina popular (especialmente na medicina Chinesa) para tratar diabetes, hipertensão, anemia e artrite (6). Extratos obtidos de diferentes partes da planta em diferentes espécies do gênero Morus já 
foram descritos como inibidores de tirosinase (7-17). Porém, até o presente momento pouco se sabe sobre a espécie M. nigra.

Morus nigra é utilizada para o tratamento da diabetes, colesterol, problemas cardiovasculares, obesidade e gota (18), possui atividade antioxidante (9, 19-24), atividade antimicrobiana (23), atividade anticâncer (25), ação hepatoprotetora (26) e atividade moluscicida (27). M. nigra possui o maior teor de fenólicos totais e flavonoides dentre as espécies do gênero Morus (28). Algumas partes da planta de M. nigra já foram relatadas como inibidoras da enzima, como seu caule (29) e raíz (30), porém não há relatos de atividade inibidora sobre o extrato de suas folhas.

Devido à sua natureza comestível, fácil acesso e fator econômico, M. nigra pode ser uma boa fonte de teores ativos (26), possuem diversas utilizações terapêuticas oferecidas em diferentes partes da planta incluindo a inibição da enzima tirosinase. Este trabalho teve como objetivo estudar a folha da espécie $M$. nigra quanto à atividade inibitória sobre a enzima tirosinase, bem como a caracterização do perfil cromatográfico de seu extrato padronizado identificando compostos responsáveis pela inibição enzimática e sua viabilidade de incorporação em produtos cosméticos tópicos e medicinais a partir de sua citotoxicidade em linhagens celulares que constituem a epiderme, como os fibroblastos e queratinocitos, a fim de se tornar uma nova opção terapêutica oriunda de fonte natural, que também pode ser utilizada na indústria de alimentos por atuar como um agente antiescurecimento de frutas, legumes e sucos. 


\section{REVISÃO DA LITERATURA}

\subsection{HIPERPIGMENTAÇÃO DA PELE}

Hiperpigmentação é o escurecimento da cor da pele devido à pigmentação excessiva (31). Os melanócitos são células especializadas provenientes de um subconjunto de células-tronco multipotentes na crista neural. Após atingir o seu destino final na camada basal da epiderme, produzem a melanina em organelas relacionadas com lisossomas, chamadas melanossomas, localizados nos dentritos dos melanócitos quando maduros, que são transportados do núcleo para a borda periférica do melanócito que posteriormente são fagocitados para os queratinócitos circundantes transferindo sua melanina (32-35).

Melaninas são biopolímeros essenciais constituídas por unidades monoméricas distintas, as quais estão ligadas por meio de ligações covalentes que podem ser facilmente rompidas por métodos químicos ou por ação de enzimas. Melaninas podem ser classificadas em dois grandes grupos: eumelanina marrom a preto insolúvel e feomelanina amarelo a marrom-avermelhada solúvel em alcali (34). Encontrada em bactérias, fungos, plantas e animais, a melanina é um dos pigmentos mais amplamente distribuídos na natureza (36), que determina a cor da pele humana, cabelos e olhos (35). A principal função da melanina é a proteção contra radiação ultravioleta (UV) (37). A reação mais visível à exposição UV é a formação de melanina e o espessamento da epiderme, um mecanismo de defesa natural destinado a diminuir ainda mais a penetração na camada basal, onde a proliferação está ocorrendo (38). Seu teor na pele é influenciado pela síntese; transporte e degradação de melanina; a espessura do estrato córneo; a proliferação da epiderme e outros fatores que contribuem para a diversidade da cor na pele, e sua síntese depende do número e do nível de diferenciação dos melanócitos, sendo este o maior contribuinte de teor de melanina na pele (39). Há dois grupos de transtornos pigmentares: a presença anormal de pigmentos exógenos ou endógenos na pele e distúrbios da distribuição quantitativa e qualitativa de pigmento normal, o qual inclui hiperpigmentação e hipopigmentação (31). 
Algumas vias de sinalização influenciam a pigmentação. A hiperpigmentação pode ocorrer devido a alguns defeitos genéticos que afetam o desenvolvimento e função de melanócitos jovens, defeitos genéticos envolvidos no metabolismo e estrutura celular e os defeitos genéticos envolvidos na reparação do DNA ou senescência precoce. A hiperpigmentação também ocorre devido ao acúmulo de substâncias e metabólitos pigmentados. Alguns genes estão envolvidos na pigmentação e vias relacionadas como causador de melasma e hiperpigmentação resultante da desregulação da tirosinase. Esta desregulação pode ser causada pela Anemia de Fanconi, pois as células têm níveis reduzidos de tioredoxina, a qual está envolvida na via da pigmentação por regular a função de tirosinase. Níveis reduzidos de tioredoxina aumentam a atividade de tirosinase. Demais indutores da atividade de tirosinase incluem mediadores inflamatórios do ácido araquidônico e deficiência de vitamina B12, consequentemente causando hiperpigmentação (33).

As alterações na pigmentação da pele induzem problemas estéticos significativos com efeito na qualidade de vida $(31,40)$. Algumas condições causadas pela hiperpigmentação incluem sardas induzidas pelos raios UV; melasma exacerbada pela exposição solar, gravidez, uso de contraceptivos orais e alguns antiepilépticos; e hiperpigmentação pós-inflamatória desenvolvida após resolução da acne e dermatite de contato (41). Hiperpigmentação da pele é uma queixa comum entre os pacientes em consultas com dermatologistas (42). Um estudo realizado no Brasil cujo objetivo foi investigar os fatores clínicos associados com melasma e avaliar seu impacto na qualidade de vida de pacientes brasileiros morando na região sul do país, demonstrou que melasma tem um forte impacto sobre o domínio emocional da qualidade de vida, resultante principalmente de sentimentos sobre a aparência da pele, afetando particularmente indivíduos mais velhos que sofrem uma maior duração da doença (43).

Agentes ativos de branqueamento da pele são hoje ainda aplicados como um tratamento a longo prazo e podem causar diversos efeitos adversos, tais como irritação da pele e discromia, tornando importante a busca de uma alternativa eficaz e bem tolerável para reduzir as irregularidades de pigmentação e proteger contra o reaparecimento (44). O composto de despigmentação ideal deve ter um efeito de branqueamento potente, rápido e seletivo sobre melanócitos hiperativados, sem resultar em efeitos colaterais de curto ou longo prazo e remover permanentemente o pigmento indesejável, atuando em um ou mais passos do processo de pigmentação. 
A taxa de produção de melanina e subsequente exposição aos raios UV tanto em células de pigmento cultivadas ou na pele intacta depende da atividade da tirosinase, em vez de simplesmente da proteína tirosinase total (45). As abordagens químicas e instrumentais para tratar hiperpigmentação incluem o controle transcripcional da expressão de tirosinase, glicosilação e maturação de enzimas melanogênicas anterior à síntese de melanina; o controle da atividade (inibição) de tirosinase, inibidores de peroxidase, agentes redutores e sequestradores de espécies reativas de oxigênio (ROS) como o ácido ascórbico e controle póstranscripcional da tirosinase durante a síntese de melanina; e inibição da transferência de melanossoma, dispersão de melanina e aceleração da renovação da pele, inibição da resposta melanogência induzida por inflamação e tratamento a lazer de lesões pigmentadas após a síntese de melanina (46).

\subsection{TIROSINASE}

A enzima tirosinase (EC 1.14.18.1), uma glicoproteína (47) que catalisa a oxidação aeróbica de tirosina para produzir o pigmento melanina, encontra-se amplamente distribuída na natureza (48), onde é encontrada em plantas, insetos, animais marinhos, mamíferos (49), em bactérias como algumas espécies do gênero Streptomyces, incluindo S. antibioticus (50), S. castaneoglobisporus (51) e S. albus (52); espécies do gênero Bacillus, incluindo $B$. thuringiensis (53) e B. megaterium (54) (Figura 1); Aeromonas media (55); Thermomicrobium roseum (56) e Verrucomicrobium spinosum (57). Tirosinase também é encontrada em fungos como as espécies de basidiomicetos Pycnoporus sanguineus, Polyporus arcularius, Lentinus edodes, Agaricus bisporus e Agaricus bisporus; os ascomicetos Podospora anserina e Neurospora crassa; e os deuteromicetos Aspergillus fumigatus e Aspergillus oryzae (58). 


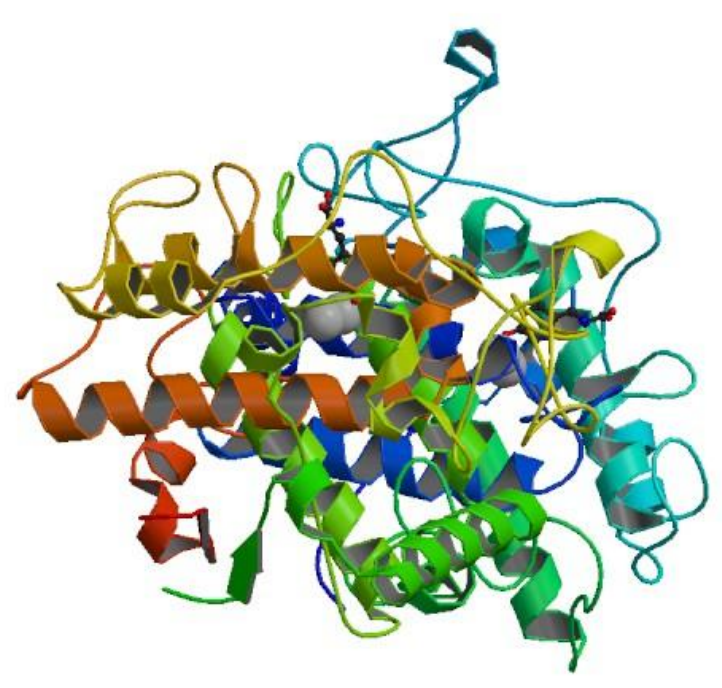

Figura 1 Estrutura cristalográfica da tirosinase de Bacillus megaterium com tirosina no sítio ativo.

Fonte: Goldfeder et al. (2014) (59).

Oxidases de polifenol ou tirosinases (PPO) são enzimas com um centro de cobre dinuclear, cuja estrutura do sítio ativo consiste na ligação do cobre por resíduos de histidina (60) (Figura 2). A oxigenase multi-cobre melhor estudada é a tirosinase, membro das proteínas que contém cobre tipo 3 , cujo sítio ativo pode ser preparado em uma variedade de formas: a forma oxigenada oxytirosinase ( $\left.E_{\text {oxy }}\right)$, que consiste de dois átomos tetragonais $\mathrm{Cu}(\mathrm{II})$; mettirosinase $\left(\mathrm{E}_{\mathrm{met}}\right)$, que também contém dois íons cobre (II) tetragonais; e a desoxitirosinase ( $\left.E_{\text {deoxi }}\right)$, por analogia com a deoxihemocianina, possui uma estrutura bicobre $\left[\mathrm{Cu}^{1}-\mathrm{Cu}{ }^{1}\right](32,36,61)$. Estes três estados de cobre no sítio ativo da tirosinase conduziu a um modelo estrutural proposto para o mecanismo da reação envolvido na o-hidroxilação de monofenóis e oxidação dos difenóis resultantes, que foi baseado na substituição de um ligante associativo no sítio da tirosinase (32). O cobre é um cofator essencial de diversas proteínas envolvidas em reações redox e de ligação e ativação de oxigênio molecular, em que complexos de cobre mononucleares incluem plastocianina, azurina, superóxido dismutase e complexos binucleares incluem hemocianina, tirosinase, e ceruloplasmina (62). O cobre removido da preparação da enzima com 
cianeto produz uma tirosinase relativamente inativa e sua adição restaura a atividade, comprovando que a tirosinase é dependente de cobre para ser ativa (63).

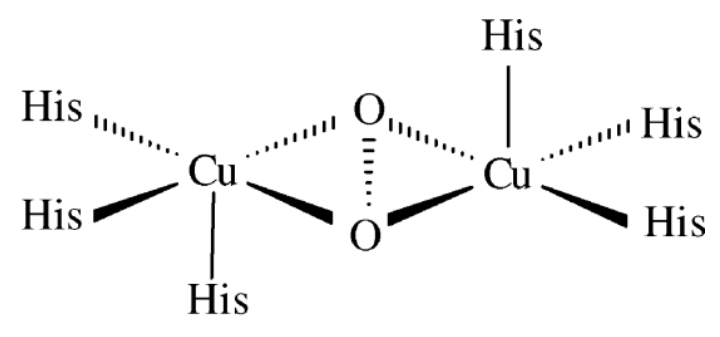

\section{Type-III $\quad \mu-\mathrm{O}_{2}\left[\mathrm{Cu}\left(\mathrm{N}^{\varepsilon}{ }_{\mathrm{His}}\right)_{3}\right]_{2}$}

Figura 2 Modelo pictorial da tirosinase (centros de cobre).

Fonte: Durán et al. (2002) (64).

Os melanossomas contêm tirosinase $(47,65)$, as quais são capazes de introduzir oxigênio numa posição orto à um grupo hidroxila existente em um anel aromático, seguido pela oxidação do difenol para a quinona correspondente, onde o oxigênio molecular é utilizado na reação (60). Sendo assim, esta enzima pode catalisar três reações diferentes na via de biossíntese de melanina: 1) a ohidroxilação de monofenóis (tirosina) à 3,4-di-hidroxifenilalanina (Dopa) chamada atividade cresolase ou "monofenolase"; 2) a oxidação subsequente de dois elétrons dos o-difenóis (Dopa) à o-quinonas reativas (dopaquinona) chamada atividade catecolase ou "difenolase", sendo este processo muito mais rápido do que o primeiro, assim, a hidroxilação de tirosina à L-Dopa é considerado o passo determinante da velocidade; e 3) a oxidação de 5,6-dihidroxiindole (DHI) à indolequinona (IQ) $(36,58,66)$.

Segundo Chang $(67,68)$, a via de Raper-Mason da melanogênese, modificada por Cooksey et al. (1997) (69) e Schallreuter et al. (2008) (70) inicia com a oxidação de tirosina à dopaquinona, catalizada pela tirosinase. A dopaquinona é convertida à Dopa e dopacromo por auto-oxidação. Dopa também é o substrato da tirosinase e é oxidada à dopaquinona novamente pela enzima (Figura 3). 


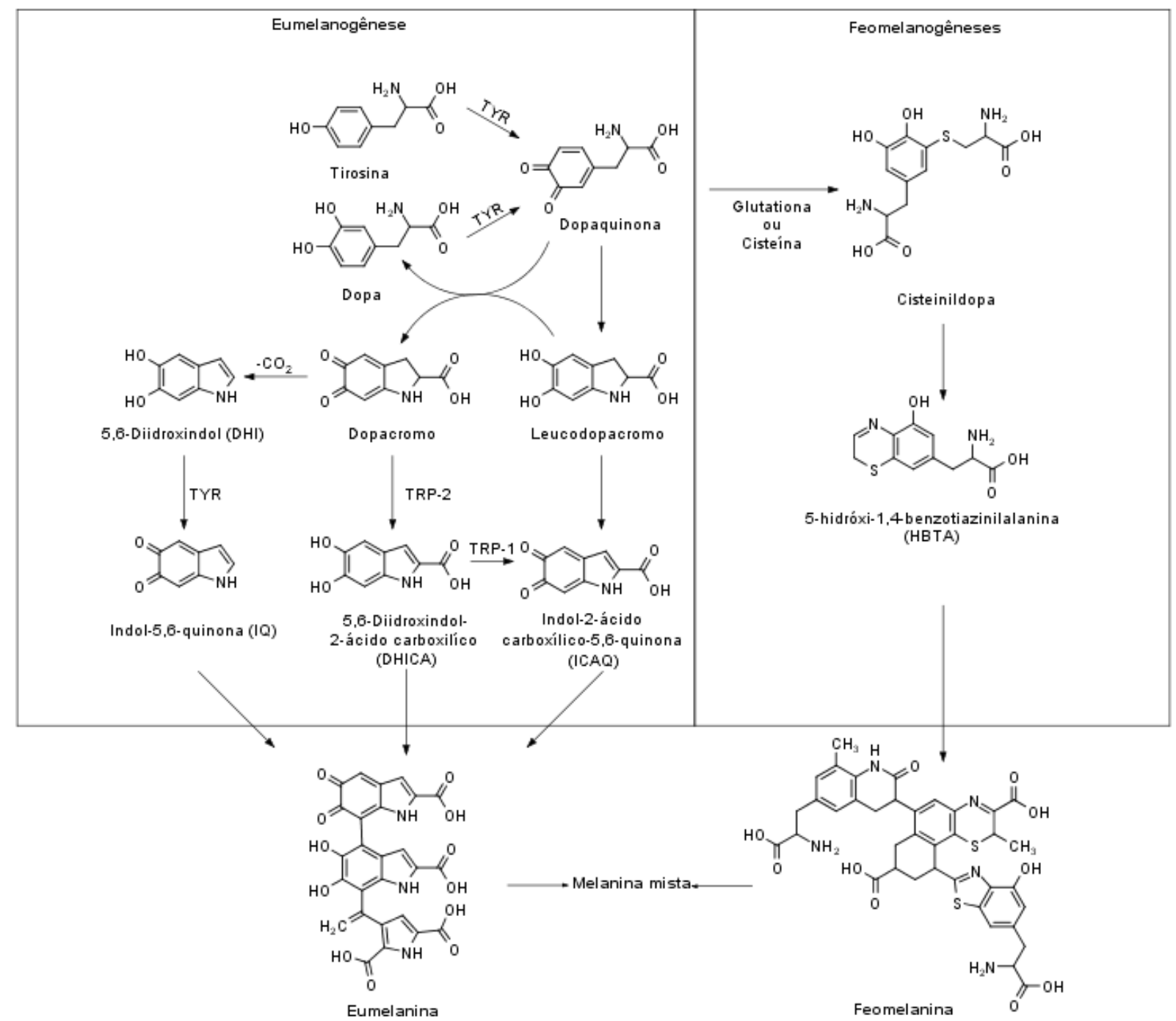

Figura 3 Via de biossíntese de melanina.

Fonte: Chang $(67,68)$.

A via da melanogênese pode ser convenientemente dividida em duas fases: proximal, que consiste na oxidação enzimática de um monofenol (tirosina) e/ou odifenol (L-Dopa), para a sua correspondente o-quinona; e distal, que é representada pelas reações químicas e enzimáticas que ocorrem após a formação de dopacromo e direcionam à síntese de eumelaninas (melaninas marrons à pretas). A disponibilidade de compostos sulfidrilo, glutationa ou cisteína, modificam reações levando à síntese de feomelaninas (melaninas amarelas a marrom-avermelhadas) e tricocromos (32) - uma classe de pequenas moléculas presentes na feomelanina e ausentes em eumelanina (71). Embora três enzimas [tirosinase (TYR), proteína relacionada com a tirosinase 1 (TRP1) e proteína relacionada com a tirosinase 2 
(TRP2)] estejam envolvidas na via da melanogênese, somente a tirosinase é absolutamente necessária para a melanogênese, devido ao seu papel fundamental no processo $(68,72)$, pois TRP1 e TRP2 só atuam após a formação de dopacromo, já a tirosinase está envolvida desde os passos iniciais da biossíntese de melanina, onde sua inibição implicaria na interrupção da orto-hidroxilação de tirosina à Dopa, assim como na interrupção da oxidação desta à dopaquinona.

Além da participação na via da melanogênese, a tirosinase é uma enzima que está envolvida com o escurecimento enzimático de frutas cruas, legumes e bebidas, sendo uma das principais causas de mudanças deletérias na aparência e propriedades organolépticas dos produtos alimentares, perda de qualidade durante a manipulação e processamento pós-colheita, resultando em menor vida útil de prateleira, diminuição do valor no mercado e é, portanto, um grande problema na indústria de alimentos, pois não só prejudica a cor dos produtos, mas também o sabor e o valor nutricional (73). O escurecimento de frutas, vegetais e bebidas resultam a partir da oxidação de compostos fenólicos catalisados por polifenoloxidase (PPO; E.C. 1.14.18.1) em quinonas e a sua subsequente polimerização por ambas as reações enzimáticas e não enzimáticas (74). Desde que o governo dos EUA baniu o uso de sulfitos em frutas e vegetais frescos em 1986, a indústria de alimentos tem procurado agentes antiescurecimento eficazes para controlar a descoloração (75).

\subsection{INIBIDORES DE TIROSINASE}

Apesar das extensas pesquisas sobre agentes de clareamento e hiperpigmentação, os agentes existentes têm limitações em termos de toxicidade elevada, baixa estabilidade, pobre penetração na pele e atividade insuficiente. O uso de inibidores de tirosinase está se tornando cada vez mais importante na indústria de cosméticos devido aos seus efeitos de clareamento da pele e para alcançar este objetivo, muitos produtos já foram produzidos e testados para superar problemas na melanogênese (2).

A inibição da atividade de tirosinase pode ser alcançada através de agentes redutores causadores da redução química da dopaquinona como ácido ascórbico, 
sequestradores de o-dopaquinona como a maioria dos compostos contendo enxofre, substratos de enzimas alternativos tais como alguns compostos fenólicos, inativadores não-específicos de enzimas como ácidos ou bases que desnaturam a enzima, inativadores específicos de tirosinase como substratos suicidas que inativam a enzima irreversivelmente e inibidores específicos de tirosinase que se ligam reversivelmente à enzima e reduzem sua capacidade catalítica (67).

Hoje em dia os despigmentantes mais utilizados pela indústria de cosméticos são ácido kójico, hidroquinona e arbutina. Porém existem problemas relacionados a estes despigmentantes, como o surgimento da dermatite de contato pigmentada (76) e possível poder carcinogênico (77) causado pelo ácido kójico e a fraca inibição de tirosinase por hidroquinona e arbutina (78). Embora a hidroquinona seja considerada como um padrão para tratamento tópico da hiperpigmentação, seu uso tem sido associado à efeitos adversos como irritação da pele, dermatite de contato e ocronose exógena em pessoas de pele escura $(3,79,80)$.

Inibidores de tirosinase naturais são geralmente considerados como sendo livres de efeitos colaterais nocivos e podem ser produzidos a custos razoavelmente baixos, especialmente quando fontes ricas são identificadas (81).

Desoxiarbutina e a-arbutina; aloesina, derivada da aloe; polifenóis, como o ácido elágico; bioflavonoides, como as flavonas, flavonóis, isoflavonas $(6,7,4$ 'triidroxiisoflavona) e flavanonas (hesperidina); isoflavonoides; chalconas; estilbenos; cumarinas; extratos de alcaçuz, Ginseng, Gingko e amora compreendem inibidores de tirosinase de fontes naturais. Benzaldeído e derivados de benzoato, esteróides e lipídios de cadeia longa e inativadores irreversíveis, como o cloreto de cetilpiridínio (82), 3,5-dihidroxifenil decanoato (83) e o álcool p-hidroxibenzil (84), também são classes de inibidores da enzima $(3,85)$.

Entre as substâncias antiescurecimento para a indústria de alimentos, estão cisteína, 4-hexilresorcinol e o ácido kójico, porém estes produtos químicos têm uso comercial limitado devido a problemas de segurança, custo e regulamentação do governo, tornando forte a procura de agentes antiescurecimento a partir de produtos naturais (75). O Ministério da Saúde japonês ordenou que 12 empresas de cosméticos japonesas e estrangeiras parassem de vender produtos que contenham ácido kójico, cujo uso cosmético foi aprovado em 1988 por ser acreditado em reduzir os níveis de melanina na pele, mas os testes em animais têm levantado suspeitas de que ele é um possível carcinogênico (77). Segundo Burnett et al. (2010), os 
dados de sensibilização humana disponíveis consideram segura a aplicação de ácido kójico à uma concentração de $2 \%$, porém a despigmentação da pele de cobaia só foi alcançada à uma concentração de 4 \%, concluindo que sensibilização e branqueamento dérmico não seriam observados na concentração em que este ingrediente é seguro para uso em produtos cosméticos, à $1 \%$ (86).

Compostos como ácidos p-alcoxibenzoico (87), N-benzilbenzamidas (88), ácidos alquilbenzoicos (89), benzaldeídos 4-substituídos (73), 2,'4,'6'triidroxichalconas (90) são alguns exemplos de inibidores de tirosinase.

$\mathrm{Na}$ literatura, estudos descrevem compostos fitoquímicos isolados e extratos de diferentes partes de plantas inibidoras de tirosinase, como o extrato da semente de Sapindus mukorossi (Sapindaceae) (91), derivados hidroxicinâmico dos grãos de café (92), compostos isolados e extrato bruto metanólico e diclorometano de Marrubium velutinum e Marrubium cylleneum (Lamiaceae) (93), compostos isolados de Amberboa ramosa (Compositae) (94), compostos isolados das sementes de Pimpinella anisum L. e Cuminum cyminum L. (Umbelliferae) $(95,96)$, flavonoides das flores secas de Heterotheca inuloides Cass (Compositae) (97), um flavonol isolado das pétalas das flores de Crocus sativus L. (Iridaceae) (98), o complexo de flavonoide das flores de Sophora japonica L. (Fabaceae) (99), extratos das folhas de Macaranga gigantea, Macaranga pruinosa, Macaranga tanarius e Macaranga triloba (Euphorbiaceae) (100), extrato das sementes de Mangifera indica L. (Anacardiaceae) (101) e compostos isolados das folhas de Aloe arborescens var. natalensis Berger (Xanthorrhoeaceae) (102). Outros estudos realizaram screening de plantas inibidoras de tirosinase, como Masuda et al. (2005) que investigaram extratos metanólicos de 39 espécies de plantas do litoral da ilha de Iriomote, Okinawa, Japão (12) e Souza et al. (2012) que investigou 33 extratos brutos de 12 espécies de plantas do Cerrado (103).

Um estudo realizado por Baurin et al. (2002), cujo objetivo foi realizar a triagem preliminar de algumas plantas tropicais para atividade anti-tirosinase, testou 67 plantas coletadas no Brasil pertencentes a 38 famílias, em que o extrato de Morus alba foi utilizado como controle positivo com a maior porcentagem de inibição enzimática entre as demais plantas estudadas (104). Recentemente, Ya et al. (2015), fizeram uma triagem de 44 plantas para atividades inibidora da tirosinase e antioxidante, em que Morus alba foi utilizada como controle positivo por exibir elevada inibição sobre a enzima (105). Espécies do gênero Morus são 
frequentemente associadas a potentes fontes naturais inibidoras de tirosinase, tanto como planta de estudo, como controle positivo de inibição da tirosinase.

\subsection{O GÊNERO Morus}

Moraceae é uma família das angiospermas que compreende cerca de 40 gêneros e 1400 espécies (106). Amoreiras (gênero Morus) é uma planta economicamente importante usada para sericicultura, uma vez que é a única planta que serve como alimento para o bicho-da-seda domesticado, Bombyx mori (107), de cujo casulo se extrai fibras para a indústria têxtil (108). Têm sido amplamente cultivadas em vários países de sericicultura asiáticos (por exemplo, China, Coreia, Japão e assim por diante) e adaptadas a diversas zonas climáticas da Europa, Américas e África (15).

Originária da Ásia, o gênero Morus foi introduzido no Brasil (108) durante o período colonial. A importação de algumas amoreiras é atribuída a D. João VI, que iniciou o plantio junto ao Jardim Botânico do Rio de Janeiro, no começo do século XIX (109). O plantio das amoreiras (M. nigra) para alimentar o bicho-da-seda visando a produção de seda ocorreu em 1838 no Jardim Botânico do Rio de Janeiro (110). Em 1848 ocorreu a introdução da sericicultura no território brasileiro no Estado do Rio de Janeiro e, em 1922, na cidade de Campinas-SP. A partir da década de 30, a sericicultura tornou-se uma importante atividade para a agroindústria brasileira e, atualmente, o Estado do Paraná é o maior produtor nacional de casulos verdes de bicho da seda (111). Hoje, amora é amplamente conhecida e é comum em pomares, em ambientes recreacionais rurais e jardins. Seu fruto é apreciado por ser de consumo direto e para fazer geléia, no entanto, o cultivo de amoreira comercial ocorre apenas nas regiões em que está associada a sericicultura. Até 1998, a área de amoreiras no Brasil abrangia cerca de 38.000 hectares, em que o estado do Paraná era a maior concentração dessa área (32.400 hectares), seguidos pela porção oeste do estado de São Paulo (4.600 hectares) e por áreas menores nos estados de Goiás, Mato Grosso do Sul, Minas Gerais e Santa Catarina, segundo a Associação Brasileira de Fiações de Seda (112). 
Em 2002, o Ministério da Saúde chinês declarou que o fruto e folha de amoreira não são apenas alimentos, mas medicamentos, e a casca da raíz (Cortex Mori albae) e galho são alimentos saudáveis, especialmente a raíz, que foi amplamente utilizada na prescrição popular da Medicina Tradicional Chinesa. Estudos farmacológicos provam as propriedades anti-inflamatória, hipoglicêmica, hipotensora, anticarcinogênica e antimicrobiana dos extratos aquosos ou metanólicos do Cortex Mori; e os extratos de clorofórmio possuem propriedades antiinflamatória e anti-asmática $(6,15)$. Espécies do gênero Morus possuem atividade antidiabética, antimicrobiana, antioxidante, imunonutritivas, anticâncer, neuroprotetora, hepatoprotetora, ansiolítica, antidepressiva e na interrupção de aterosclerose $(113,114)$. O extrato etanólico de folhas de $M$. alba $L$. tem um efeito vasodilatador em ratos e coelhos, provavelmente devido à um aumento de óxido nítrico nos níveis séricos (115).

Os extratos de espécies de Morus, que tem sido conhecida como uma planta rica em polifenóis e utilizada como um agente terapêutico natural não tóxico, também apresentam um elevado potencial em aplicações como agentes de branqueamento da pele devido a muitos inibidores potentes da tirosinase serem isolados a partir de diferentes partes da planta (85). Oxiresveratrol, um composto natural encontrado particularmente em Morus alba exibiu um efeito inibitório potente na atividade dopa oxidase da tirosinase (116). Os extratos etanólicos do galho e da casca da raiz de Morus alba L. mostraram ter atividade contra a tirosinase através da presença de maclurina, rutina, isoquercitrina, resveratrol e morina (9). Oxiresveratrol e oxiresveratrol-3-O-glicosídeo, produtos da hidrólise enzimática de mulberrosídeo A isolado do extrato etanólico da raiz de Morus alba, suprimem a expressão de enzimas melanogênicas tirosinase, proteína-1 relacionada à tirosinase e fator de transcrição microftalmia, sendo o efeito anti-melanogênese maior com oxiresveratrol, seguido de oxiresveratrol-3-O-glicosídeo e por fim, mulberrosídeo A (7). Mulberrosídeo F, obtido do extrato metanólico das folhas secas de Morus alba, também é eficaz na inibição da enzima (8). Mulberrosídeo A obtido de uma solução alcóolica (80 \%) extraída da casca dos galhos de Morus multicaulis Perr. cultivada inibiu as atividades monofenolase e difenolase da tirosinase (15).

Uma chalcona bioativa obtida a partir do fracionamento do extrato solúvel metanólico da haste de Morus australis e seus análogos inibem a atividade da tirosinase (11). O extrato do caule de Morus australis contém um inibidor de 
tirosinase conhecido, oxiresveratrol, e o extrato de sua raiz apresentou um novo composto, austraona A, junto com outros 21 compostos conhecidos isolados, dentre os quais moracenina $D$, sanggenon $T$, e kuwanon $O$, exibiram atividades inibitórias de tirosinase mais potentes que do ácido kójico (10). Em um screening de 50 plantas, o extrato etanólico (80 \%) de Morus bombycis Koidzumi foi o segundo mais potente a inibir a tirosinase humana depois de $V$. bracteatum Thunberg, mais potentes que a arbutina, inibindo também a tirosinase fúngica, a qual não foi inibida por V. bracteatum Thunberg (117).

Investigação fitoquímica do caule de Morus notabilis conduziu ao isolamento e caracterização de 10 compostos de 2-arilbenzofuranos, incluindo dois novos compostos (16). Dos constituintes do extrato etanólico das folhas de Morus yunnanensis, duas novas flavanas, morusiunasinas $E$ e $F$ e duas flavanas conhecidas demonstraram efeitos inibitórios potentes em tirosinase, superiores ao ácido kójico (17). Doze polifenóis do extrato metanólico (95 \%) das raízes de Morus Ihou inibiram a tirosinase fúngica, entre eles quatro flavanonas, quatro flavonas e quatro fenilbenzofuranos, em que um destes foi identificado como um novo composto, derivado de moracina (14) bem como nas cascas do seu caule pelas flavonas mormina, ciclomorusina, morusina, kuwanon C e norartocarpetina (13).

\subsubsection{Morus nigra Linné}

Encontrada na África, América do Sul e na Ásia, M. nigra Linné. tem sido utilizada na medicina Unani - medicina tradicional Perso-árabe - como antitússico, diurético, expectorante e hipotensivo, possui vasta gama de utilizações medicinais e pode ser utilizada como medicamento individualmente ou um composto de medicamento para tratar diferentes doenças. Os compostos fenólicos de $M$. nigra têm propriedades antioxidante e antibacteriana (27). A planta foi trazida para a região do Vale do São Francisco - Brasil por imigrantes japoneses, adaptando-se bem às condições de clima e solo, onde essa espécie é conhecida popularmente como "amora-miúra" e o chá de suas folhas é bastante utilizado pela população local para o tratamento de diabetes, colesterol, problemas cardiovasculares, obesidade e gota (18). 
Amoras pretas (conhecidas como amoras medicinais na região Uygur) são frutas suculentas com cor extraordinária e um sabor único, ligeiramente ácido, e são cultivadas principalmente pelo seu valor medicinal, em vez de frutos comestíveis, no sul de Xinjiang da China $(6,118)$. Os frutos de $M$. nigra são utilizados como medicamento na Turquia, em particular a região oriental da Anatólia, devido ao alto teor de fenólicos e flavonoides (28) e para tratar lesões na boca (6).

A pequena flor de $M$. nigra é aclamídea, não possui pétalas nem sépalas. São unissexuadas e pistiladas, que porta somente estruturas sexuais femininas. Seu fruto é composto, onde várias flores unem-se na maturação para formar uma única estrutura, tratada como uma só fruta, demonstrados na Figura 4 (119).

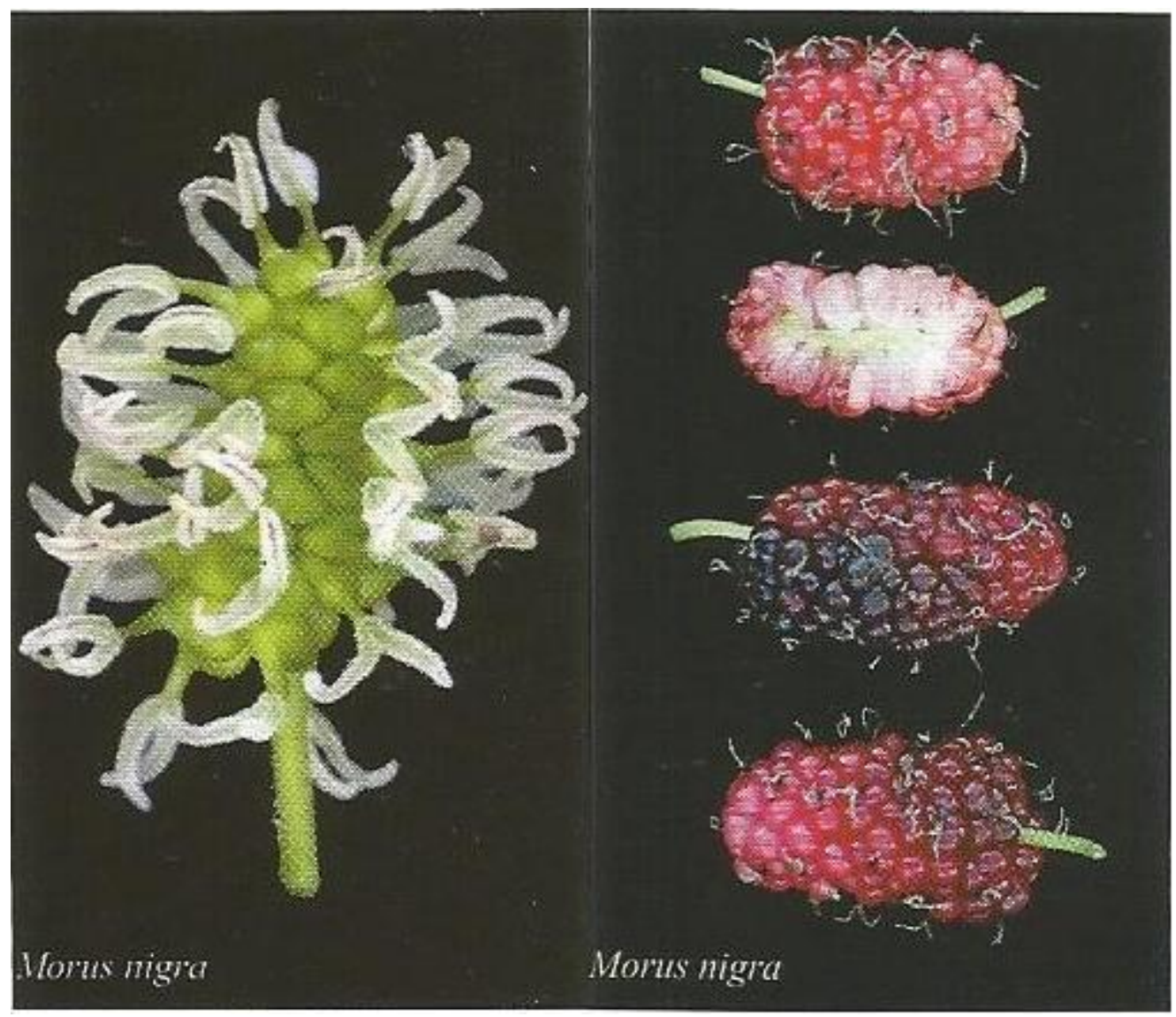

Figura 4 Flores e frutos de M. nigra.

Fonte: Golçalves et al. (2007) (119).

Um estudo farmacobotânico conduzido por Padilha et al. (2010) caracterizou macroscopicamente as folhas de amoreira-preta, M. nigra L.. Estas atingem 16,0 x $8,0 \mathrm{~cm}$, sua margem é serrilhada, apresenta base arredondada e ápice acuminado, 
com nervação peninérvia. Seu limbo é simples, íntegro, de superfície rugosa e forma oval com coloração verde escuro na face ventral e coloração verde claro na face dorsal, flexível e membranácea, como demonstrado na Figura 5 (120).

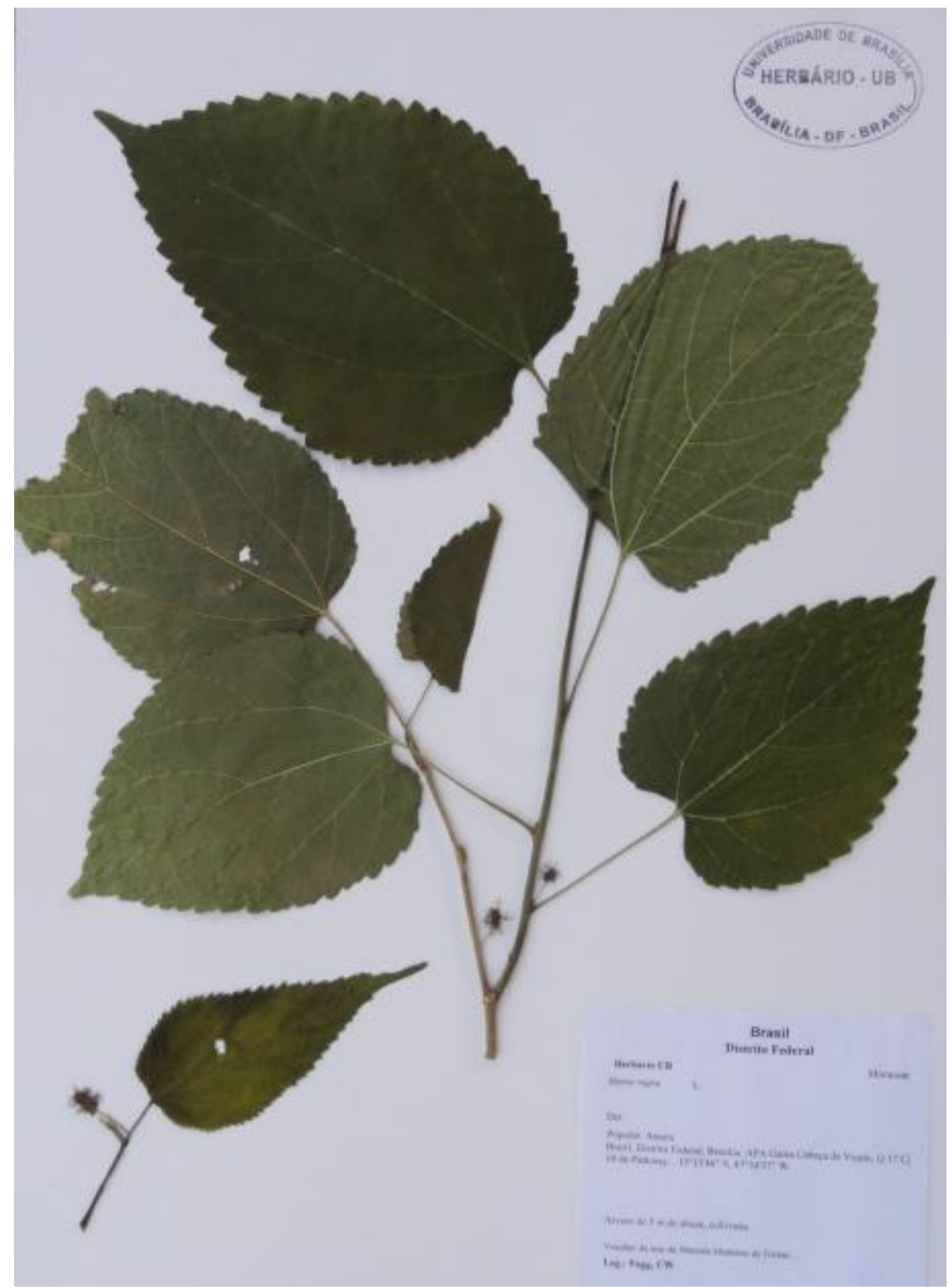

Figura 5 Exsicata de M. nigra depositada no Herbário da Universidade de Brasília, voucher Fagg CW 2302. 
Estudos comparativos conduzidos na Turquia por Ercisli et al. (2007, 2010), em que a composição química das frutas de amora branca (Morus alba), vermelha (Morus rubra) e preta (Morus nigra) foi investigada, os maiores teores de fenólicos totais e flavonoides foram observados em amora preta (1422 mg equivalentes de ácido gálico/100 g de matéria fresca e $276 \mathrm{mg}$ equivalentes de quercetina/100 g de matéria fresca) (28). Ao avaliar o conteúdo fitoquímico de alguns genótipos de amoras negras ( $M$. nigra) e amoras roxas ( $M$. rubra) crescidas na Turquia, foi observado que os genótipos de amoras negras possuem maior teor bioativo que genótipos de amoras roxas, devido ao seu teor de fenólicos totais, antocianinas totais, e atividade antioxidante superior à das amoras roxas (20).

Similarmente, Arfan et al. (2012) demonstraram que os extratos metanólicos e acetônicos livres de açúcar dos frutos de $M$. nigra apresentaram teor fenólico total e atividade antioxidante total superior aos extratos dos frutos de $M$. alba (19). Hassimotto et al. (2005) afirmaram que os frutos de $M$. nigra têm a maior atividade antioxidante dentre 14 frutas, legumes e polpas testados, tanto para o método de oxidação lipossomal como para o sistema de branqueamento de $\beta$-caroteno (21). Naderi et al. (2004) afirmaram que os frutos de $M$. nigra têm ação protetora contra dano peroxidativo à biomembranas e biomoléculas devido a sua atividade antioxidante de inibição da glicosilação da hemoglobina induzida pela glicose, e pela inibição da hemólise de eritrócitos humanos pelos extratos hidroalcóolico e polifenol (24).

Um estudo conduzido por Jiang e Nie (2015) mostrou que frutos de M. nigra possuem o maior conteúdo de ácido ascórbico reduzido, acidez titulável, Ferro e é a mais rica em termos de flavonoides totais e antocianinas monoméricas totais em um estudo comparativo entre a amora negra, branca ( $M$. alba L.) e Russa ( $M$. alba var. tatarica L.) crescidas na província Xinjiang da China (118). M. nigra Linn. foi uma das cinco principais variedades que continha altos teores de antocianina no seu suco e suas frutas, sendo assim um recurso potencial para plantas com quantidades elevadas de antocianina e pode servir como recurso genético para melhoramento em sua composição de nutrientes (121).

Um estudo conduzido por Song et al. (2009) demonstrou que o suco de $M$. alba Linn. e M. nigra Linn. continha mais 1-desoxinojirimicina (DNJ) que as demais espécies estudadas, e para as folhas de amoreira as variedades $M$. atropurpurea Roxb. e M. nigra Linn. estavam entre o mais alto teor de DNJ. Ao comparar espécies 
diferentes, afirmaram que $M$. nigra Linn. continha mais DNJ do que outras espécies, sendo este um dos principais alcalóides de piperidina polihidroxilados em amoras (121), descritos como inibidores de glucosidase, cujo potencial uso inclui tratamento de infecções virais, crescimento tumoral, metástases, diabetes, doença de Gaucher e osteoartrite (122).

Nove compostos foram identificados por Wang et al. (2007) nas cascas de $M$. nigra, entre eles o ácido ursólico e $\beta$-sitosterol, e sete primeiramente isolados ácido olcancólico, apigenina, ciclocommunol, morusina, ciclomorusina, kuwanon C e daucosterol (123). A investigação da fração acetato de etila do extrato acetona e etanólico da casca do caule e o extrato metanólico do tronco da madeira de $M$. nigra por Mazimba et al. (2011) produziu oxiresveratrol, moracina M, quatro flavonoides isoprenilados - ciclomorusina, morusina, kuwanon C e seu derivado -, dois triterpenos - ácido betulínico, acetato de $\alpha$-amirina - e uma saponina esteroidal $\beta$ sitosterol-3-O- $\beta$-D-glicosídeo, em que os isolados fenólicos apresentaram moderada atividade de eliminação de radicais DPPH comparada ao ácido ascórbico e alguns compostos apresentaram atividade antimicrobiana contra Staphylococcus aureus, Bacillus subtilis, Micrococus flavus, Streptococcus faecalis, Salmonella abony e Pseudomonas aeruginosa (23).

Qadir et al. (2014) estudaram a atividade anticâncer dos extratos das folhas de $M$. nigra, em que $100 \mu \mathrm{g} / \mathrm{mL}$ do extrato metanólico (70 \%) inibiu 89,5 $\pm 2,0 \%$ das células de câncer cervical humano (HeLa) $\left(\mathrm{IC}_{50} 56,0 \pm 1,6 \mu \mathrm{g} / \mathrm{mL}\right)$, enquanto nesta concentração o extrato $n$-hexano das folhas de $M$. nigra inibiu apenas 41,2 $\pm 0,8 \%$ ( IC $\left._{50} 185,9 \pm 8,3 \mu \mathrm{g} / \mathrm{mL}\right)$, confirmando sua atividade anticâncer (25). Ao realizar uma triagem fitoquímica, Mallhi et al. (2014) confirmaram a presença de importantes fitoconstituíntes nos extratos metanólicos (70\%) das folhas de $M$. nigra como fenóis, flanovóides, saponinas e alcalóides, em que a análise de flavonoides por CLAE em fluxo isocrático revelou a presença de luteolina, quercetina e isorhamnetina. $O$ estudo deste extrato em ratos com intoxicação induzida por paracetamol revelou a ação hepatoprotetora de $M$. nigra administrada a 250 e 500 mg/kg, com redução das enzimas hepáticas (ALT, AST, ALP) e bilirrubina total comparáveis ao controle silimarina. O potencial hepatoprotetor de $M$. nigra pode ocorrer devido à presença dos flavonoides, fenóis e saponinas, em que flavonoides tem comprovada contribuição na ação hepatoprotetora (26). Hanif e Singh (2012) confirmaram a 
atividade moluscicida dos frutos, casca e folhas pulverizadas de $M$. nigra contra o caramujo de água doce Lymnaea acuminata, hospedeiro intermediário dos trematódeos Fasciola hepatica e F. gigantica causadores da doeça helmíntica fasciolíase, em que o controle da população do caramujo é uma das maiores ferramentas para reduzir a incidência desta doença no gado e nos humanos (27).

O extrato etanólico (95\%) da raíz de $M$. nigra revelou a presença de 28 compostos conhecidos e um novo composto, 5'-geranil-5,7,2',4'-tetrahidroxiflavona, dos quais nove mostraram melhores atividades inibitórias da tirosinase que o ácido

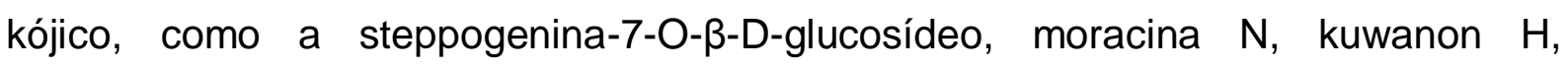
mulberrofurano $G$, oxiresveratrol-2-O- $\beta$-D-glucopiranosídeo, oxiresveratrol-3'-O- $\beta$-Dglucopiranosídeo, 2,4,2',4'-tetrahidroxichalcona e morachalcona A. Estes dois últimos obtiveram valores de $\mathrm{IC}_{50} 757$ vezes e 328 vezes menores que o do ácido kójico, respectivamente, 0 que sugere um grande potencial para 0 seu desenvolvimento como inibidores da tirosinase naturais eficazes (30). A 2,4,2',4'tetraidroxi-3-(3-metil-2-butenil)-chalcona do extrato etanólico (95\%) da haste de $M$. nigra agiu como um inibidor competitivo à tirosinase fúngica, sendo mais potente que o ácido kójico, inibindo também a biossíntese de melanina em células de melanoma B16 sem citotoxicidade significativa (29).

A folha de $M$. nigra pode servir como um cosmético adequado para clareamento da pele já que as demais espécies do gênero Morus possuem, em distintas porções de sua planta, diversos compostos que inibem a enzima de interesse. Até a presente data não foram encontrados relatos na literatura acerca da inibição de tirosinase pelo extrato etanólico das folhas de $M$. nigra, o que faz deste trabalho inovador, por sugerir uma nova fonte natural branqueadora.

Além disso, os compêndios nacionais carecem de informações padronizadas acerca do gênero Morus e suas espécies, pois não constam monografias na $1^{\text {a }}$ edição do Formulário de Fitoterápicos da Farmacopeia Brasileira (2011) e na 5 $5^{\mathbf{a}}$ edição da Farmacopeia Brasileira (2010). A monografia de amora - fruto composto de Morus nigra - consta apenas na primeira edição da Farmacopeia Brasileira, em que seus frutos são caracterizados e seu emprego oficinal é descrito como suco de amora (124). Morus sp é uma das 71 espécies vegetais da Relação Nacional de Plantas Medicinais de Interesse ao Sistema Único de Saúde (Renisus) elaborada pelo Ministério da Saúde (MS) em 2013. A finalidade da lista é orientar estudos e pesquisas que possam subsidiar a elaboração da relação de fitoterápicos 
disponíveis para uso da população, em que Morus apresenta potencial para geração de produtos de interesse ao SUS (125).

\subsection{PADRONIZAÇÃO DE EXTRATOS VEGETAIS}

Fitoquímicos são compostos que ocorrem naturalmente nas plantas, responsáveis pela sua cor, sabor e cheiro, fazendo parte de um mecanismo de defesa natural contra doenças (126). Fitoconstituintes puros e extratos de plantas oferecem oportunidades ilimitadas para o desenvolvimento de novos medicamentos devido à sua disponibilidade de diversidade química (4). Atualmente, produtos naturais derivados de plantas desempenham um papel importante para curar diversas condições de doença, em que as espécies de plantas estão sendo estudadas persistentemente para a identificação de novos agentes terapêuticos (127). Os medicamentos fitoterápicos estão em grande demanda nos países desenvolvidos, bem como os países em desenvolvimento para assistência médica primária por causa de suas amplas atividades biológicas, margens de segurança mais elevadas e menores custos. Os desafios mais importantes enfrentados por essas formulações surgem devido a ausência de padronização completa, pois os medicamentos fitoterápicos são preparados a partir de materiais de origem vegetal que são propensos a contaminação, deterioração e variação na composição química, portanto, o controle da qualidade de fitoterápicos oferece uma série de problemas (128).

As plantas são inevitavelmente "irregulares", pois sua composição pode ser influenciada por fatores como origem, crescimento, colheita, secagem e condições de armazenamento, sendo assim, o controle da qualidade inicia a partir da matériaprima, em que o material vegetal é o fator mais importante na produção de produtos medicinais botânicos (129). Estas abordagens regulatórias para fitoterápicos têm por objetivo proteger a saúde dos consumidores, garantindo que os medicamentos são seguros e de alta qualidade (5).

Padronização é uma ferramenta no processo de controle da qualidade. Para medicamentos fitoterápicos, é o processo de prescrever de um conjunto de normas ou características inerentes, parâmetros constantes, valores qualitativos e 
quantitativos definitivos que carregam uma garantia de qualidade, eficácia, segurança e reprodutibilidade, em concordância com as normas técnicas. A descrição de um conjunto de características exibidas pelo fitoterápico é originada pela experimentação e observações que trabalham normas específicas (130).

A Resolução - RDC nำ26, de 13 de maio de 2014 (131) regulamenta o registro de Medicamentos Fitoterápicos e o registro e a notificação de Produtos Tradicionais Fitoterápicos. Para serem disponibilizados ao consumo, estes terão que apresentar requisitos semelhantes de qualidade (132).

Segundo a Instrução Normativa $N^{\circ} 4$, de 18 de junho de 2014 (132), que determina a publicação do Guia de orientação para registro de Medicamento Fitoterápico e registro e notificação de Produto Tradicional Fitoterápico, os métodos utilizados no controle de qualidade destes devem estar presentes em farmacopeias reconhecidas ou serem validados. No caso de utilização de farmacopeias reconhecidas pela Anvisa, deve-se realizar os testes constantes nela como obrigatórios. Quando não forem utilizadas farmacopeias reconhecidas pela Anvisa, será exigida a descrição detalhada de todos os métodos utilizados no controle de qualidade, e os métodos analíticos devem estar validados de acordo com o Guia Para Validação de Métodos Analíticos e Bioanalíticos, publicado pela Anvisa como Resolução - RE no 899, de 29 de maio de 2003. Seu objetivo é demonstrar que o método é apropriado para a finalidade pretendida, determinando qualitativa, semiquantitativa e/ou quantitativamente fármacos e outras substâncias em produtos farmacêuticos (133).

Desta forma, entendemos que devido as particularidades relacionadas à obtenção de produtos naturais e a necessidade de atender as normas vigentes na legislação sanitária, a padronização dos extratos vegetais torna-se essencial para produção e registro de um fitoterápico seguro e eficaz. 


\section{OBJETIVOS}

Objetivo geral: Avaliar a inibição da enzima tirosinase pelo extrato padronizado das folhas de M. nigra.

Para atingir este objetivo, foram traçados os seguintes objetivos específicos:

- Obter o extrato padronizado da folhas de M. nigra;

- Avaliar a inibição da enzima tirosinase pelo extrato padronizado de M. nigra;

- Determinar a concentração capaz de inibir $50 \%$ da atividade máxima $\left(\mathrm{IC}_{50}\right)$ da enzima de interesse pelo extrato testado;

- Identificar os compostos fitoquímicos majoritários presentes no extrato padronizado das folhas de M. nigra;

- Validar a metodologia analítica para quantificar os compostos majoritários de interesse presentes no extato padronizado; e

- Avaliar a citotoxicidade do extrato padronizado frente às células de fibroblastos, queratinócitos e melanomas. 


\section{MATERIAIS E MÉTODOS}

\subsection{PREPARO DAS SOLUÇÕES}

- Reagente anisaldeído solução A

Anisaldeído em ácido acético

$2 \%$

- Reagente anisaldeído solução B

Solução etanólica de $\mathrm{H}_{2} \mathrm{SO}_{4}$

$20 \%$

- Reagente Natural Products-Polietilenoglicol (NP-PEG) solução A Solução metanólica de difenilboriloxietilamina

- Reagente Natural Products-Polietilenoglicol (NP-PEG) solução B Solução etanólica de polietilenoglicol-4000 (PEG)

- Padrão de ácido clorogênico, rutina e isoquercitrina

Soluções de estoque padrão $1 \mathrm{mg} / \mathrm{mL}$ de ácido clorogênico, rutina e isoquercitrina (Sigma-Aldrich) foram preparadas pela diluição de $10 \mathrm{mg}$ de cada padrão com 10 $\mathrm{mL}$ de metanol em um balão volumétrico. Uma solução de estoque mista de padrões de $100 \mu \mathrm{g} / \mathrm{mL}$ foi preparada a partir de $1 \mathrm{~mL}$ de cada padrão $(1 \mathrm{mg} / \mathrm{mL})$ com $10 \mathrm{~mL}$ de metanol em um balão volumétrico, seguido do preparo de diluições de soluções padrão mistas em balão volumétrico de $10 \mathrm{~mL}$ obtendo diferentes concentrações $(0,075-10,0 \mu \mathrm{g} / \mathrm{mL})$.

- Tampão fosfato de sódio $0,2 \mathrm{M} \mathrm{pH} \mathrm{6,5}$

Fosfato de sódio monobásico monohidratado $\mathrm{NaH}_{2} \mathrm{PO}_{4} \cdot \mathrm{H}_{2} \mathrm{O}$ (Vetec) $\quad 27,6 \mathrm{~g}$ Água destilada q.s.p. $\quad 1000 \mathrm{~mL}$

Fosfato de sódio dibásico dodecahidratado $\mathrm{Na}_{2} \mathrm{HPO}_{4} \cdot 12 \mathrm{H}_{2} \mathrm{O}$ (Vetec) $\quad 71,63 \mathrm{~g}$ Água destilada q.s.p. $\quad 1000 \mathrm{~mL}$ 
Fosfato de sódio bibásico anidro (Dinâmica)

$28,41 \mathrm{~g}$

Água ultrapura q.s.p.

$1000 \mathrm{~mL}$

Fosfato de sódio monobásico monohidratado 0,2 M

$685 \mathrm{~mL}$

Fosfato de sódio dibásico dodecahidratado $0,2 \mathrm{M}$

$315 \mathrm{~mL}$

- Tampão fosfato de sódio $50 \mathrm{mM} \mathrm{pH} \mathrm{6,5}$

Tampão fosfato de sódio $0,2 \mathrm{M} \mathrm{pH} \mathrm{6,5}$

$250 \mathrm{~mL}$

Água destilada

$1000 \mathrm{~mL}$

- Solução de tirosinase $250 \mathrm{U} / \mathrm{mL}$

Tirosinase fúngica $10 \mathrm{KU} / \mathrm{mL}$ (25 KU Sigma-Aldrich)

$250 \mu \mathrm{L}$

Tampão fosfato de sódio $50 \mathrm{mM} \mathrm{pH} \mathrm{6,5} \mathrm{q.s.p.}$

$10 \mathrm{~mL}$

- Solução de L-Tirosina 2 mM

L-Tirosina (Sigma-Aldrich)

$18,0 \mathrm{mg}$

Tampão fosfato de sódio 50 mM pH 6,5 q.s.p.

$50,0 \mathrm{~mL}$

- Solução de ácido kójico - Controle positivo

Ácido kójico (Sigma-Aldrich)

$20,0 \mathrm{mg}$

Tampão fosfato de sódio $50 \mathrm{mM} \mathrm{pH} \mathrm{6,5}$

$1,0 \mathrm{~mL}$

- Solução de extrato vegetal para ensaio da tirosinase

Extrato padronizado $M$. nigra lotes $1 \mathrm{~A}, 2 \mathrm{~A}, 3 \mathrm{~A}, 4 \mathrm{~A}$ e $5 \mathrm{~A}$

20,0 mg

Metanol

$1,0 \mathrm{~mL}$

A concentração da solução-mãe de cada extrato foi ajustada para uma concentração final no ensaio de $1 \mathrm{mg} / \mathrm{mL}$.

- Solução de extrato vegetal para ensaio da citotoxicidade

Extrato padronizado $M$. nigra lote $4 \mathrm{~A}$

$40,0 \mathrm{mg}$

Metanol

$1,0 \mathrm{~mL}$ 
Adicionar $500 \mu \mathrm{L}$ desta solução à $9,5 \mathrm{~mL}$ de DMEM incolor $5,0 \%$, ajustando a concentração final no ensaio de $2 \mathrm{mg} / \mathrm{mL}$.

- Dodecil Sulfato de Sódio (SDS) $10,0 \%$

SDS

DMEM incolor 5,0 \%

Adicionar $100 \mu \mathrm{L}$ desta solução à $900 \mu \mathrm{L}$ de DMEM incolor $5,0 \%$

- Meio de Eagle modificado por Dulbecco (DMEM) incolor 5,0\%

Glicose

$0,045 \mathrm{~g}$

Água para injetáveis

$10 \mathrm{~mL}$

Soro Fetal Bovino

$2,5 \mathrm{~mL}$

Aminoácido não-essencial

$500 \mu \mathrm{L}$

Bicarbonato de sódio

$500 \mu \mathrm{L}$

Piruvato

$500 \mu \mathrm{L}$

L-glutamina

$20 \mu \mathrm{L}$

DMEM 1x (Gibco) q.s.p

$50 \mathrm{~mL}$

Ajustar pH entre 7,0 e 7,4 com tampão HEPES (ácido 4-(2-hidroxietil)-1piperazinoetanossulfônico) $1 \mathrm{M}$.

\subsection{PADRONIZAÇÃO DO EXTRATO DE $M$. nigra}

\subsubsection{Obtenção do material botânico}

As folhas de M. nigra foram coletadas manualmente em 24 de março de 2014 às 10 horas da manhã em Brasília, Distrito Federal sob coordenadas de GPS 15.56.274S 47.57.689W. A árvore de M. nigra, cultivada, sem adubo e irrigação, foi plantada em época de chuvas, mantida em pleno sol com pouco sombreamento advindo de árvores próximas. No momento da coleta o tempo estava nublado, mas não choveu no dia. A temperatura máxima na data da coleta foi de $23,2^{\circ} \mathrm{C}$ e a 
temperatura mínima de $16,9^{\circ} \mathrm{C}$ (134). A planta se encontrava em fase de desenvolvimento vegetativo adulto, pois apareceram flores duas semanas após a poda.

Uma exsicata do material botânico foi depositada no Herbário da Universidade de Brasília, voucher Fagg CW 2302 (Figura 5).

O acesso ao patrimônio genético foi autorizado pelo CNPq em 2014, processo 010337/2014-8 referente ao projeto "Levantamento etnobotânico e biomonitoramento químico de plantas do Cerrado e Pantanal com atividade farmacológica" que inclui espécies do gênero Morus (validade: 30/04/2014 à 30/04/2016), sob a responsabilidade da Professora Pérola Magalhães, Universidade de Brasília.

\subsubsection{Obtenção do extrato padronizado das folhas de $M$. nigra}

As folhas foram secas por um processo natural seguido de processo artificial. Inicialmente, as folhas foram secas ao ar livre, na sombra, sob uma área coberta, sendo necessário de 3 a 4 dias para secagem por motivo de umidade do ar devido à época das chuvas, em que a umidade relativa média na data da coleta foi de $90 \%$ (134). Para realizar o processo de secagem artificial, as folhas de $M$. nigra coletadas foram divididas em três lotes e secas em estufa à temperatura de $40^{\circ} \mathrm{C}$ até atingir faixa adequada de umidade de 8 a $14 \%$ para produção de medicamentos Fitoterápicos, segundo o Guia de orientação para registro de Medicamento Fitoterápico e registro e notificação de Produto Tradicional Fitoterápico (132). O teor de umidade das folhas foi determinado através da perda por dessecação (135) pelo analisador de umidade por infravermelho (Gehaka modelo IV2000, São Paulo - SP, Brasil) em amostras de $1 \mathrm{~g}$ de folhas, realizados em triplicata, até atingir umidade de $9 \%$.

Após processo de secagem, as folhas foram pulverizadas em moinho de facas e tamisadas em agitador de peneiras para análises granulométricas eletromagnético (Bertel, Caieiras-SP, Brasil), por 1 minuto, com reostato ajustado ao nível 5 de vibração, padronizando o tamanho do material botânico pulverizado entre 63 e $500 \mathrm{~mm} / \mu \mathrm{m}$ (tamanho Mesh 230-35). Foi realizada maceração passiva a frio, 
que manteve a droga, convenientemente pulverizada, na proporção $1: 5 \mathrm{~m} / \mathrm{v}$, em contato com álcool etílico $95 \%$ - preparado a partir de álcool etílico absoluto em adição de água destilada com auxílio de um alcômetro - com agitação manual diária, por dez dias consecutivos, de acordo com o Formulário de Fitoterápicos da Farmacopeia Brasileira que estipula que o período do processo de maceração deverá ser de, no mínimo, sete dias consecutivos (136). Para a reprodutibilidade do processo de obtenção do extrato padronizado de $M$. nigra, o material botânico foi dividido em cinco lotes iguais, de $210 \mathrm{~g}$ de folhas pulverizadas cada, a serem extraídas com $1050 \mathrm{~mL}$ de álcool etílico $95 \%$. O processo foi realizado à temperatura ambiente e foram utilizados recipientes de vidro envolvidos em papel alumínio bem vedados, de modo à não permitir contato com a luz para evitar que as propriedades fitoquímicas fossem perdidas com a luminosidade. Após o tempo de maceração a mistura foi vertida em um papel de filtro e os extratos filtrados acondicionados em frascos âmbar. O resíduo restante no papel de filtro foi lavado aos poucos com quantidade suficiente (q.s.) do líquido extrator, álcool etílico $95 \%$, de forma a obter o volume inicial, de $1050 \mathrm{~mL}$.

Os extratos foram então concentrados em evaporador rotativo (Heidolph Instruments, Schwabach - Alemanha) com refrigerador acoplado (Heidolph Instruments, MX07R-20-HD2E, Schwabach - Alemanha) e bomba de vácuo (Heidolph Instruments D-91126, Schwabach - Alemanha), sob rotação de até 150 rpm à temperatura de $40^{\circ} \mathrm{C}$ e transferidos para tubos de centrífuga de $50 \mathrm{~mL}$, e mantidos em banho Maria de bocas (Quimis Aparelhos Científicos, Q334M-28, Diadema-SP, Brasil) a $40^{\circ} \mathrm{C}$ até secagem do solvente residual. Posteriormente, os tubos foram congelados à $-80^{\circ} \mathrm{C}$ para liofilização (liofilizador K105 Liotop, Liobras, São Carlos - SP, Brasil) do extrato. O período de liofilização foi de 17 horas para cada lote, obtendo-se assim os extratos secos das folhas de M. nigra.

\subsubsection{Reprodutibilidade do processo de obtenção do extrato padronizado de M. nigra}

Para avaliar a reprodutibilidade do método de extração, 5 (cinco) extrações diferentes foram processadas, seguindo as condições pré-estabelecidas, como 
demonstra a Figura 6. Os parâmetros teor de sólidos totais prévio à liofilização do extrato, rendimento, teor de umidade após a liofilização do extrato e perfil cromatográfico em Cromatografia em Camada Delgada (CCD) foram avaliados.

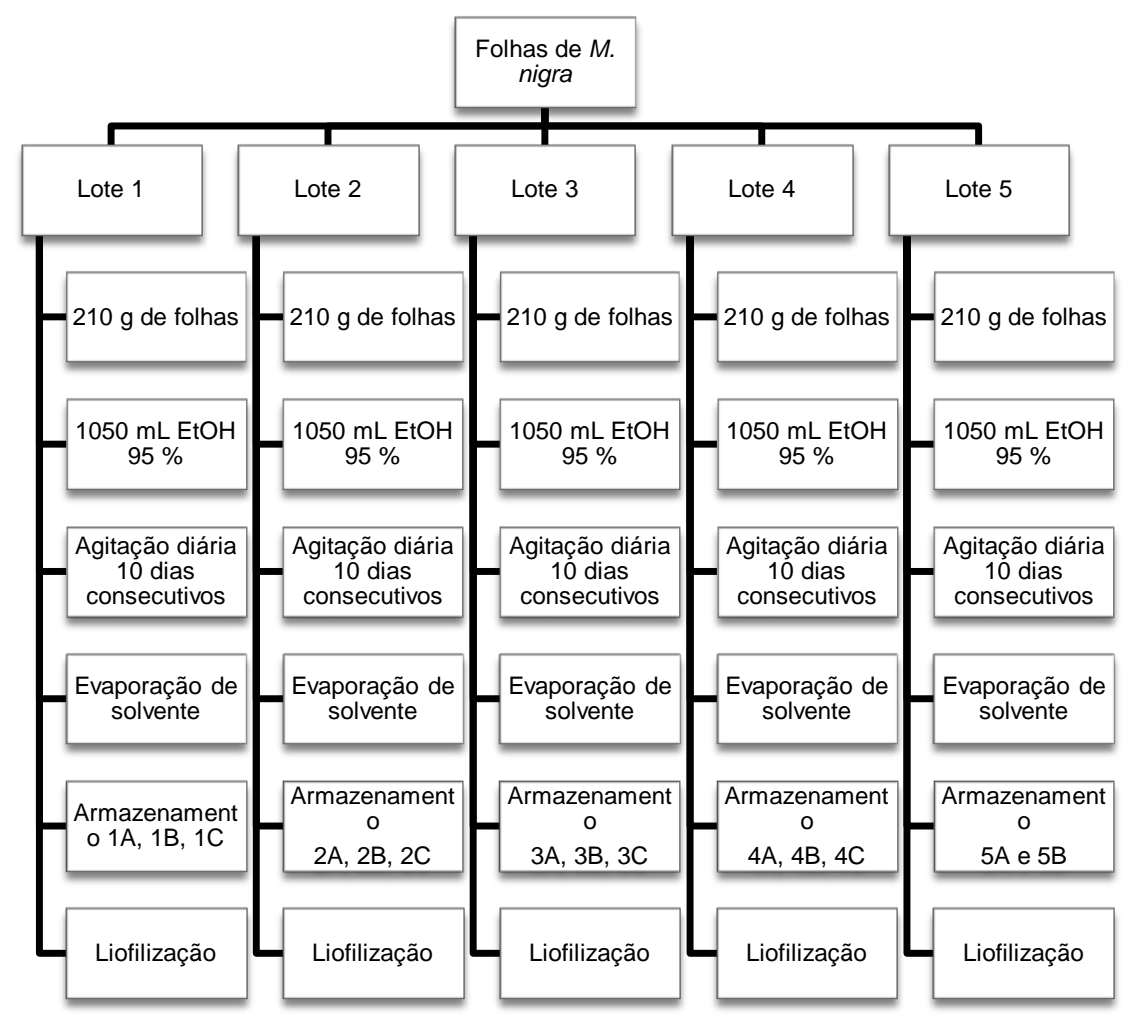

Figura 6 Esquema de divisão dos lotes e obtenção do extrato padronizado de $M$. nigra.

O extratos fluidos de $M$. nigra de diferentes lotes foram armazenados em diferentes tubos de centrífuga de acordo com o volume obtido após concentração em evaporador rotativo, resultando em dois tubos para o lote 5 ( $A$ e $B$ ) e três tubos para os lotes 1, 2, 3 e 4 (A, B e C).

\subsubsection{Teor de sólidos totais}

O teor de sólidos totais do extrato etanólico filtrado das folhas de M. nigra foi determinado pelo analisador de umidade por infravermelho (Gehaka modelo IV2000, São Paulo - SP, Brasil) em amostras de $2 \mathrm{~mL}$ de extrato etanólico filtrado de cada lote, anterior ao processo de concentração e liofilização. O aparelho foi pré-aquecido 
a $100^{\circ} \mathrm{C}$ e ajustado na função auto-dry. Todos os experimentos foram realizados em triplicata.

\subsubsection{Rendimento}

O rendimento de um processo extrativo visa determinar, em porcentagem, a massa de extrato padronizado obtida em relação à massa de folhas utilizadas no início do processo.

Os rendimentos da obtenção dos extratos das folhas de $M$. nigra foram determinados para os cinco lotes através da seguinte formula:

$$
\text { Rendimento }(\%)=\frac{\text { peso seco do lote }(g) \times 100}{\text { massa de folhas pulverizadas }(g)}
$$

Onde a massa de folhas pulverizadas para cada lote foi de $210 \mathrm{~g}$.

\subsubsection{Teor de umidade}

O teor de umidade do extrato das folhas de $M$. nigra foi determinado através da perda por dessecação em balança por infravermelho (135) (Gehaka modelo IV2000, São Paulo - SP, Brasil) em amostras de $1 \mathrm{~g}$ de extrato padronizado de cada lote, após a liofilização. O aparelho foi pré-aquecido a $100^{\circ} \mathrm{C}$ e ajustado na função auto-dry. Todos os experimentos foram realizados em triplicata.

\subsubsection{Cromatografia em Camada Delgada (CCD)}

Amostras de $10 \mathrm{mg}$ dos extratos padronizados de cada tubo foram pesadas em balança analítica (Shimadzu, modelo AY220, São Paulo - SP, Brasil) e estas 
foram solubilizadas em $500 \mu \mathrm{L}$ de metanol $(20 \mathrm{mg} / \mathrm{mL})$. A fase estacionária utilizada foi a placa de sílica gel com matriz de óxido de alumínio (Sigma-Aldrich, Steinheim Alemanha).

A fase móvel da primeira cromatoplaca foi composta de uma mistura de hexano e acetato de etila (7:3) para revelação com o reagente anisaldeído. Primeiramente foi borrifada a solução A e em seguida foi borrifada a solução B. A cromatoplaca foi então aquecida e visualizada.

Para a detecção de flavonoides e demais substâncias fenólicas na amostra, a fase móvel da segunda cromatoplaca foi composta de uma mistura de acetato de etila-ácido fórmico-ácido acético glacial-água (100:11:11:26) e a cromatoplaca foi revelada com o reagente Natural Product - Polietilenoglicol (NP-PEG) (137). Primeiramente foi borrifada a solução $A$ e em seguida foi borrifada a solução $B$. A cromatoplaca foi então visualizada sob luz ultravioleta $(\lambda=365 \mathrm{~nm})$ em câmara UV (Prodicil, Curitiba - PR, Brasil). Uma amostra mista dos padrões ácido clorogênico, rutina e isoquercitrina $(0,33 \mu \mathrm{g} / \mathrm{mL})$ foi adicionada à cromatoplaca para comparação. Os valores do fator de retenção (RF), foram então calculados.

\subsection{DETERMINAÇÃO DA ATIVIDADE DE INIBIÇÃO SOBRE A TIROSINASE}

\subsubsection{Ensaio da atividade enzimática da tirosinase}

De acordo com trabalhos anteriores do grupo de pesquisa, extratos brutos aquoso, etanólico e hexânico das folhas de $M$. nigra foram avaliados frente à inibição da enzima tirosinase por Souza (2011) (138), em que somente o extrato etanólico obteve elevada inibição sobre a enzima em comparação com os extratos aquoso e hexânico, os quais obtiveram nenhuma ou baixa atividade inibitória, respectivamente. A partir destes resultados, o etanol $95 \%$ foi escolhido como o solvente extrator para seguimento do estudo. 
O extrato padronizado obtido foi testado frente a diferentes solventes para a realização dos ensaios, tais como DMSO (5\%) em tampão fosfato de sódio $50 \mathrm{mM}$ $\mathrm{pH} 6,5$, etanol $95 \%$ e metanol. O solvente que apresentou melhor solubilidade do extrato padronizado foi o metanol, sendo este o solvente de escolha para a realização dos ensaios.

Os ensaios da atividade enzimática da tirosinase foram realizados segundo o método utilizado por Khatib et al. (2005) (139), com algumas modificações. Em microplacas de 96 poços foram adicionados $60 \mu \mathrm{L}$ de solução tampão fosfato de sódio $50 \mathrm{mM}(\mathrm{pH}$ 6,5), $10 \mu \mathrm{L}$ da solução de extrato dos lotes 1A, 2A, 3A, 4A e 5A (20 $\mathrm{mg} / \mathrm{mL}$ ) e $30 \mu \mathrm{L}$ de solução de tirosinase $250 \mathrm{U} / \mathrm{mL}$, em triplicata. Após 5 minutos a $25^{\circ} \mathrm{C}$, foram adicionados $100 \mu \mathrm{L}$ de solução de L-tirosina. Após 20 minutos de reação a $25^{\circ} \mathrm{C}$, a absorbância foi medida a $450 \mathrm{~nm}$ em leitor automático de microplacas (Beckman Coulter, modelo DTX 800, Lagerhausstrasse - Austria). Para o branco do extrato foram preparadas amostras contendo solução tampão fosfato de

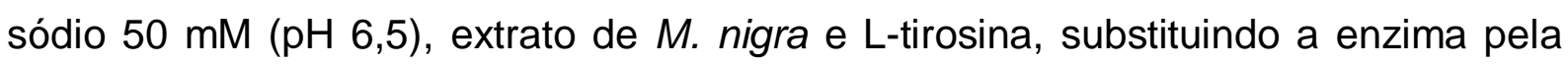
solução tampão utilizada no ensaio, mantendo o mesmo volume final em todos os poços $(200 \mu \mathrm{L})$, com a finalidade de eliminar variações relacionadas à absorbância da coloração característica do extrato vegetal e variações relacionadas à absorbância da coloração de L-tirosina.

\subsubsection{Controle positivo para a atividade de inibição sobre a tirosinase}

O ácido kójico (Sigma-Aldrich, USA) foi utilizado como controle positivo de inibição da tirosinase. A curva dose-resposta para ácido kójico foi construída com concentrações variando entre 1000 e $0,49 \mu \mathrm{g} / \mathrm{mL}$, em triplicata. A solução denominada branco do controle positivo foi preparada substituindo a enzima pela solução tampão fosfato de sódio $50 \mathrm{mM}(\mathrm{pH} 6,5)$. 


\subsubsection{Avaliação da influência dos solventes na atividade da tirosinase}

Os solventes utilizados para extrair as folhas de $M$. nigra e solubilizar as amostras de diferentes lotes do extrato padronizado de $M$. nigra foram avaliados frente à atividade da tirosinase nas mesmas condições do experimento para a determinação da atividade enzimática, substituindo o volume de amostra pelo solvente testado. O álcool etílico 95 \% utilizado no processo extrativo, bem como o metanol utilizado na diluição do extrato de $M$. nigra para a realização do presente ensaio, foram testados como controle para assegurar que estes solventes, a uma concentração de 5,0 \% do volume total no poço (200 $\mu \mathrm{L})$, não apresentassem atividade inibidora da tirosinase, assegurando a não-interferência nos resultados de inibição enzimática.

\subsubsection{Determinação da porcentagem de inibição enzimática}

As porcentagens de inibição sobre a tirosinase foram calculadas comparandose a absorbância das amostras (ensaio contendo extrato + enzima + substrato) com a do controle da enzima (ensaio contendo tampão + enzima + substrato), em que este foi preparado a partir de $70 \mu \mathrm{L}$ de tampão fosfato de sódio $50 \mathrm{mM}(\mathrm{pH} 6,5), 30$ $\mu \mathrm{L}$ de solução de tirosinase $250 \mathrm{U} / \mathrm{mL}$ e $100 \mu \mathrm{L}$ de solução de L-tirosina, respeitando o mesmo volume final de todos os poços, de $200 \mu \mathrm{L}$, e mantendo as mesmas condições do ensaio. Os valores correspondentes à absorbância do controle da enzima forneceram o referencial da atividade máxima da enzima utilizada para a realização dos experimentos, ou seja, refere-se à capacidade máxima da enzima para a formação dos produtos a partir dos seus substratos, tendo sido considerada a atividade da enzima igual a $100 \%$. Dessa forma as porcentagens de inibição das amostras foram calculadas de acordo com a seguinte equação:

$$
\operatorname{Inibição~}(\%)=100-\frac{[(C-A) \times 100]}{C}
$$


Onde C representa a absorbância do controle da enzima, subtraída do branco do substrato e A representa a absorbância da amostra subtraída do branco do extrato (extrato vegetal + substrato + tampão).

\subsubsection{Determinação dos valores de $\mathrm{IC}_{50}$ dos extratos padronizados}

Os valores de $\mathrm{IC}_{50}$ foram determinados através da construção de curvas dose-resposta para cada um dos cinco lotes de extrato padronizado de $M$. nigra, o controle positivo ácido kójico e os polifenóis ácido clorogênico e rutina. As soluções vegetais e do controle positivo para o ensaio foram preparadas por diluição seriada da solução mãe (extrato vegetal ou controle positivo) de concentração inicial de 1 $\mathrm{mg} / \mathrm{mL}$ até concentração final de $0,49 \mu \mathrm{g} / \mathrm{mL}(1000 \mu \mathrm{g} / \mathrm{mL} ; 500 \mu \mathrm{g} / \mathrm{mL} ; 250 \mu \mathrm{g} / \mathrm{mL}$; $125 \mu \mathrm{g} / \mathrm{mL} ; 62,5 \mu \mathrm{g} / \mathrm{mL} ; 31,25 \mu \mathrm{g} / \mathrm{mL} ; 15,63 \mu \mathrm{g} / \mathrm{mL} ; 7,81 \mu \mathrm{g} / \mathrm{mL} ; 3,91 \mu \mathrm{g} / \mathrm{mL} ; 1,95$ $\mu \mathrm{g} / \mathrm{mL} ; 0,98 \mu \mathrm{g} / \mathrm{mL} ; 0,49 \mu \mathrm{g} / \mathrm{mL})$. Cada diluição foi analisada em triplicata e a porcentagem de inibição foi calculada.

A curva de inibição foi obtida construindo um gráfico com a porcentagem (\%) de inibição versus o logaritmo da concentração do inibidor (extrato vegetal ou controle positivo). Os parâmetros de regressão não-linear foram traçados para cada curva e os valores de $\mathrm{IC}_{50}$ foram obtidos utilizando o software GraphPad Prism 5.0®.

\subsubsection{Análise estatística}

Cada concentração de cada amostra foi analisada em triplicata e os resultados obtidos foram apresentados na forma de média ponderada, com os respectivos desvios padrão. Os valores encontrados foram comparados ao controle com o uso de um teste paramétrico $\mathrm{t}$ de Student bicaudal, utilizando como hipótese nula a diferença entre as médias, ou seja, o teste busca identificar se as médias encontradas para a amostra e para o controle são significativamente diferentes entre 
o controle e a amostra. O limite de significância para todas as análises estatísticas foi de $p<0,05$, resultando, portanto em um intervalo de confiança de $95 \%$.

4.4. AVALIAÇÃO DO PERFIL CROMATOGRÁFICO POR CROMATOGRAFIA LÍQUIDA DE ALTA EFICIÊNCIA (CLAE-DAD) E DETERMINAÇÃO DOS TEORES DE ÁCIDO CLOROGÊNICO, RUTINA E ISOQUERCITRINA

De acordo com trabalhos anteriores do grupo de pesquisa, um método CLAEDAD para determinação de rutina no extrato de Erythroxylum suberosum foi desenvolvido e validado por Leite et al. (2014) (140), no qual a avaliação do perfil cromatográfico do extrato padronizado das folhas de $M$. nigra foi baseada, com modificações. O tempo de corrida foi reduzido para 45 minutos e uma amostra de 5 $\mathrm{mg} / \mathrm{mL}$ do extrato padronizado de $M$. nigra foi analisada sob diferentes fluxos $(0,3-$ $0,8 \mathrm{~mL} / \mathrm{min})$. Posteriormente, o método foi avaliado frente a diferentes concentrações de amostra ( $1 \mathrm{mg} / \mathrm{mL}, 2 \mathrm{mg} / \mathrm{mL}$ e $4 \mathrm{mg} / \mathrm{mL})$.

Condições cromatográficas: as análises foram realizadas em cromatógrafo líquido de alta eficiência (CLAE) Dionex UltiMate 3000 e detector DAD-3000, contando com bomba DGP-3600SD, injetor WPS-3000 SplitLoop, forno para coluna TCC-3200, mantido a $25^{\circ} \mathrm{C}$. A coluna utilizada foi PurospherStar RP C18 (150 x 4,6 mm, $5 \mu \mathrm{m}$, Merck, Germany) (Part. $\mathrm{n}^{\circ}$ 945681), acoplada a uma pré-coluna de mesmas características ( $4 \times 4$; tamanho de partícula $5 \mu \mathrm{m}$, Merck, Germany). $\mathrm{O}$ detector foi ajustado para coletar dados em 280, 330 e 354 nm. A fase móvel foi constituída com solução de ácido fosfórico 1 \% (Bomba $A)$ e acetonitrila (Bomba $C$ ), sendo o gradiente de eluição demonstrado na Tabela 1. O fluxo de fase móvel foi de $0,5 \mathrm{~mL} / \mathrm{min}$ e o volume de injeção de $10 \mu \mathrm{L}$. Os dados foram adquiridos por Chromeleon® 7 software (versão 7.1.2.1541 Thermo Fisher Scientific). Os solventes ácido fosfórico e acetonitrila utilizados na fase móvel e o metanol utilizado para diluir o extrato foram adquiridos pela Tedia (Fairfield, OH, EUA). A água utilizada para preparo da fase móvel foi purificada em um sistema Milli-Q-plus System (Millipore, Bedforte, MA, EUA). Todos os solventes utilizados na fase móvel foram filtrados em 
membrana filtrante de fluoreto de polivinilideno (PVDF) 0,22 $\mu \mathrm{m}, 47 \mathrm{~mm}$ (Merck Millipore) com aparato de filtração (Sigma-Aldrich, St. Louis, MO - EUA) e desareados por 20 minutos em sonicador (Bransonic modelo 1510E-DTH, Danbury, CT - EUA). O aparato CLAE conta com uma raque para solventes com desaerador integrado. Para todos os ensaios, a coluna foi equilibrada por um perídodo de duas horas nas condições de fluxo e temperatura a serem analisados.

Tabela 1 - Gradiente de eluição na análise por CLAE-DAD

\begin{tabular}{ccc}
\hline Tempo (min) & Bomba A (\%) & Bomba C (\%) \\
\hline 0 & 90 & 10 \\
40 & 70 & 30 \\
45 & 90 & 10
\end{tabular}

Eluentes: Bomba A (água acidificada com $1 \%$ de solução de ácido fosfórico $85 \%$ ), Bomba C (acetonitrila).

Para o preparo da amostra foram pesados $10 \mathrm{mg}$ de extrato padronizado de M. nigra lote 4A em balança analítica (Shimadzu modelo AY220, São Paulo - SP, Brasil) solubilizados em $5 \mathrm{~mL}$ de $\mathrm{MeOH}$ grau CLAE (2 mg/mL). A solução obtida foi filtrada em unidade de filtração Millex (Merck Millipore, Tullagreen, Carrigtwohill Co. Cork - Irlanda) 0,45 $\mu \mathrm{m}, 13 \mathrm{~mm}$.

Os teores de ácido clorogênico, rutina e isoquercitrina encontrados no extrato padronizado das folhas de $M$. nigra foram quantificados utilizando os valores das áreas dos picos correspondentes ao tempo de retenção na eluição destes marcadores. A concentração de cada marcador na amostra de extrato $(2 \mathrm{mg} / \mathrm{mL})$ foi calculada através da equação da reta obtida pela regressão linear das áreas dos picos versus as concentrações dos padrões. Os teores de cada marcador no extrato padronizado foram calculados pela razão entre a concentração destes na amostra do extrato $(\mu \mathrm{g} / \mathrm{mL})$ e a concentração da amostra $(2 \mathrm{mg} / \mathrm{mL})$, a partir da equação: 
$\operatorname{Teor}(m g / g)=\frac{\text { concentração do analito na amostra } \frac{\mu g}{m L}}{2 \frac{m g}{m L}}$

\subsubsection{Validação da metodologia de determinação dos teores de ácido clorogênico, rutina e isoquercitrina no extrato padronizado de $M$. nigra por CLAE-DAD}

A metodologia analítica descrita foi validada de acordo com as especificações do guia internacional para o setor industrial, Q2B validação de procedimentos analíticos: Metodologia (141) e guia para validação de métodos analíticos e bioanalíticos RE N.ํ 899, de 29 de maio de 2003 da Anvisa (133), conforme exigido pelo Guia de orientação para registro de Medicamento Fitoterápico e registro e notificação de Produto Tradicional Fitoterápico, Instrução Normativa N.ำ 4, de 18 de junho de 2014 (132).

\subsubsection{Seletividade}

A seletividade do método foi verificada pela análise de produtos de degradação da amostra por indução de hidrólise ácida/básica. Desta forma, foram pesados $10 \mathrm{mg}$ de extrato padronizado de $M$. nigra e solubilizados em $1 \mathrm{~mL}$ de $\mathrm{HCl}$ $1 \mathrm{M}$ para hidrólise ácida e $10 \mathrm{mg}$ foram solubilizados em $1 \mathrm{~mL}$ de $\mathrm{NaOH} 1 \mathrm{M}$ para hidrólise básica. Essas soluções foram incubadas a $60^{\circ} \mathrm{C}$ por 60 minutos. Após resfriamento à temperatura ambiente, as soluções foram neutralizadas com $1 \mathrm{~mL}$ de $\mathrm{NaOH} 1 \mathrm{M}$ e $\mathrm{HCl} 1 \mathrm{M}$, respectivamente. Após congelamento, as amostras foram liofilizadas com a finalidade de remover a água interferente na solubilização do extrato, e então foram adicionados $5 \mathrm{~mL}$ de metanol $(2 \mathrm{mg} / \mathrm{mL})$. A análise por CLAEDAD foi realizada em triplicata, comparou-se o tempo de retenção (TR) e as áreas obtidas do pico referente ao ácido clorogênico, rutina e isoquercitrina nas amostras preparadas sem indução de hidrólise ácida/básica, com amostras após indução de hidrólise ácida/básica. 


\subsubsection{Linearidade}

Esta metodologia foi avaliada através do método de regressão linear de 3 (três) curvas de calibração autênticas, pela análise de 9 (nove) concentrações diferentes $(0,1 ; 0,2 ; 0,3 ; 0,4 ; 0,5 ; 1,0 ; 2,5 ; 5,0 ;$ e $10,0 \mu \mathrm{g} / \mathrm{mL})$ dos padrões rutina e isoquercitrina, e 8 (oito) concentrações diferentes $(0,2 ; 0,3 ; 0,4 ; 0,5 ; 1,0 ; 2,5 ; 5,0$; e $10,0 \mu \mathrm{g} / \mathrm{mL}$ ) do padrão ácido clorogênico. O coeficiente de correlação $(r)$, intercepto, inclinação, desvio padrão relativo (DPR) e a soma residual dos quadrados foram determinados pelo software GraphPad Prism 5.0®.

\subsubsection{Precisão}

Na repetibilidade, 6 (seis) replicatas de extrato padronizado de M. nigra, 100 $\%$ da concentração teste $(2 \mathrm{mg} / \mathrm{mL})$, foram analisadas por CLAE-DAD no mesmo dia. A precisão inter-dia foi determinada em triplicata e analisada em três dias diferentes com o mesmo analista. Sendo a repetibilidade e precisão inter-dia expressa como desvio padrão relativo (DPR), determinado pela equação:

$$
D P R=\frac{D P}{C M D} \times 100
$$

Onde $\mathrm{DP}=$ Desvio padrão; $\mathrm{CMD}=$ Concentração média determinada.

\subsubsection{Limite de Detecção (LD)}

O LD foi calculado baseado em parâmetros da curva analítica, em que este pode ser expresso como:

$$
L D=3,3 \times \frac{s}{s}
$$


Onde $s$ é o desvio padrão do intercepto com o eixo do $Y$ de três curvas de calibração construidas na linearidade do método contendo concentrações dos marcadores próximas ao suposto limite de quantificação - de 0,10-0,50 $\mu \mathrm{g} / \mathrm{mL}$ para rutina e isoquercitrina e 0,20-1,0 $\mu \mathrm{g} / \mathrm{mL}$ para ácido clorogênico -, e $S$ é a inclinação da curva de calibração (133).

4.4.1.5. Limite de Quantificação (LQ)

Os mesmos critérios de LD podem ser adotados para o LQ, utilizando a relação 10:1, a partir da equação:

$$
L Q=10 \times \frac{s}{S}
$$

Onde $s$ é o desvio padrão do intercepto com o eixo do $Y$ de três curvas de calibração construidas na linearidade do método contendo concentrações dos marcadores próximas ao suposto limite de quantificação - de 0,10-0,50 $\mu \mathrm{g} / \mathrm{mL}$ para rutina e isoquercitrina e 0,20-1,0 $\mu \mathrm{g} / \mathrm{mL}$ para ácido clorogênico -, e $S$ é a inclinação da curva de calibração (133).

Além do método de cálculo pelos parâmetros da curva, o limite de quantificação também foi avaliado pelo método visual através de 7 determinações nas concentrações 0,10 e $0,075 \mu \mathrm{g} / \mathrm{mL}$ de ácido clorogênico, rutina e isoquercitrina, em que o desvio padrão relativo para cada concentração foi calculado.

\subsubsection{Exatidão}

Para avaliação da exatidão, foram realizadas 9 (nove) determinações contemplando o intervalo linear do procedimento, ou seja, 3 (três) concentrações, baixa, média e alta (80, 100 e $120 \%$, respectivamente), em triplicata. Sendo expressa pela relação entre a concentração média determinada experimentalmente 
e a concentração teórica correspondente:

$$
\text { Exatidão }=\frac{\text { concentração experimental }}{\text { concentração teórica }} \times 100
$$

Expressa também pelo Erro Padrão Relativo (EPR):

$$
E P R=\frac{(\text { concentração média experimental }- \text { valor nominal })}{\text { valor nominal }} \times 100
$$

A exatidão do procedimento analítico em questão foi verificada pelo método de adição de padrão. Desta forma, para obtenção dos valores teóricos, foi calculada a concentração final de cada polifenol na amostra a $100 \%$ (2 mg/mL) e posteriormente $80 \%$ e $120 \%$, sendo alcançadas com $500 \mu \mathrm{L}$ do extrato a $100 \%$ somadas a concentrações variadas dos padrões ácido clorogênico, rutina e isoquercitrina.

Os valores de ácido clorogênico foram obtidos com 10; 20 e $30 \mu \mathrm{L}$ da solução mãe do padrão $(100 \mu \mathrm{g} / \mathrm{mL})$, acrescido metanol até o volume de $2 \mathrm{~mL}$, resultando nas concentrações de 0,$50 ; 1,00$ e 1,50 $\mu \mathrm{g} / \mathrm{mL}$. Alíquotas de $500 \mu \mathrm{L}$ das soluções de padrão foram adicionadas a $500 \mu \mathrm{L}$ da amostra de extrato padronizado $(2 \mathrm{mg} / \mathrm{mL})$, resultando nas concentrações teóricas finais de 0,75; 1,00 e 1,25 $\mu \mathrm{g} / \mathrm{mL}$ (Tabela 2). 
Tabela 2 - Concentração teórica para análise da exatidão de ácido clorogênico de $M$. nigra

\begin{tabular}{cccc}
\hline Concentração (\%) & $\begin{array}{c}\text { Concentração } \\
\text { no extrato } \\
\text { padronizado } \\
(\mu \mathrm{g} / \mathrm{mL})\end{array}$ & $\begin{array}{c}\text { Ácido } \\
\text { Clorogênico } \\
\text { adicionado } \\
(\mu \mathrm{g} / \mathrm{mL})\end{array}$ & $\begin{array}{c}\text { Concentração } \\
\text { final }(\mu \mathrm{g} / \mathrm{mL}) \\
\text { de ácido } \\
\text { clorogênico }\end{array}$ \\
\hline 72 & & 0,25 & 0,75 \\
95 & 0,99 & 0,50 & 1,00 \\
117 & & 0,75 & 1,25 \\
\hline
\end{tabular}

Os valores de rutina foram obtidos com 30; 50 e $70 \mu \mathrm{L}$ da solução mãe do padrão $(100 \mu \mathrm{g} / \mathrm{mL})$, acrescido metanol até o volume de $2 \mathrm{~mL}$, resultando nas concentrações de 1,50; 2,50 e 3,50 $\mu \mathrm{g} / \mathrm{mL}$. Alíquotas de $500 \mu \mathrm{L}$ das soluções de padrão foram adicionadas à $500 \mu \mathrm{L}$ da amostra de extrato padronizado $(2 \mathrm{mg} / \mathrm{mL})$, resultando nas concentrações teóricas finais de 2,02; 2,52 e 3,02 $\mu \mathrm{g} / \mathrm{mL}$ (Tabela 3).

Tabela 3 - Concentração teórica para análise da exatidão de rutina de M. nigra

\begin{tabular}{cccc}
\hline Concentração (\%) & $\begin{array}{c}\text { Concentração } \\
\text { no extrato } \\
\text { padronizado } \\
(\mu \mathrm{g} / \mathrm{mL})\end{array}$ & $\begin{array}{c}\text { Rutina } \\
\text { adicionada } \\
(\mu \mathrm{g} / \mathrm{mL})\end{array}$ & $\begin{array}{c}\text { Concentração } \\
\text { final de rutina } \\
(\mu \mathrm{g} / \mathrm{mL})\end{array}$ \\
\hline 80 & & 0,75 & 2,02 \\
99 & 2,53 & 1,25 & 2,52 \\
119 & & 1,75 & 3,02 \\
\hline
\end{tabular}

Os valores isoquercitrina foram obtidos com 60; 100 e $140 \mu \mathrm{L}$ da solução mãe do padrão $(100 \mu \mathrm{g} / \mathrm{mL})$, acrescido metanol até o volume de $2 \mathrm{~mL}$, resultando nas concentrações de 3,00; 5,00 e 7,00 $\mu \mathrm{g} / \mathrm{mL}$. Alíquotas de $500 \mu \mathrm{L}$ das soluções de padrão foram adicionadas à $500 \mu \mathrm{L}$ da amostra de extrato padronizado $(2 \mathrm{mg} / \mathrm{mL})$, resultando nas concentrações teóricas finais de 3,92; 4,92 e 5,92 $\mu \mathrm{g} / \mathrm{mL}$ (Tabela 4). 
Tabela 4 - Concentração teórica para análise da exatidão de isoquercitrina de $M$. nigra

\begin{tabular}{cccc}
\hline Concentração (\%) & $\begin{array}{c}\text { Concentração } \\
\text { no extrato } \\
\text { padronizado } \\
(\mu \mathrm{g} / \mathrm{mL})\end{array}$ & $\begin{array}{c}\text { Isoquercitrina } \\
\text { adicionada } \\
(\mu \mathrm{g} / \mathrm{mL})\end{array}$ & $\begin{array}{c}\text { Concentração } \\
\text { final de } \\
\text { isoquercitrina } \\
(\mu \mathrm{g} / \mathrm{mL})\end{array}$ \\
\hline 81 & \multirow{4}{*}{4,84} & 1,50 & 3,92 \\
102 & & 2,50 & 4,92 \\
122 & & 3,50 & 5,92 \\
\hline
\end{tabular}

Após adição de padrão às amostras de extrato padronizado (2 $\mathrm{mg} / \mathrm{mL}$ ) previamente filtradas, $10 \mu \mathrm{L}$ foram injetados em cromatógrafo líquido, seguindo as condições analíticas descritas anteriormente.

\subsubsection{Robustez}

A robustez do método cromatográfico foi determinada por análise das amostras sob diferentes condições, mudanças como variação de comprimento de onda (280, 330 e $354 \mathrm{~nm})$, fluxo $(0,3$ e $0,7 \mathrm{~mL} / \mathrm{min})$ e temperatura da coluna (35 e $45^{\circ} \mathrm{C}$ ) foram adotadas. Os efeitos nos parâmetros tempo de retenção e área dos picos foram observados.

4.4.1.8. Quantificação dos lotes de extrato padronizado de M. nigra

Amostras de $2 \mathrm{mg} / \mathrm{mL}$ dos lotes $1 \mathrm{~A}, 2 \mathrm{~A}, 3 \mathrm{~A}, 4 \mathrm{~A}$ e $5 \mathrm{~A}$ do extrato padronizado de $M$. nigra foram avaliadas frente ao método validado para quantificação de ácido clorogênico, rutina e isoquercitrina em cada lote. Todos os experimentos foram realizados em triplicata e seus desvios padrões relativos calculados.

A quantificação dos teores de ácido clorogênico, rutina e isoquercitrina foi 
analisada estatísticamente por ANOVA com método Tukey de comparação múltipla $(p<0,05)$.

As proporções de cada marcador foram calculadas em relação ao composto majoritário através da média da triplicata das concentrações obtidas para cada lote individualmente, segundo a fórmula:

Proporção de cada lote

$$
=\frac{\text { média das concentrações de isoquercitrina }(\mu \mathrm{g} / \mathrm{mL})}{\text { média das concentrações de ácido clorogênico ou rutina }(\mu \mathrm{g} / \mathrm{mL})}
$$

A média das proporções dos cinco lotes foi então calculada.

\section{5. $\quad$ CITOTOXICIDADE DO EXTRATO PADRONIZADO}

\subsubsection{Linhagens celulares avaliadas}

As linhagens celulares aderentes de melanoma de murino (B16F10), queratinócito humano (HaCat) e fibroblasto de camundongo (L-929) foram cultivadas como monocamada em Meio de Eagle Modificado por Dulbecco (DMEM) completo (Sigma) suplementado com $10 \%$ soro fetal bovino e $1 \%$ antibióticos (penicilinaestreptomicina). As células foram mantidas em incubadora à $37^{\circ} \mathrm{C}$ e $5 \% \mathrm{CO}_{2}$ em frascos de cultura celular de $75 \mathrm{~cm}^{2}$ (250 mL, estéreis, apirogênicas, não-citotóxica). A linhagem celular melanoma foi adquirida pelo Banco de Células do Rio de Janeiro - Associação Técnico Científica Paul Ehrlich (Duque de Caxias - RJ, Brasil). As linhagens celulares de queratinócito humano e fibroblasto de camundongo estão descritas e foram adquiridas na American Type Culture Collection (ATCC). Após descongelamento das células, pelo menos 3 passagens foram realizadas para cada linhagem avaliada antes de iniciar os ensaios. 


\subsubsection{Ensaio da citotoxicidade}

O ensaio de citotoxicidade foi avaliado segundo o método MTT descrito por Mosmann (1983) (142), que consiste na conversão do sal de tetrazólio em formazan, utilizando o reagente Cell Counting Kit-8 (CCK-8) (Sigma) que contém WST-8 (sal de tetrazólio solúvel em água).

As células foram removidas do frasco para cultivo de células com tripsina 0,25\%/EDTA $1 \mathrm{mM}$ (Sigma-Aldrich, USA) e semeadas em placas de 96 poços (fundo chato, estéril, não-citotóxica, apirogenica, livre de DNAse e RNAse) à uma densidade de $5 \times 10^{3}$ células por poço para queratinócito e $1 \times 10^{4}$ células por poço para melanoma e fibroblasto, com DMEM $10 \%$ em quantidade suficiente para completar volume final de $200 \mu \mathrm{L}$ por poço. Após 24 horas de incubação a $37^{\circ} \mathrm{C}$ e $5,0 \%$ de $\mathrm{CO}_{2}$, diferentes concentrações de extrato padronizado de $M$. nigra solubilizados em metanol e diluídos em DMEM incolor 5,0\% foram adicionados nos poços, em triplicata. As concentrações de extrato padronizado testadas foram as mesmas do ensaio de inibição enzimática sobre a tirosinase em diluição seriada (1000; $500 ; 250 ; 125 ; 62,5 ; 31,25 ; 15,63 ; 7,81 ; 3,91 ; 1,95 ; 0,98 \mu \mathrm{g} / \mathrm{mL})$ além da concentração de $2 \mathrm{mg} / \mathrm{mL}$. Após 24 horas de incubação das células a $37^{\circ} \mathrm{C}$ e $5,0 \%$ de $\mathrm{CO}_{2}$ o tratamento dos extratos em diferentes concentrações foi removido e então foram acrescentados $190 \mu \mathrm{L}$ de DMEM incolor 5,0 \% e $10 \mu \mathrm{L}$ do reagente WST-8. Após 4 horas de incubação, sob mesmas condições, a leitura da placa foi realizada no leitor automático de microplacas (Beckman Coulter, modelo DTX 800, Lagerhausstrasse - Austria) na absorbância de $450 \mathrm{~nm}$. Para o branco do reagente foram preparados poços contendo $190 \mu \mathrm{L}$ de DMEM incolor $5,0 \%$ com $10 \mu \mathrm{L}$ de WST-8, em triplicata, mantendo o mesmo volume final em todos os poços $(200 \mu \mathrm{L})$, com a finalidade de eliminar variações relacionadas à absorbância da coloração característica do reagente em contato com o meio de cultura após 4 horas de incubação. 


\subsubsection{Avaliação da influência dos solventes na citotoxicidade}

Os solventes utilizados para extrair as folhas de $M$. nigra e solubilizar as amostras do extrato padronizado de $M$. nigra foram avaliados frente à citotoxicidade nas mesmas condições do experimento para a determinação da viabilidade celular, substituindo o volume de amostra pelo solvente testado. O álcool etílico $95 \%$ utilizado no processo extrativo, bem como o metanol utilizado na solubilização do extrato de $M$. nigra para a realização do presente ensaio, foram testados como controle para assegurar que estes solventes, a uma concentração de 5,0\% do volume total no poço (200 $\mu \mathrm{L})$, não são citotóxicos, assegurando a não-interferência nos resultados de viabilidade celular.

\subsubsection{Avaliação da influência dos extratos vegetais frente ao WST-8}

O ensaio de tetrazólio MTT pode levar a resultados falsos positivos ao testar compostos naturais com potencial intrínseco redutor (143), por este motivo, foi preparado um controle pra cada concentração de extrato testado na presença de DMEM e WST-8, sem células, com a finalidade de certificar que o extrato não interfere com o reagente, gerando um resultado falso-positivo.

\subsubsection{Controle de morte celular e viabilidade celular}

A indução de morte celular foi realizada através da adição de SDS 10,0 \% nos poços contendo as linhagens celulares com DMEM incolor 5,0\%, em triplicata. $O$ controle de células vivas foi realizado em poços contendo as linhagens celulares ( $1 \times 10^{4}$ células/poço) e DMEM incolor $5,0 \%$, em cinco replicatas para cada ensaio realizado. 


\subsubsection{Determinação da porcentagem de viabilidade celular}

As porcentagens de viabilidade celular foram calculadas comparando-se a absorbância das amostras (ensaio contendo extrato + WST-8 + células + DMEM) com a do controle das células viáveis (ensaio contendo WST-8 + células + DMEM), em que este foi preparado a partir de $190 \mu \mathrm{L}$ de DMEM incolor 5,0 \% com $10 \mu \mathrm{L}$ de WST-8 sobre as células aderidas, respeitando o mesmo volume final de todos os poços, de $200 \mu \mathrm{L}$, e mantendo as mesmas condições do ensaio. Os valores

correspondentes à absorbância do controle de células viáveis forneceram 0 referencial da viabilidade máxima das ceúlas utilizadas para a realização dos experimentos, ou seja, refere-se à capacidade máxima das células para a formação de formazan a partir do tetrazólio, tendo sido considerada a viabilidade da célula igual a 100 \%. Dessa forma as porcentagens de inibição das amostras foram calculadas de acordo com a seguinte equação:

$$
\text { Viabilidade celular }(\%)=\frac{A \times 100}{C}
$$

Onde C representa a absorbância do controle de células viáveis, subtraída do branco do reagente e A representa a absorbância da amostra subtraída do branco do reagente (DMEM incolor 5,0\%+WST-8).

\subsubsection{Determinação dos valores de $I_{50}$ dos extratos padronizados}

Os valores de $\mathrm{IC}_{50}$ foram determinados através da construção de curvas dose-resposta para o lote 4 do extrato padronizado de $M$. nigra. As soluções vegetais para o ensaio foram preparadas por diluição seriada da solução mãe do extrato vegetal de concentração inicial de $2 \mathrm{mg} / \mathrm{mL}$ até concentração final de 0,98 $\mu \mathrm{g} / \mathrm{mL}(2000 \mu \mathrm{g} / \mathrm{mL} ; 1000 \mu \mathrm{g} / \mathrm{mL} ; 500 \mu \mathrm{g} / \mathrm{mL} ; 250 \mu \mathrm{g} / \mathrm{mL} ; 125 \mu \mathrm{g} / \mathrm{mL} ; 62,5 \mu \mathrm{g} / \mathrm{mL}$; $31,25 \mu \mathrm{g} / \mathrm{mL} ; 15,63 \mu \mathrm{g} / \mathrm{mL} ; 7,81 \mu \mathrm{g} / \mathrm{mL} ; 3,91 \mu \mathrm{g} / \mathrm{mL} ; 1,95 \mu \mathrm{g} / \mathrm{mL} ; 0,98 \mu \mathrm{g} / \mathrm{mL})$. Cada 
diluição foi analisada em triplicata e a porcentagem de viabilidade celular foi calculada.

A curva de viabilidade foi obtida construindo um gráfico com a porcentagem (\%) de viabilidade versus o logaritmo da concentração do extrato vegetal. Os parâmetros de regressão não-linear foram traçados para cada curva e os valores de $\mathrm{IC}_{50}$ foram obtidos utilizando o software GraphPad Prism 5.0®. 


\section{RESULTADOS E DISCUSSÃO}

\subsection{OBTENÇÃO DO EXTRATO PADRONIZADO DAS FOLHAS DE $M$. nigra}

Foram obtidos cinco lotes de extrato padronizado das folhas de M. nigra. A padronização de um método extrativo é fundamental no processo de desenvolvimento de fitoterápicos, que deve apresentar um teor de princípio ativo ou marcador químico necessário para garantir a eficácia e segurança do produto com mínimo de variação (144).

\subsubsection{Reprodutibilidade do processo de obtenção do extrato padronizado de M. nigra}

Foram realizadas cinco extrações diferentes, de acordo com as condições pré-estabelecidas (210 g de folhas/1050 $\mathrm{mL}$ de álcool etílico $95 \%$ ) para avaliar a reprodutibilidade do método de extração. Os parâmetros avaliados foram o teor de sólidos no extrato padronizado anterior à liofilização, o rendimento, o teor de umidade no extrato liofilizado e o perfil cromatográfico por Cromatografia em Camada Delgada.

\subsubsection{Teor de sólidos totais}

Os teores de sólidos totais presentes no extrato etanólico filtrado foram determinados para cada lote, em triplicata, através do medidor por infravermelho (Gehaka modelo IV2000, São Paulo - SP, Brasil), previamente utilizado na medição de umidade das folhas. As médias das triplicatas das medições de sólidos totais e seus desvios-padrões foram calculados e estão representados na Figura 7. 


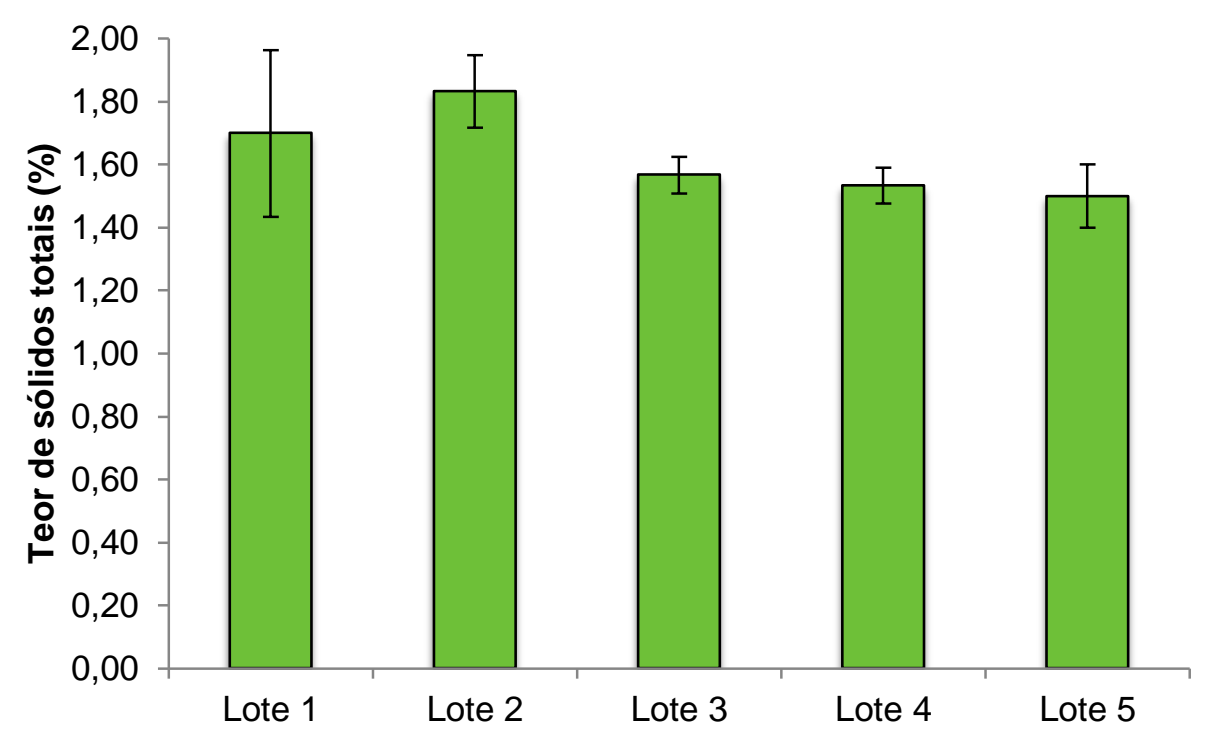

Figura 7 Teor de sólidos totais dos cinco lotes de extrato filtrado de M. nigra.

Os teores de sólidos totais encontrados foram de 1,70\% $\%$ 0,26; $1,83 \% \pm$ 0,$12 ; 1,57 \% \pm 0,06 ; 1,53 \% \pm 0,06$ e $1,50 \% \pm 0,10$ para os lotes $1,2,3,4$ e 5 , respectivamente. A média dos teores de sólidos totais dos cinco lotes de extrato etanólico filtrado de $M$. nigra foi de 1,63\% $\pm 0,14$. Em análise por ANOVA $(p<0,05)$ com método Tukey de comparação múltipla os cinco lotes de extrato $M$. nigra não mostraram diferença significativa entre si para teor de sólidos totais.

\subsubsection{Rendimento}

O lote $3 \mathrm{C}$ foi descartado devido à contaminação fúngica durante o período de secagem em banho Maria, impossibilitando a determinação do peso seco do lote 3 .

O rendimento do extrato padronizado liofilizado para cada lote foi determinado segundo a equação:

$$
\text { Rendimento }(\%)=\frac{\text { peso seco do lote }(g) \times 100}{\text { massa de folhas pulverizadas }(g)}
$$

Onde a massa de folhas pulverizadas para cada lote foi de $210 \mathrm{~g}$. 
Os rendimentos dos processos de extração das folhas de $M$. nigra por etanol $95 \%$ estao listados na Tabela 5. A média do rendimento dos quatro lotes de extrato padronizado de $M$. nigra foi de $7,84 \% \pm 0,49$.

Tabela 5 - Peso seco e rendimento dos lotes do extrato padronizado das folhas de M. nigra

\begin{tabular}{ccc}
\hline $\begin{array}{c}\text { Extrato padronizado das } \\
\text { folhas de } M \text {. nigra }\end{array}$ & Peso seco $(\mathrm{g})$ & Rendimento (\%) \\
\hline Lote 1 & 16,43 & 7,82 \\
Lote 2 & 15,44 & 7,35 \\
Lote 4 & 17,89 & 8,52 \\
Lote 5 & 16,13 & 7,68 \\
\hline
\end{tabular}

Hu et al. (2012) extraíram $5 \mathrm{~kg}$ de folhas de $M$. yunnanensis com $60 \mathrm{~L}$ de etanol $95 \%$, obtendo $500 \mathrm{~g}$ de resíduo (10\% rendimento) (17). Os resultados de rendimento do presente trabalho são similares ao encontrado por Hu et al.

\subsubsection{Teor de umidade}

Os teores de umidade presentes nos extratos liofilizados foram determinados para cada lote, em triplicata, através do medidor por infravermelho (Gehaka modelo IV2000, São Paulo - SP, Brasil), previamente utilizado na medição de umidade das folhas. Conferir o teor de umidade, um indício de qualidade que faz parte do processo de padronização, ajuda a reduzir erros na estimativa da massa real de um material medicamentoso, em que baixa umidade sugere melhor estabilidade contra degradação do produto (130). As médias das triplicatas das medições de teores de umidade e seus desvios-padrões foram calculados e estão representados na Figura 8. 


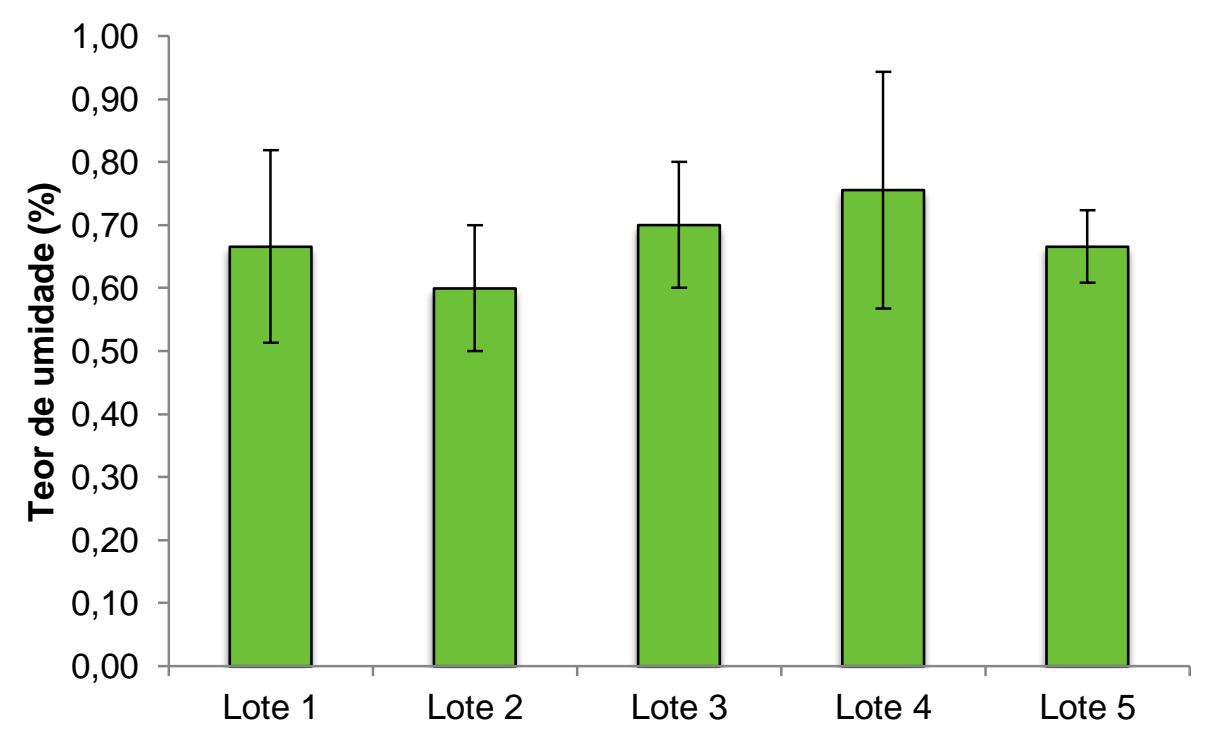

Figura 8 Teor de umidade em cada extração após liofilização.

Os teores de umidade encontrados foram de $0,67 \% \pm 0,15 ; 0,60 \% \pm 0,10$; $0,70 \% \pm 0,10 ; 0,76 \% \pm 0,19$ e $0,67 \% \pm 0,06$ para os lotes $1,2,3,4$ e 5 , respectivamente. A média dos teores de umidade dos cinco lotes de extrato etanólico de $M$. nigra foi de $0,68 \% \pm 0,06$. Em análise por ANOVA $(p<0,05)$, com método Tukey de comparação múltipla, os cinco lotes de extrato de $M$. nigra não mostraram diferença significativa entre si para teor de umidade.

A análise do teor de umidade se faz necessária mesmo para os extratos secos, pois os derivados vegetais são higroscópicos e o excesso de umidade acelera a ação de enzimas, podendo acarretar a degradação de constituintes químicos e desenvolvimento de fungos e bactérias (132).

Os dados sugerem que o perfil do teor de umidade é diretamente proporcional ao rendimento do processo extrativo. Quanto maior o rendimento obtido, maior é o teor de umidade do extrato, conforme observado para o lote 4 , que possui as maiores porcentagens de rendimento $(8,52 \%)$ e umidade $(0,76 \%)$. Em contrapartida, o lote que apresentou menor rendimento $(7,35 \%)$, obteve o menor teor de umidade $(0,60 \%$, lote 2$)$.

Os resultados apresentados demonstraram similaridade entre os cinco lotes de extrato padronizado das folhas de $M$. nigra para os parâmetros avaliados por não serem significativamente diferentes sob análise por ANOVA $(p<0,05)$, com método 
Tukey, indicando que o processo de obtenção do extrato padronizado foi reprodutível nos cinco lotes.

\subsubsection{Cromatografia em Camada Delgada (CCD)}

O perfil cromatográfico é o padrão cromatográfico de constituintes característicos, obtidos em condições definidas, que possibilite a identificação da espécie vegetal em estudo e a diferenciação de outras espécies (131). É utilizado para auxiliar a identificação química do material vegetal, sendo critério de exigência para a droga vegetal, derivado vegetal e produto acabado no momento do registro, notificação ou renovação do registro, além de ser solicitado em algumas petições pós registro. O perfil cromatográfico auxiliará na avaliação da consistência da qualidade e da identidade lote a lote (132).

As colorações amarela e verde escuro das bandas presentes na cromatoplaca foram obtidas durante a eluição em mistura de hexano e acetato de atila (Figura 9A). Após revelação desta cromatoplaca com reagente anisaldeído e subsequente aquecimento, foi observada coloração verde escuro em todas as bandas (Figura 9B). Ao ser visualizada em câmara UV ( $\lambda=365 \mathrm{~nm})$ apresentou coloração vermelha, indicando a presença de clorofila. Os valores do fator de retenção (Rf) foram calculados (Tabela 6). 


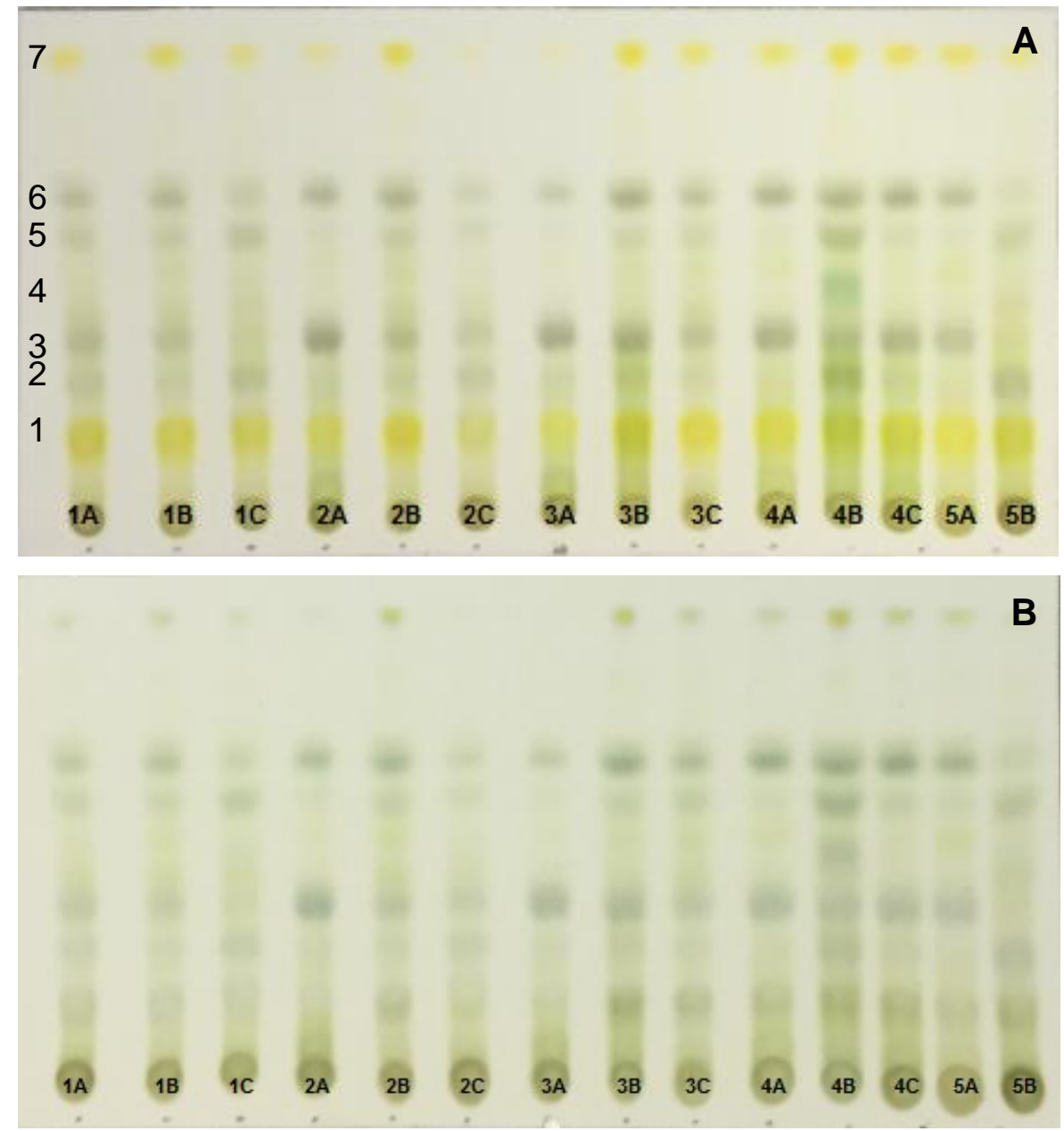

Figura 9 Cromatografia em camada delgada dos extratos padronizados de $M$. nigra (20 mg/mL) (A) eluente: hexano-acetato de etila (7:3); (B) cromatoplaca revelada com anisaldeído e aquecida.

Tabela 6 - Valores do Fator de Retenção (Rf) calculados para o extrato padronizado de $M$. nigra $(20 \mathrm{mg} / \mathrm{mL})$ revelados com anisaldeído

\begin{tabular}{cc}
\hline Banda & $\mathrm{Rf}$ \\
\hline 1 & 0,17 \\
3 & 0,28 \\
4 & 0,38 \\
5 & 0,50 \\
6 & 0,58 \\
7 & 0,68 \\
\hline
\end{tabular}


O reagente de Produtos Naturais (NP) induz a fluorescência em flavonoides. É geralmente utilizado em combinação com uma aplicação subsequente de polietilenoglicol (PEG) para aumentar ainda mais a fluorescência (145). Tem como finalidade a revelação de polifenois, principalmente os flavonoides, que são compostos por 15 átomos de carbono em seu núcleo fundamental, constituído de duas fenilas ligadas por uma cadeia e três carbonos entre elas.

A visualização da cromatoplaca no UV-365 nm borrifada com NP-PEG revela a presença de flavonoides e demais substâncias fenólicas no extrato padronizado de M. nigra devido à coloração amarela fluorescente, como pode ser observado na Figura 10.

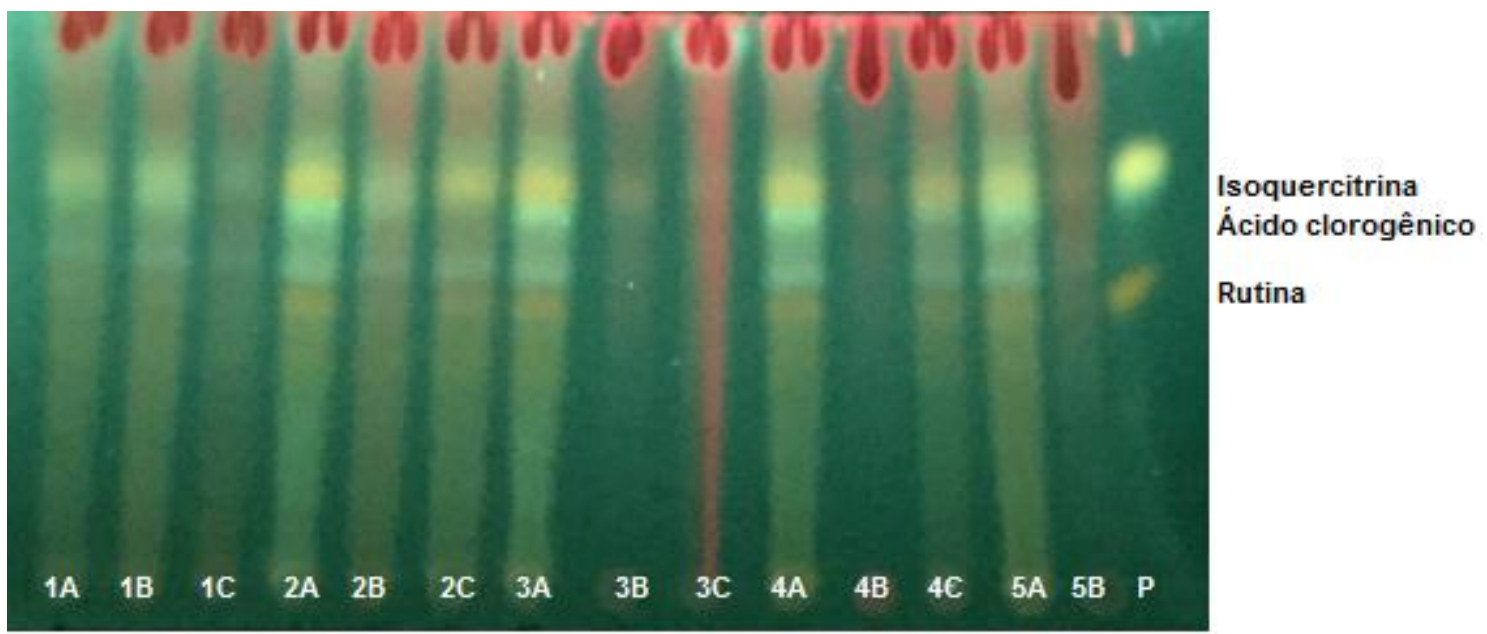

Figura 10 Cromatografia em camada delgada dos extratos padronizados de M. nigra (20 mg/mL) revelados com NP-PEG visualizados em câmara UV $(\lambda=365 \mathrm{~nm})$. P: polifenóis ácido clorogênio, rutina e isoquercitrina $(0,33 \mu \mathrm{g} / \mathrm{mL})$.

A revelação da cromatoplaca com o reagente NP-PEG confirmou a presença dos flavonoides rutina e isoquercitrina - coloração laranja -, e também do polifenol ácido clorogênico - coloração azul esverdeado - segundo Wagner e Bladt (1996) (137) em comparação com estes padrões. As manchas vermelhas que aparecem na frente do solvente são indicativos de clorofila. Os valores de $\mathrm{Rf}$ do extrato padronizado de $M$. nigra foi calculado e comparado aos polifenois ácido clorogênico, rutina e isoquercitrina, demonstrando similaridade entre os valores obtidos (Tabela $7)$. 
Tabela 7 - Valores do Fator de Retenção (Rf) calculados para o extrato padronizado de $M$. nigra $(20 \mathrm{mg} / \mathrm{mL})$ revelados com NP-PEG

\begin{tabular}{ccc}
\hline Banda & Rf extrato $M$. nigra & Rf padrões \\
\hline Rutina & 0,48 & 0,50 \\
Ácido clorogênico & 0,65 & 0,66 \\
Isoquercitrina & 0,69 & 0,71 \\
\hline
\end{tabular}

A cromatografia em camada delgada demonstrou qualitativamente que os extratos padronizados de um mesmo lote armazenados em diferentes recipientes (intra-lote), assim como os extratos padronizados de lotes diferentes (inter-lote) possuem perfis cromatográficos semelhantes, certificando que não houve diferença na composição fitoquímica qualitativa das amostras intra-lotes e inter-lotes.

\subsection{AVALIAÇÃO DA INIBIÇÃO DA ENZIMA TIROSINASE}

\subsubsection{Extratos padronizados de M. nigra}

O método utilizado para avaliar a atividade da enzima tirosinase consiste em um método contínuo, onde é determinada a atividade de difenolase da tirosinase. Nesse método, a oxidação da L-Dopa pela tirosinase produz dopaquinona, que sofre rápida auto-oxidação originando um pigmento de cor laranja, o dopacromo, cuja formação é medida em espectrofotômetro a 475 nm (146).

Para avaliar o potencial de inibição da espécie $M$. nigra sobre a enzima tirosinase, os cinco lotes foram testados e comparados frente ao controle positivo, o padrão ácido kójico, na concentração final de $1000 \mu \mathrm{g} / \mathrm{mL}$. Com a finalidade de estudar o perfil de inibição dos extratos, foram determinados os valores de $\mathrm{IC}_{50}$ destes sobre a atividade da enzima tirosinase através da construção de curvas dose-resposta de diluição seriada dos extratos e do controle positivo ácido kójico com concentrações de $1000 \mu \mathrm{g} / \mathrm{mL}$ a $0,49 \mu \mathrm{g} / \mathrm{mL}$. 
Para a atividade da tirosinase, o inibidor utilizado como controle positivo foi o ácido kójico, um agente natural obtido a partir do fungo Aspergillus oryzae. O ácido kójico é utilizado como agente despigmentante, pois age inibindo a atividade da enzima tirosinase, e consequentemente, inibindo a formação da melanina (147). Devido à intensa coloração do extrato das folhas de M. nigra, foi registrada uma elevada absorbância nos poços da maior concentração estudada, sendo assim, os dados referentes a essa concentração foram desconsiderados e as porcentagens de inibição sobre a enzima tirosinase e os valores de $\mathrm{IC}_{50}$ foram calculados a partir da concentração $250 \mu \mathrm{g} / \mathrm{mL}$, para as amostras e o controle positivo estudados.

As porcentagens de inibição da enzima tirosinase foram de 90,48 \% $\pm 6,02$; $100,00 \% \pm 5,41 ; 93,45 \% \pm 0,35 ; 95,59 \% \pm 5,14$ e $100,00 \% \pm 6,70$ para o lote $1 A$, lote $2 \mathrm{~A}$, lote $3 \mathrm{~A}$, lote $4 \mathrm{~A}$ e lote $5 \mathrm{~A}$, respectivamente. $\mathrm{O}$ controle positivo ácido kójico apresentou atividade inibidora da tirosinase de 99,41\% $\% \pm 0,78$. Os dados demonstraram que os cinco lotes de $M$. nigra foram capazes de inibir a enzima tirosinase, apresentando uma inibição acima de 90 \% até a concentração de 15,625 $\mu \mathrm{g} / \mathrm{mL}$ para todos os lotes, similar ao padrão ácido kójico (Figura 11).

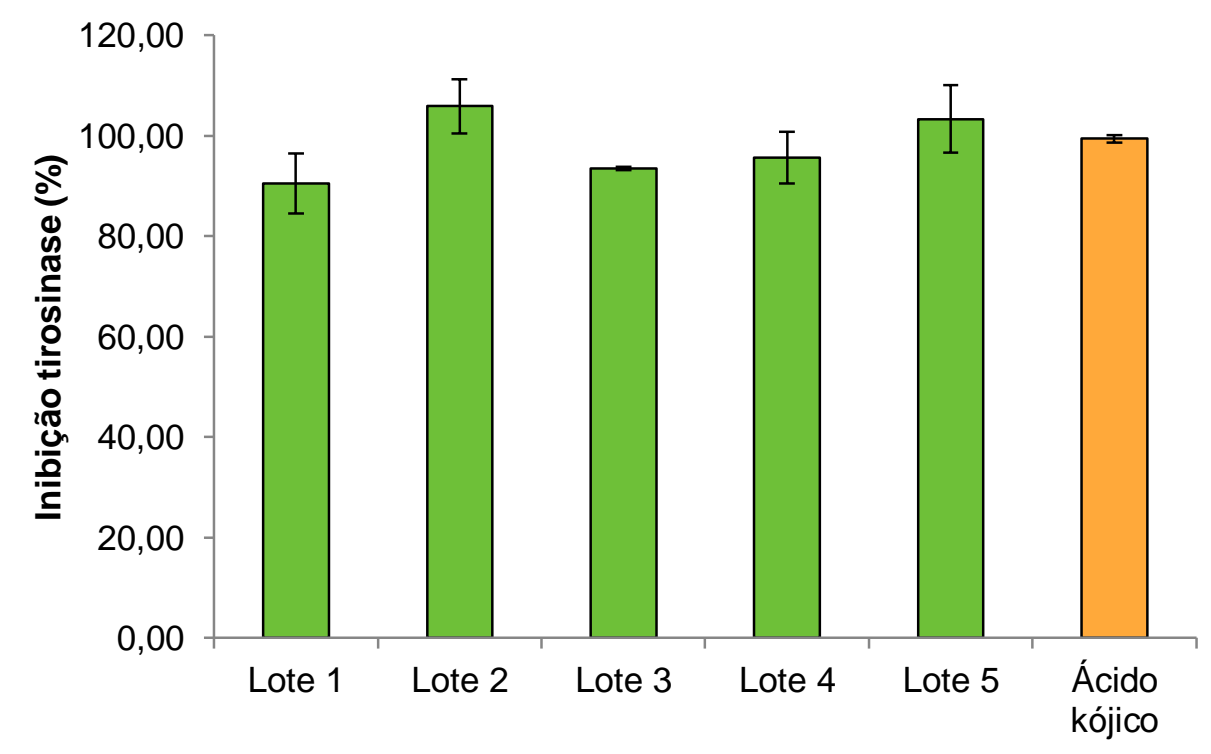

Figura 11 Perfil da atividade de inibição dos cinco extratos padronizados de M. nigra e do controle positivo ácido kójico sobre a tirosinase.

A concentração necessária para inibir $50 \%$ da atividade enzimática $\left(\mathrm{IC}_{50}\right)$ é a medida da eficácia de um composto na função biológica ou bioquímica de inibição. 
Os valores de $\mathrm{IC}_{50}$ calculados foram de $7,75 \mu \mathrm{g} / \mathrm{mL} \pm 1,55 ; 5,14 \mu \mathrm{g} / \mathrm{mL} \pm 0,24 ; 5,00$ $\mu \mathrm{g} / \mathrm{mL} \pm 0,23 ; 7,31 \mu \mathrm{g} / \mathrm{mL} \pm 0,55$ e $8,49 \mu \mathrm{g} / \mathrm{mL} \pm 0,59$ para o lote $1 \mathrm{~A}$, lote $2 \mathrm{~A}$, lote $3 \mathrm{~A}$, lote $4 \mathrm{~A}$ e lote $5 \mathrm{~A}$, respectivamente. O controle positivo ácido kójico obteve $\mathrm{IC}_{50}$ de $3,37 \mu \mathrm{g} / \mathrm{mL} \pm 0,65$. Em análise pelo teste $\mathrm{t}$ de Student os cinco lotes de extrato padronizado de $M$. nigra mostraram diferença significativa $(p<0,05)$ em relação ao ácido kójico (Figura 12).

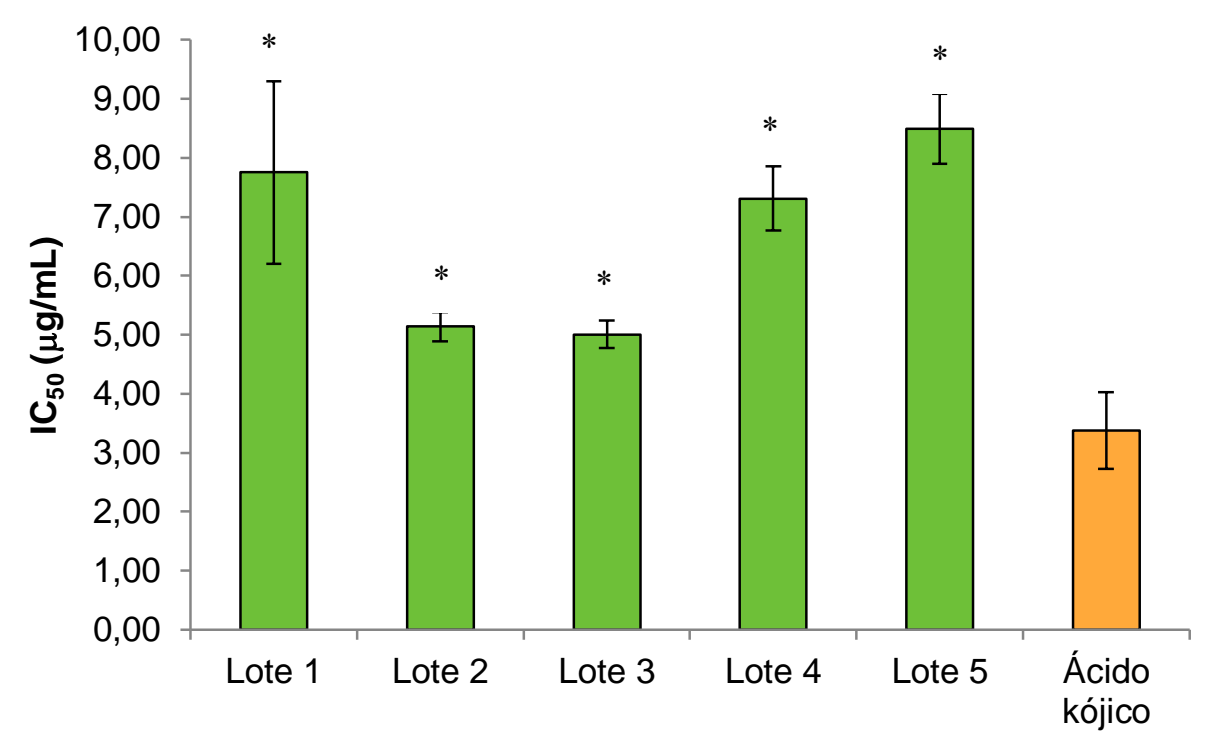

Figura 12 Valores de $\mathrm{IC}_{50}$ dos cinco extratos padronizados de $M$. nigra em relação ao controle positivo ácido kójico sobre a tirosinase com teste t de Student $(p<0,05)$.

A leitura da placa foi realizada 20 minutos após a adição da enzima aos poços contendo as amostras dos extratos etanólicos de cada lote. O dopacromo formado na reação gera absorbância devido à coloração laranja produzida quando a enzima tirosinase degrada o substrato L-tirosina. Não havendo interrupção da reação, o dopacromo formado direciona a síntese de eumelanina (melanina marrom à preta) (32). Desta forma, pode-se sugerir a síntese de eumelanina, uma vez que após 24 horas de reação em temperatura ambiente, foi observado que a coloração laranja referente à formação de dopacromo foi transformada em preta. O controle positivo ácido kójico produziu coloração preta nas concentrações superiores ao valor de $I_{50}$ calculado, enquanto os extratos dos cinco lotes testados produziram coloração preta apenas nas concentrações abaixo do $I_{50}$ calculado, sugerindo que o extrato padronizado de $M$. nigra manteve sua atividade inibitória sobre a tirosinase 
enquanto o padrão ácido kójico não se mostrou estável após 24 horas de reação, observado na Figura 13.

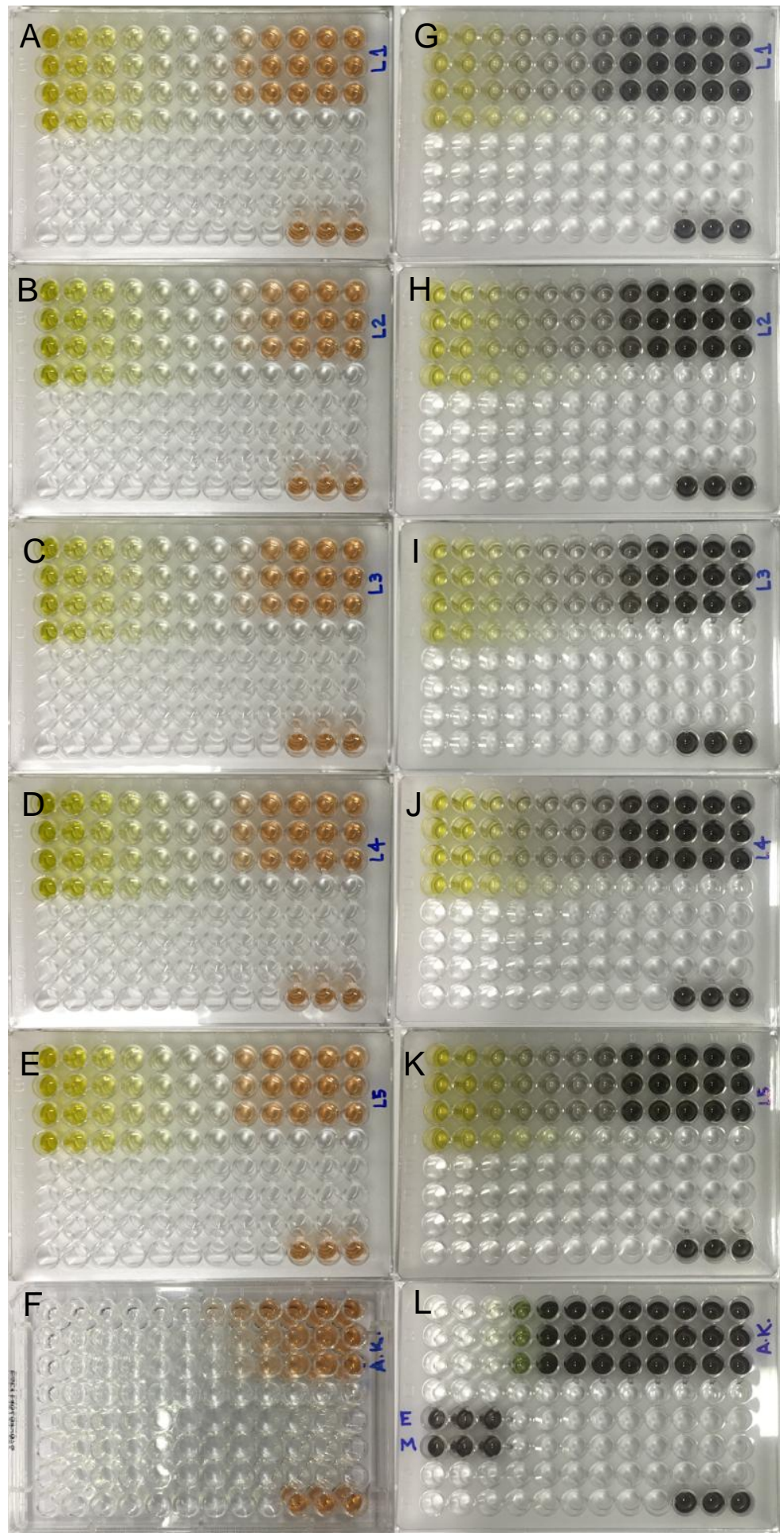

Figura 13 Atividade de inibição da tirosinase pelos cinco extratos padronizados de M. nigra e o controle positivo após 20 minutos de reação $(A)$ lote $1 A$; $(B)$ lote $2 A$; $(C)$ lote $3 A$; $(D)$ lote 4A; $(E)$ lote 5A; $(F)$ ácido kójico. Após 24 horas de reação $(G)$ lote 1A; $(\mathrm{H})$ lote 2A; (I) lote 3A; $(\mathrm{J})$ lote 4A; $(K)$ lote $5 \mathrm{~A} ;(\mathrm{L})$ ácido kójico. 
Os solventes álcool etílico 95 \% utilizado no processo extrativo, bem como o metanol utilizado na solubilização do extrato vegetal para a realização do presente ensaio, a uma concentração de 5,0 \% do volume total no poço (200 $\mu \mathrm{L}$ ), não demonstraram atividade inibidora da tirosinase, assegurando a não-interferência nos resultados de inibição enzimática.

A capacidade de inibição dos cinco lotes de extratos etanólicos das folhas de M. nigra sobre a tirosinase pode ser comparada a do controle ácido kójico, com valores de $\mathrm{IC}_{50}$ entre $5,0 \pm 0,23 \mu \mathrm{g} / \mathrm{mL}$ e $8,49 \pm 0,59 \mu \mathrm{g} / \mathrm{mL}$, para o lote 3 e o lote 5 , respectivamente, comparados frente ao $\mathrm{IC}_{50}$ de $3,37 \pm 0,65 \mu \mathrm{g} / \mathrm{mL}$ do ácido kójico. Pela curva dose-resposta pode ser observado que mesmo na concentração de $15,625 \mu \mathrm{g} / \mathrm{mL}$, os cinco extratos de $M$. nigra continuaram apresentando inibições maiores que $90 \%$.

Resultados semelhantes foram encontrados no estudo de Chang et al. (2011) com o extrato etanólico do galho de $M$. alba L., que mostrou ter atividade contra a tirosinase (atividade de inibição de $78 \%$ para $60 \mu \mathrm{g} / \mathrm{mL}$ ) superior à do extrato etanólico da casca de sua raiz (atividade de inibição de $62 \%$ para $60 \mu \mathrm{g} / \mathrm{mL}$ ), através da capacidade quelante de metal, pela presença dos compostos fenólicos maclurina, rutina, isoquercitrina, resveratrol e morina, sendo esta última superior aos demais, inclusive superior ao extrato etanólico dos galhos (9). Lee et al. (2002) fracionaram 0 extrato metanólico das folhas de $M$. alba obtendo assim mulberrosídeo $\mathrm{F}$, cujo $\mathrm{IC}_{50}$ foi de $0,29 \mu \mathrm{g} / \mathrm{mL}$ sobre a tirosinase, inferior ao obtido pelo controle ácido kójico, de $1,30 \mu \mathrm{g} / \mathrm{mL}$ (8). Wang et al. (2014) avaliaram as atividades monofenolase e difenolase de mulberrosídeo $A$ isolado dos extratos etanólicos (80\%) de M. multicaulis em que os valores de $I_{50}$ obtidos foram de 1,29 $\mu \mathrm{mol} / \mathrm{L}$ e $7,45 \mu \mathrm{mol} / \mathrm{L}$ para as atividades monofenolase e difenolase da tirosinase fúngica, respectivamente (15).

Takahashi et al. (2012), isolaram a 2,4,2',4'-hidroxichalcona a partir do fracionamento do extrato solúvel metanólico da haste de $M$. australis, que inibe a atividade da tirosinase com $\mathrm{IC}_{50}$ de $0,21 \mu \mathrm{M}$, inferior à arbutina $\left(\mathrm{IC}_{50}\right.$ de $\left.164 \mu \mathrm{M}\right)$ (11). Em um estudo conduzido por Zheng et al. (2012), o extrato etanólico (95 \%) da raiz de $M$. australis isolou 22 compostos, dentre eles um novo composto capaz de inibir a tirosinase, austraona $\mathrm{A}\left(\mathrm{IC}_{50} 72,83 \pm 1,66 \mu \mathrm{M}\right)$, além do conhecido inibidor oxiresveratrol $\left(\mathrm{IC}_{50} 2,85 \pm 0,26 \mu \mathrm{M}\right)$, moracenina $\mathrm{D}\left(\mathrm{IC}_{50} 4,61 \pm 0,13 \mu \mathrm{M}\right)$, sanggenon 
$\mathrm{T}\left(\mathrm{IC}_{50} 1,20 \pm 0,04 \mu \mathrm{M}\right)$, kuwanon $\mathrm{O}\left(\mathrm{IC}_{50} 1,81 \pm 0,08 \mu \mathrm{M}\right)$ e mulberrofurano $\mathrm{G}\left(\mathrm{IC}_{50}\right.$ $14,65 \pm 0,32 \mu \mathrm{M})$ que exibiram atividades inibitórias de tirosinase mais potentes que do ácido kójico $\left(\mathrm{IC}_{50} 50,43 \pm 1,75 \mu \mathrm{M}\right)$. Os extratos da raíz $\left(\mathrm{IC}_{50} 22,53 \pm 0,08 \mu \mathrm{g} / \mathrm{mL}\right)$ e galho $\left(\mathrm{IC}_{50} 27,88 \pm 0,11 \mu \mathrm{g} / \mathrm{mL}\right)$ também possuíram atividade inibitória, porém inferiores ao ácido kójico $\left(\mathrm{IC}_{50} 3,26 \pm 0,12 \mu \mathrm{g} / \mathrm{mL}\right)$, exceto o extrato de sua haste $\left(\mathrm{IC}_{50}<2,5 \mu \mathrm{g} / \mathrm{mL}\right)(10)$.

Jeong et al. (2009) isolaram 12 compostos do extrato metanólico (95 \%) das raízes de $M$. Ihou que apresentaram atividade inibitória sobre a tirosinase utilizando L-tirosina como substrato, dentre os quais steppogenina, norartocarpetina e moracina $\mathrm{M}$ obtiveram valores de $\mathrm{IC}_{50}$ de $1,3 \pm 0,3 \mu \mathrm{M}, 1,2 \pm 0,4 \mu \mathrm{M}$ e 7,4 $\pm 1,0 \mu \mathrm{M}$, respectivamente, inferiores ao controle ácido kójico $(16,3 \mu \mathrm{M})(14)$. Em um estudo conduzido por Ryu et al. (2008), os compostos mormina, ciclomorusina, morusina, kuwanon $\mathrm{C}$ e norartocarpetina isolados da casca do caule de $M$. Ihou obtiveram valores de $\mathrm{IC}_{50}$ para atividade monofenolase de 0,088, 0,092, 0,250, 0,135 $\mu \mathrm{M}$ e 1,2 $\mu \mathrm{M}$, respectivamente (13).

Hu et al. (2012) isolaram 10 compostos do caule de M. notabilis, dentre os quais as moracinas $\mathrm{O}$ e $\mathrm{P}$ mostraram efeitos inibitórios na tirosinase fúngica com valores de $\mathrm{IC}_{50}$ inferiores ao do ácido kójico (16). Os valores de $\mathrm{IC}_{50}$ de dois novos compostos isolados do extrato etanólico das folhas de $M$. yunnanensis, morusiunasinas $E(1,43 \pm 0,43 \mu \mathrm{M})$, morusiunasinas $\mathrm{F}(0,15 \pm 0,04 \mu \mathrm{M})$ e duas flavanas conhecidas, (2R)-2',4'-diidroxi-7-metoxi-8-hidroxietilflavana $(0,12 \pm 0,02 \mu \mathrm{M})$ e (2S)-2',4'-diidroxi-7-metoxi-8-prenilflavana $(0,81 \pm 0,17 \mu \mathrm{M})$, demonstraram efeitos inibitórios potentes em tirosinase, superiores ao controle ácido kójico (32,62 \pm 1,24 $\mu \mathrm{M})(17)$.

Em um estudo conduzido por Zheng et al. (2010), foi revelada a presença de nove compostos que mostraram melhores atividades inibidoras da tirosinase que 0 ácido kójico no extrato etanólico $(95 \%)$ da raíz de $M$. nigra. Os valores $\mathrm{IC}_{50}$ de 5'geranil-5,7,2',4'-tetraidroxiflavona $(37,09 \pm 1,74 \mu \mathrm{M})$, steppogenina-7-O- $\beta$-Dglucosídeo $(5,99 \pm 0,03 \mu \mathrm{M}), 2,4,2^{\prime}, 4^{\prime}$-tetraidroxichalcona $(0,062 \pm 0,002 \mu \mathrm{M})$, moracina $\mathrm{N}(30,52 \pm 1,46 \mu \mathrm{M})$, kuwanon $\mathrm{H}(10,34 \pm 0,19 \mu \mathrm{M})$, mulberrofurano $\mathrm{G}(17,53$ \pm 0,26 $\mu \mathrm{M})$, morachalcona A $(0,14 \pm 0,01 \mu \mathrm{M})$, oxiresveratrol-2-O- $\beta$-Dglicopiranosídeo $(29,75 \pm 2,07 \mu \mathrm{M})$, oxiresveratrol-3'-O- $\beta$-D-glicopiranosídeo $(1,64 \pm$ 
$0,10 \mu \mathrm{M})$ foram inferiores ao do controle ácido kójico $(46,95 \pm 1,72 \mu \square)(30)$. Zhang et al. (2009) isolaram a 2,4,2',4'-tetraidroxi-3-(3-metil-2-butenil)-chalcona do extrato etanólico (95\%) da haste de $M$. nigra, a qual obteve potente inibição sobre a tirosinase fúngica com $\mathrm{IC}_{50}$ de 0,95 $\pm 0,04 \mu \mathrm{M}$, comparado ao 24,88 $\pm 1,13 \mu \mathrm{M}$ do ácido kójico (29).

Os achados na literatura confirmam a presença de diversos compostos fitoquímicos inibidores de tirosinase em extratos de diferentes espécies do gênero Morus. Os compostos bioativos isolados demonstraram potente atividade inibitória sobre a enzima de interesse, superior aos controles utilizados, ácido kójico e arbutina. $O$ extrato padronizado das folhas de $M$. nigra se mostrou mais potente que os extratos etanólicos do galho e da casca da raiz de M. alba L. (9) por apresentar atividade inibitória (\%) superior na concentração de $60 \mu \mathrm{g} / \mathrm{mL}$ que estes extratos. $\mathrm{O}$ extrato padronizado das folhas de $M$. nigra também se mostrou mais potente que 0 extrato da raiz e do galho de $M$. australis (10), por apresentar valores de $\mathrm{IC}_{50}$ quase 3 vezes inferiores.

A folha de $M$. nigra ainda não foi investigada e pode servir como um agente cosmético adequado para clareamento da pele, já que as demais espécies do gênero Morus possuem, em distintas porções de sua planta, diversos compostos que inibem a enzima tirosinase.

\subsection{AVALIAÇÃO DO PERFIL CROMATOGRÁFICO POR CROMATOGRAFIA LÍQUIDA DE ALTA EFICIÊNCIA (CLAE) E DETERMINAÇÃO DOS TEORES DE ÁCIDO CLOROGÊNICO, RUTINA E ISOQUERCITRINA}

Após obtenção de cinco lotes do extrato padronizado de $M$. nigra, semelhantes em rendimento, teor de umidate, teor de sólidos totais e perfil em CCD, foi realizada a avaliação do perfil cromatográfico em CLAE-DAD do lote 4A, visando a identificação e quantificação dos compostos majoritários presentes no extrato.

O método analítico utilizado no presente trabalho foi descrito por Leite et al. (2014) (140), no qual uma amostra do extrato $(5 \mathrm{mg} / \mathrm{mL})$ foi analisada sob diferentes 
fluxos (0,3-0,8 $\mathrm{mL} / \mathrm{min})$ com a finalidade de avaliar qual seria o fluxo mais adequado para separação dos compostos presentes no extrato padronizado de M. nigra, conforme demonstrado na Figura 14. No fluxo de $0,3 \mathrm{~mL} / \mathrm{min}$ o pico de ácido clorogênico não está totalmente definido. Nos fluxos de 0,5, 0,6 e 0,7 mL/min este analito possui maior definição do pico, apresentando melhor separação dos demais compostos presentes no extrato e consequentemente facilitando sua integração. Em 0,8 mL/min é possível observar a coeluição de ácido clorogênico com outro pico próximo a ele. Os flavonoides rutina e isoquercitrina possuem boa separação dos demais compostos presentes no extrato nos fluxos $0,3,0,4$ e $0,5 \mathrm{~mL} / \mathrm{min}$, porém em 0,6 $\mathrm{mL} / \mathrm{min}$ é possível observar coeluição da rutina com um pico próximo a ela. Desta forma, o método utilizado na análise por CLAE-DAD foi modificado com determinação do fluxo de $0,5 \mathrm{~mL} / \mathrm{min}$, pois foi observada melhor separação dos compostos de interesse. 

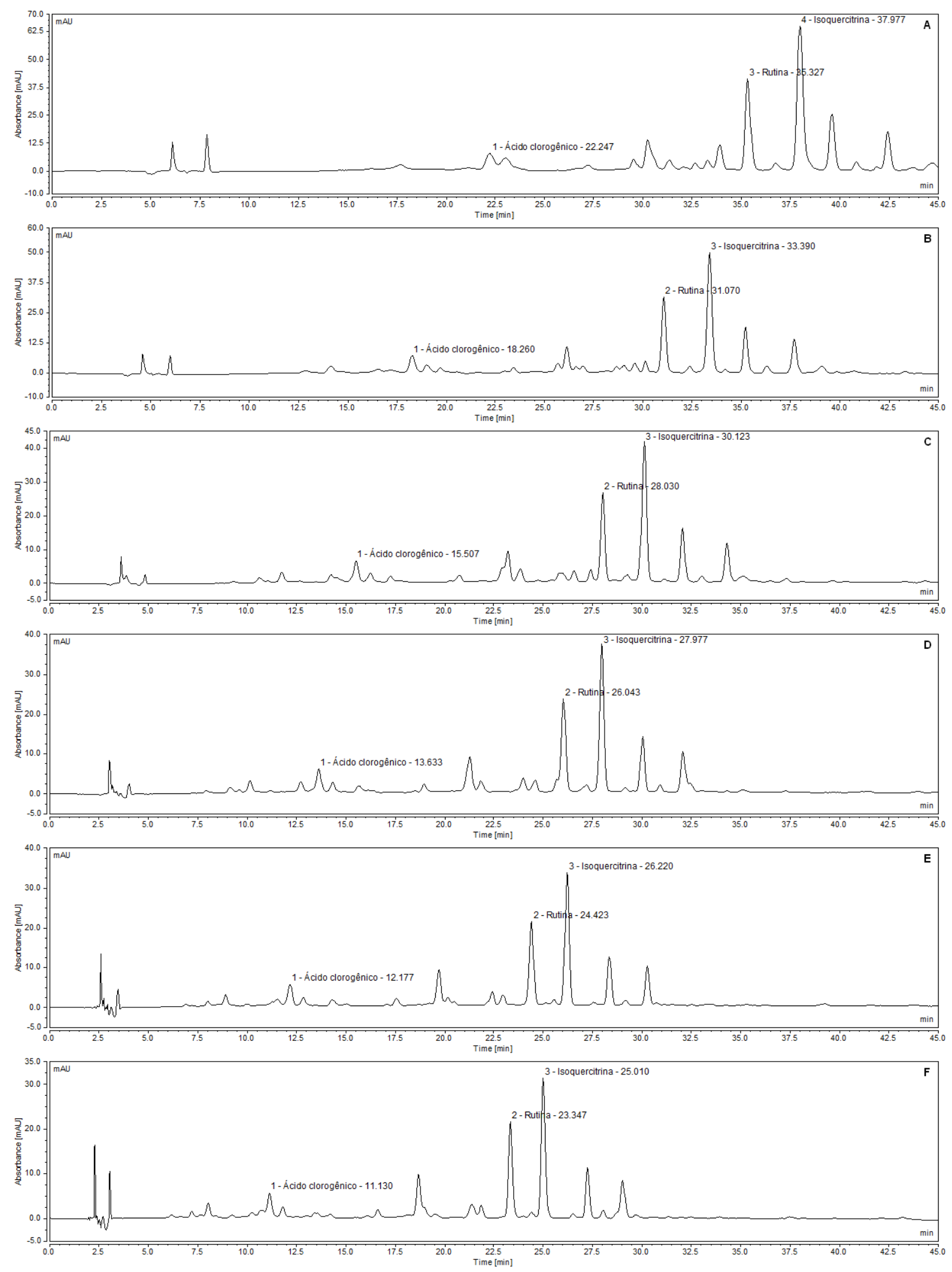

Figura 14 Cromatograma obtido por CLAE do extrato padronizado de M. nigra 5 $\mathrm{mg} / \mathrm{mL}$. Condições de análise: coluna PurospherStar RP C18 mantida a 25ํㅜ; eluente: bomba A (acido fosfórico $1 \%$ ), bomba C (acetonitrila); detector: DAD; sistema de eluição: gradiente; fluxo (A) 0,3 mL/min; (B) 0,4 mL/min; (C) $0,5 \mathrm{~mL} / \mathrm{min}$; (D) $0,6 \mathrm{~mL} / \mathrm{min}$; (E) $0,7 \mathrm{~mL} / \mathrm{min}$; (F) $0,8 \mathrm{~mL} / \mathrm{min}$. 
Após determinação do fluxo, o método foi avaliado frente a diferentes concentrações do extrato padronizado de $M$. nigra ( $1 \mathrm{mg} / \mathrm{mL}, 2 \mathrm{mg} / \mathrm{mL}$ e $4 \mathrm{mg} / \mathrm{mL}$ ), conforme demonstrado na Figura 15. Foi possível observar coeluição do pico de ácido clorogênico com um pico próximo a ele na amostra mais concentrada (4 $\mathrm{mg} / \mathrm{mL})$.

Através do estabelecimento da faixa de concentração dos marcadores de interesse para trabalho - 0,10-10,0 $\mu \mathrm{g} / \mathrm{mL}$ para rutina e isoquercitrina e $0,20-10,0$ $\mu \mathrm{g} / \mathrm{mL}$ para ácido clorogênico - foi construida uma curva de calibração, na qual foi obtida a equação da reta. A partir desta foi possível quantificar os teores de ácido clorogênico, rutina e isoquercitrina no extrato padronizado de $M$. nigra. A concentração de extrato que obteve os teores destes marcadores dentro da faixa de concentração pré-estabelecida foi a de $2 \mathrm{mg} / \mathrm{mL}$, sendo esta a concentração de extrato padronizado de $M$. nigra escolhida para realização dos ensaios.

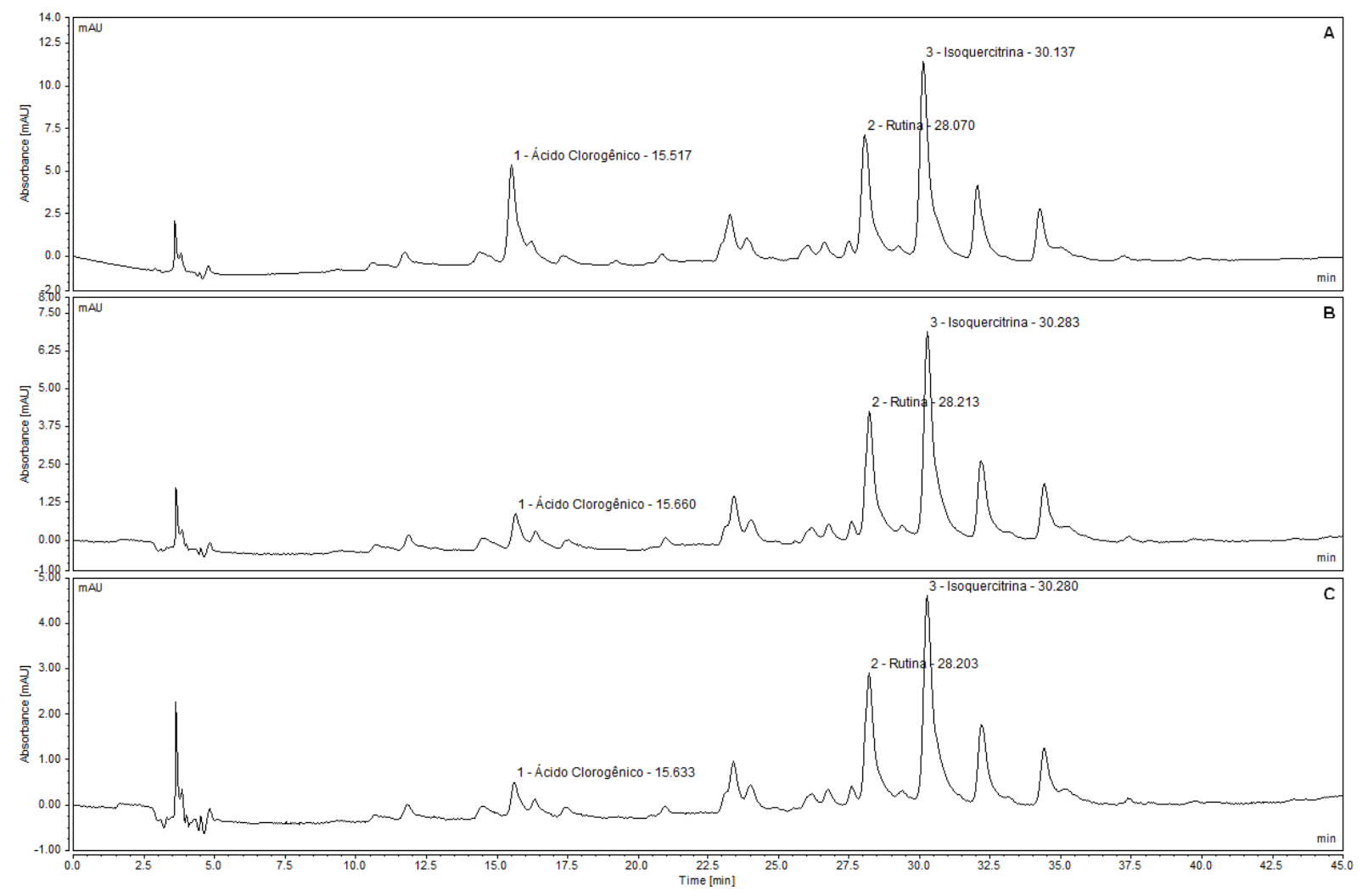

Figura 15 Cromatograma obtido por CLAE. Condições de análise: coluna PurospherStar RP C18 mantida a 25ํㅜ; eluente: bomba A (acido fosfórico $1 \%$ ), bomba C (acetonitrila); detector: DAD; sistema de eluição: gradiente; concentração do extrato padronizado de M. nigra (A) $4 \mathrm{mg} / \mathrm{mL}$; (B) $2 \mathrm{mg} / \mathrm{mL}$; (C) $1 \mathrm{mg} / \mathrm{mL}$. 
O perfil cromatográfico por CLAE-DAD do extrato padronizado das folhas de M. nigra apresentou quinze picos principais de substâncias presentes no extrato (Figura 16). Dentre estas, foram identificadas ácido clorogênico, rutina e isoquercitrina por comparação do tempo de retenção e espectro UV com os padrões (Figura 17, Figura 18 e Figura 19).

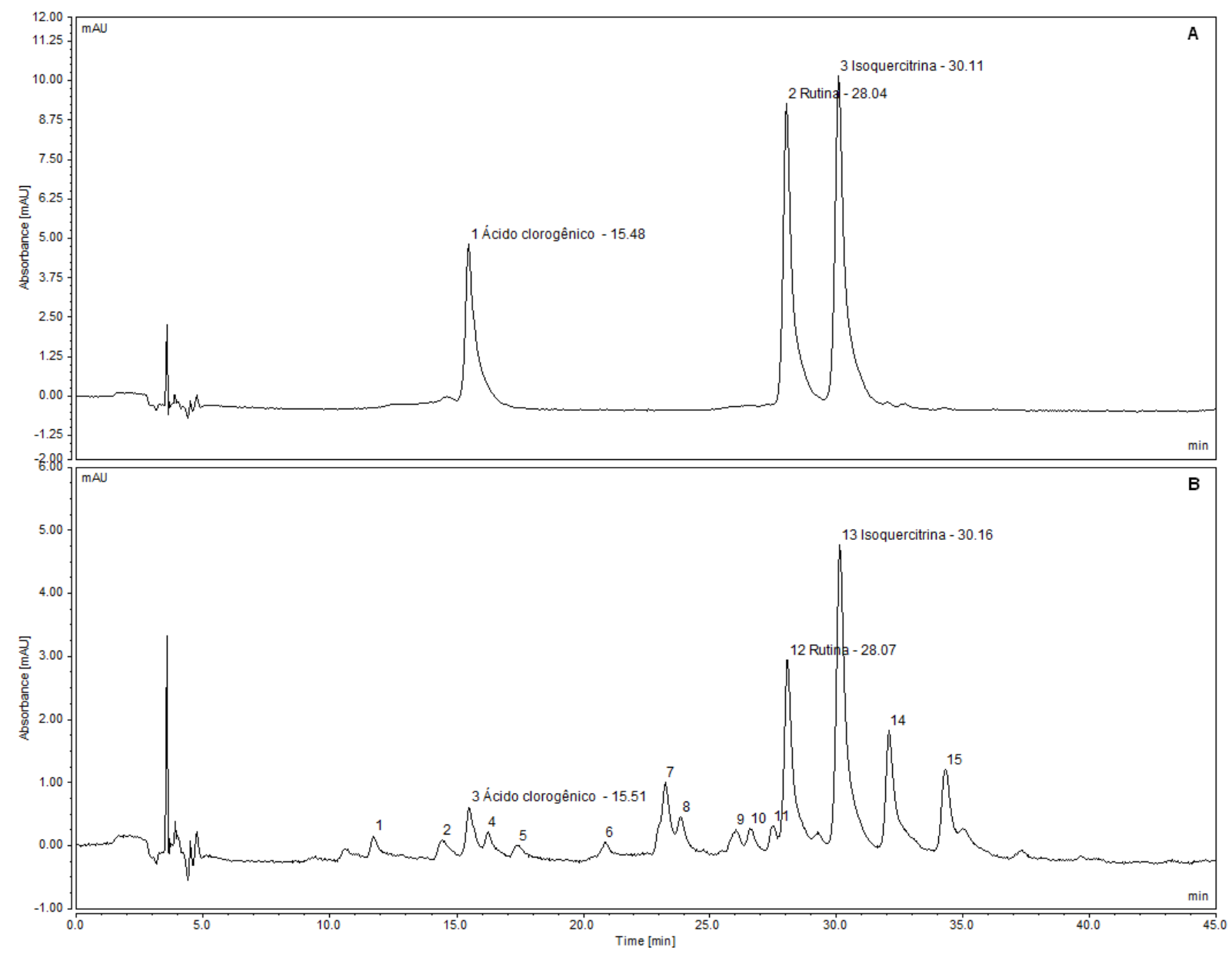

Figura 16 Cromatograma obtido por CLAE. Condições de análise: coluna: PurospherStar RP C18 mantida a 25우 fluxo: 0,5 mL/min; eluente: bomba A (acido fosfórico $1 \%$ ), bomba $C$ (acetonitrila); detector: $\mathrm{DAD}$; sistema de eluição: gradiente. (A) padrões ácido clorogênico, rutina e isoquercitrina $10 \mu \mathrm{g} / \mathrm{mL}$ (B) extrato padronizado de $M$. nigra $\lambda=354 \mathrm{~nm}$. 

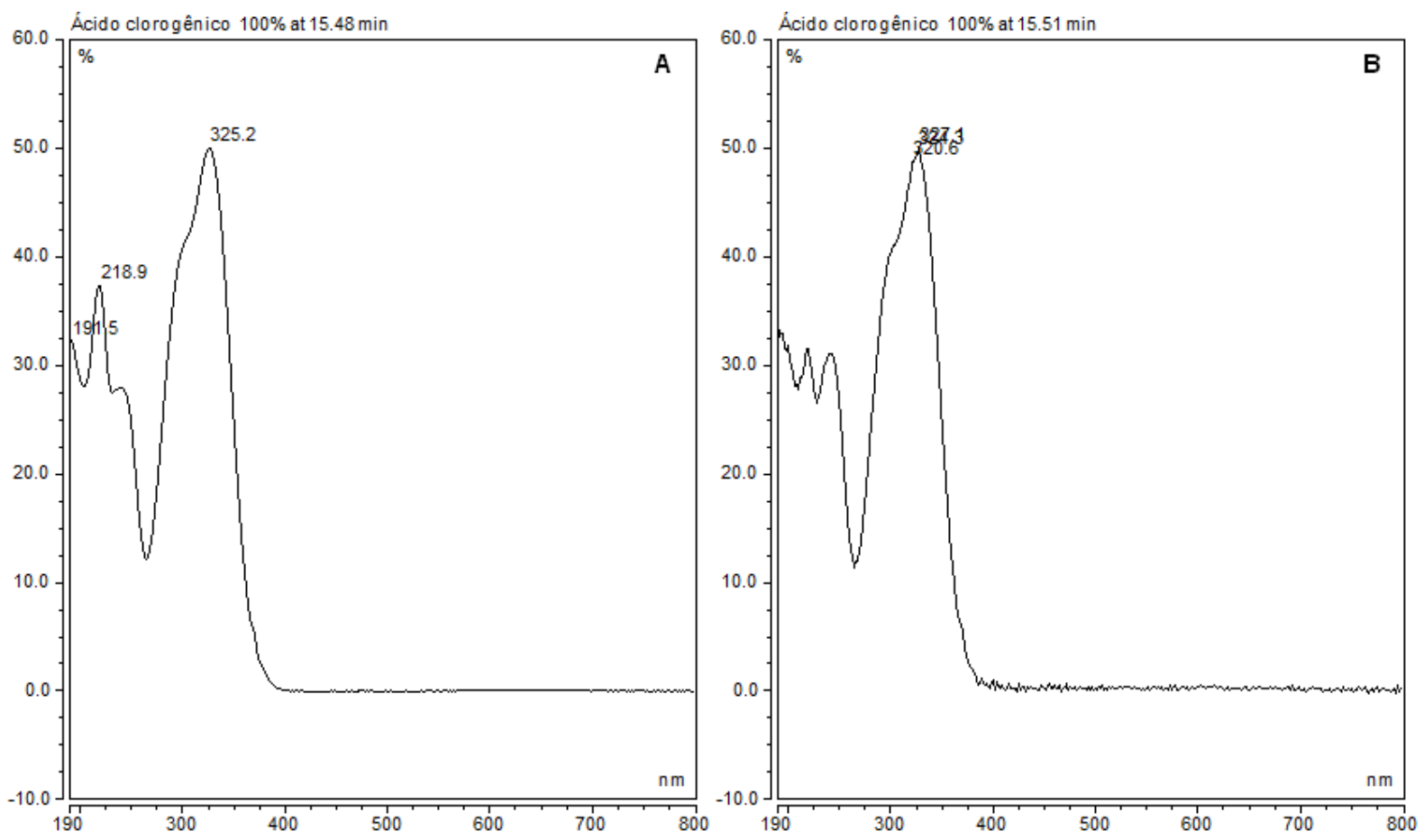

Figura 17 Espectro UV do ácido clorogênico (A) padrão; (B) extrato padronizado de M. nigra.
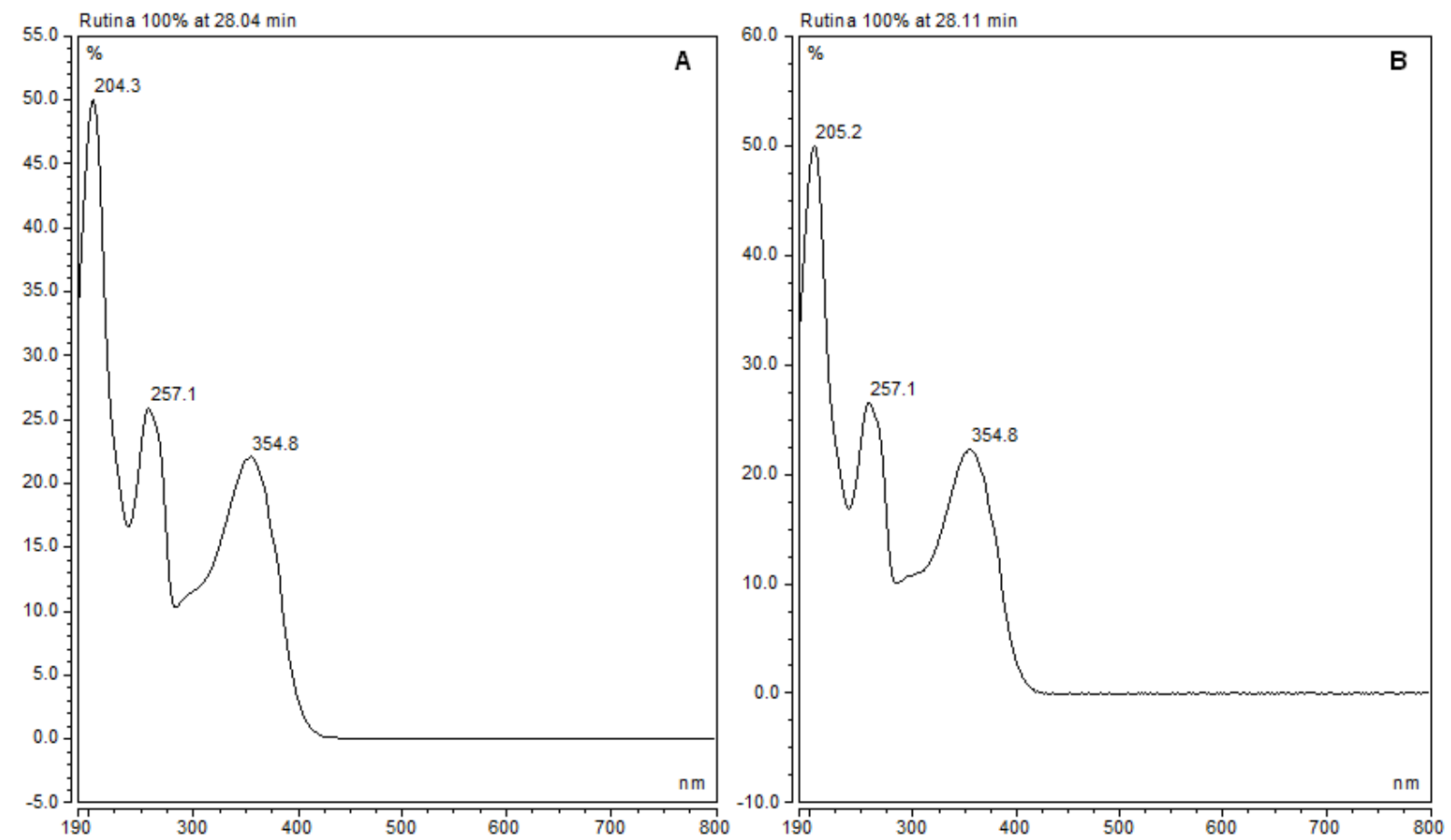

Figura 18 Espectro UV da rutina (A) padrão; (B) extrato padronizado de $M$. nigra. 

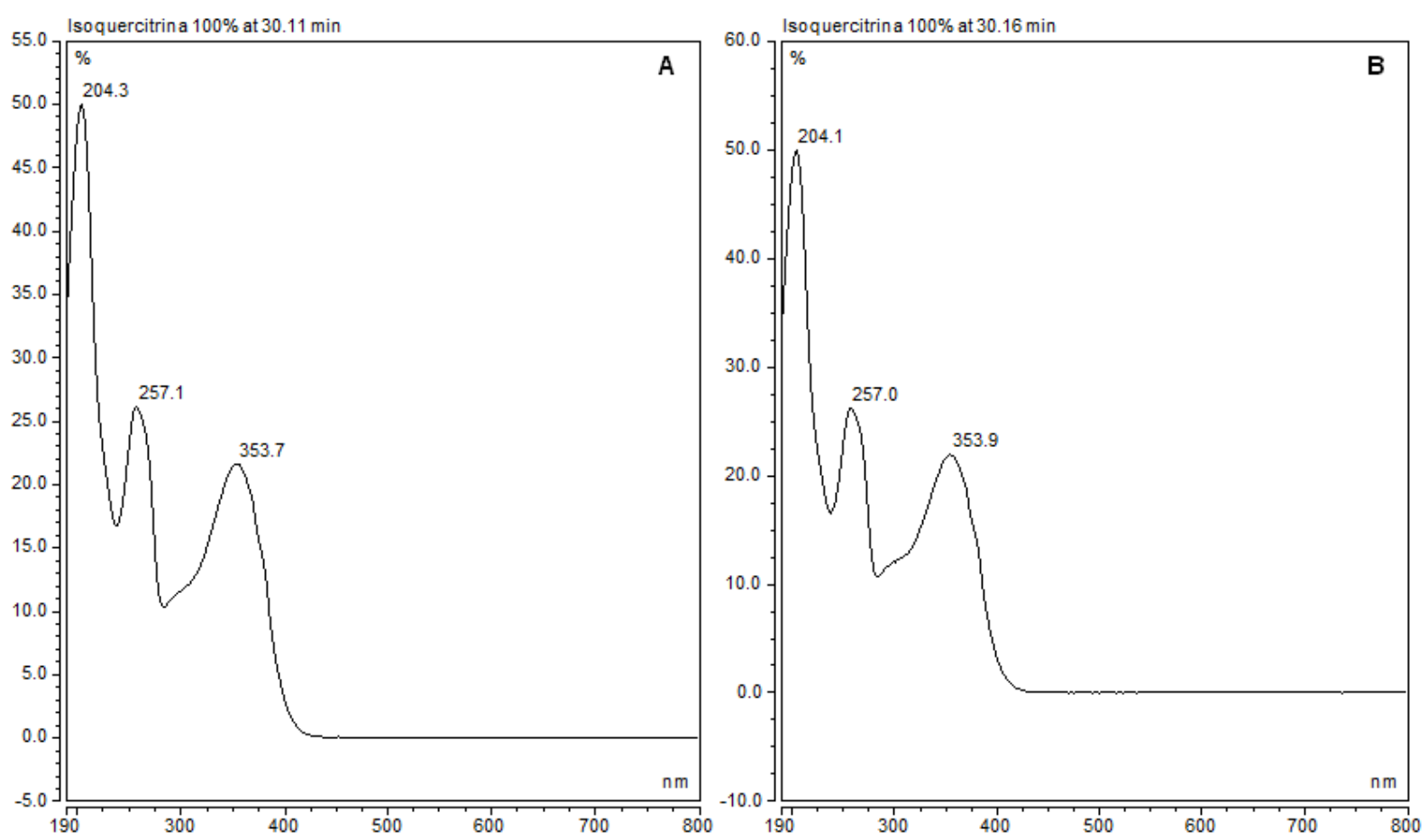

Figura 19 Espectro UV da isoquercitrina (A) padrão; (B) extrato padronizado de $M$. nigra.

Ácido clorogênico (Figura 20A), ou ácido 5-O-cafeoilquínico deduzido por Fischer e Dangschat em 1932, é o mais importante derivado do ácido cinâmico e acumula em níveis elevados em algumas plantas de cultivo, como o café, maçãs e peras. É um composto bioativo importante, abundante em alguns medicamentos tradicionais chineses, como flores e botões de Lonicera japonica e folhas da Eucommia ulmoides. Suas atividades biológicas incluem efeitos anti-inflamatórios; é inibidor de a-glicosidase, sendo um candidato promissor para o desenvolvimento de medicamentos contra diabetes tipo II e contra AIDS; e possui atividade antioxidante devido à inibição da formação de espécies reativas de oxigênio (ROS) (148). Um estudo conduzido por Kang et al. (2013) mostrou que ácido clorogênico é capaz de mudar a expressão gênica e regular os genes responsivos envolvidos nas vias imunes, além da expressão de fatores do sistema imunológico serem melhoradas para promover a ativação e proliferação de células $T$, macrófagos e células NK, suprimindo a taxa de crescimento de células tumorais (149). Segundo Xu et al. (2010) e Yun et al. (2011), ácido clorogênico possui efeitos hepatoprotetores sendo um potencial agente para uso no tratamento clínico de isquemia e reperfusão hepática $(150,151)$. Ji et al. (2013) demonstraram que ácido clorogênico combate 
dano hepático induzido por paracetamol prevenindo apoptose e dano de estresse oxidativo (152). Em um estudo conduzido por Shi et al. (2013), o ácido clorogênico mostra efeito antiinflamatório, pois inibe eficientemente as respostas inflamatórias induzidas por lipopolissacarideo em células hepáticas (153). De acordo com Shi et al. (2009), ácido clorogênico inibe a fibrose hepática induzida em ratos, podendo ser um medicamento eficaz para a prevenção de fibrose hepática (154).

Assim como o ácido clorogênico, a rutina (Figura 20B) também desempenha um papel importante na atividade anti-diabética, identificada no extrato etanólico (70 \%) das folhas de M. alba (155). Em um estudo conduzido por Kamalakkannan e Prince (2006), a administração oral de rutina em ratos diabéticos induzidos por streptozotocina diminuiu significativamente a glicose plasmática de jejum, hemoglobina glicada, aumentou os níveis de insulina, peptídeo $\mathrm{C}$, hemoglobina e proteína (156). Rutina reparou a vasodilatação comprometida causada pela redução da disponibilidade de óxido nítrico na diabetes, segundo Fuentes et al. (2013) (157). Os efeitos neuroprotetores (158-160), atividade antiapoptótica $(158,161)$ e atenuação da inflamação renal induzida por cisplatina (161) foram comprovadas pela rutina. Em um estudo conduzido por Rodrigues et al. (2003), foi possível demonstrar os efeitos benéficos da rutina, com elevação do colesterol-HDL e diminuição dos fatores de risco para a aterosclerose e doenças cardiovasculares, que estão associados à elevação na atividade da enzima antioxidante superóxido dismutase (162). A administração de rutina, entre outros polifenóis, reduziu os ácidos biliares secundários, os quais são fatores de risco para o câncer do cólon, segundo Han et al. (2009) (163).

A isoquercitrina (Figura 20C), quercetina-3-O-glicosideo ou quercetina-3-O- $\beta$ d-glicopiranosideo pode ser obtida pela hidrólise enzimática da rutina e possui diversos efeitos quimioprotetores in vitro e in vivo, contra o estresse oxidativo, câncer, disfunções cardiovasculares, diabetes e reações alérgicas (164). É um potente antioxidante, sequestrador de ROS, e a mais eficaz entre 7 compostos isolados de Thuja orientalis em atenuar a morte de células causada pela exposição ao peróxido de hidrogênio, em um estudo conduzido por Jung et al. (2010) (165). Amado et al. (2009) isolaram isoquercitrina das partes aéreas de Hyptis fasciculata, a qual reduziu a proliferação celular de glioblastoma, um tumor cerebral, sem induzir apoptose (166). Rutina e isoquercitrina aumentaram significativamente enzimas antioxidantes catalase, superóxido dismutase, glutationa peroxidase e níveis de 
glutationa que foram atenuados por oxidopamina em células de feocromocitoma, mostrando-se eficazes na supressão da peroxidação lipídica, prevenindo dano celular, segundo Magalingam et al. (2015) (167). Segundo Rogerio et al. (2007) isoquercitrina é uma eficaz supressora de inflamação iosinofílica, sugerindo um potencial para o tratamento de alergias (168).
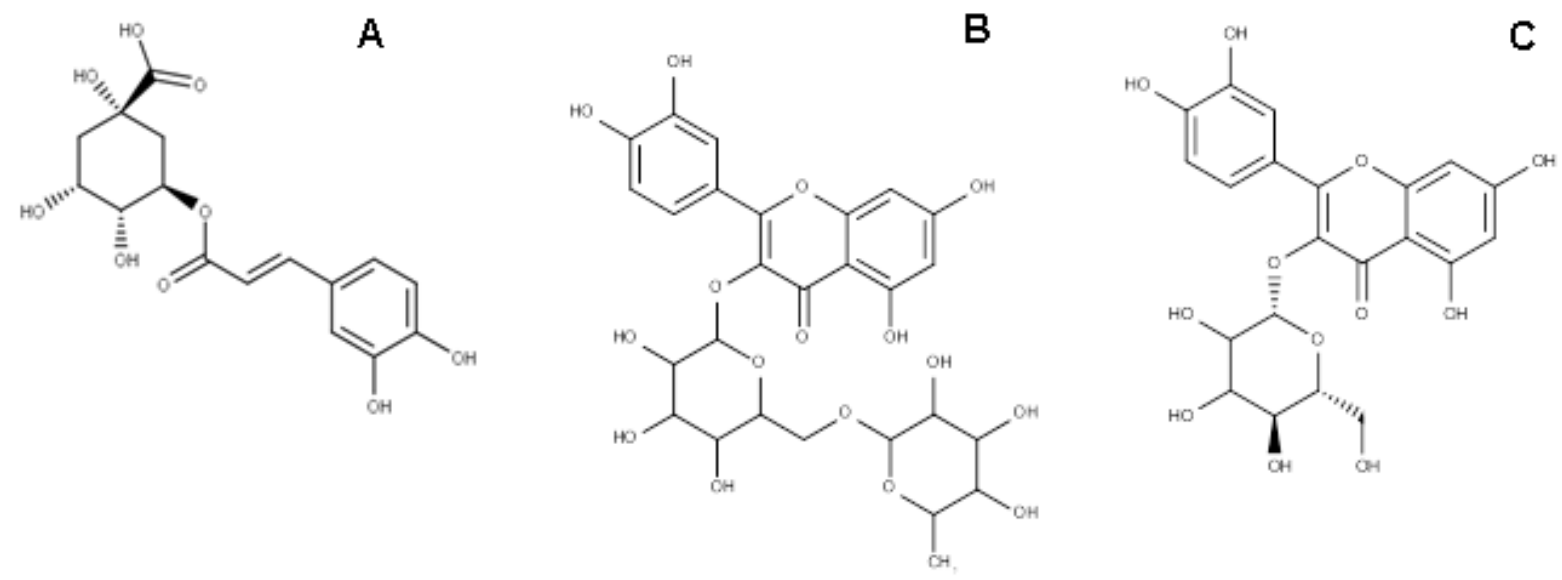

Figura 20 Estruturas moleculares dos compostos identificados no extrato padronizado das folhas de M. nigra. (A) Ácido 5-O-cafeoilquínico (ácido clorogênico); (B) Quercetina-3-O-rutinosideo (rutina); (C) Quercetina-3-O-glicosideo (isoquercitrina).

Si et. al. (2012) investigaram a inibição de tirosinase pela rutina utilizando uma simulação computacional, onde concluíram que a ligação de rutina à tirosinase provoca um tipo de inibição competitiva. A inibição da tirosinase pela rutina envolve exposições da superfície hidrofóbica em certas concentrações de rutina. Os processos cinéticos monofásico e bifásico ocorreram durante a inativação da tirosinase mediada pela rutina. Um cobre que coordenava com resíduos de histidina no sítio ativo da tirosinase foi diretamente quelado pela rutina no estado de equilíbrio (169). Chang et al. (2011) sugeriram que agentes quelantes de metal poderiam ser utilizados como inibidores de tirosinase, assim, a capacidade quelante de metais do extrato etanólico dos galhos de $M$. alba e os seus compostos de referência foram determinados, demonstrando que rutina e isoquercitrina possuem efeito quelante sobre metais de $23,4 \%$ e $27,6 \%$, respectivamente, indicando que possuem atividade de ligação a metais e consequentemente efeitos inibitórios da tirosinase (9). Ziaullah et al. (2013) sintetizaram duas séries de ésteres de ácidos graxos de 
cadeia longa de floridzina e isoquercitrina, e demonstrou que esta possui maior atividade inibidora de tirosinase. De acordo com a relação estrutura-atividade dos seus precursores, o potencial de inibição diminui com a adição de dupla ligações e/ou comprimento da cadeia. A partir do perfil de atividade, pode concluir-se que a presença de ligações duplas é crucial para a inibição, mas o aumento no comprimento da cadeia, depois de um certo limite, proíbe a molécula de entrar no núcleo da enzima (170). Na busca por produtos naturais inibidores de melanogênese, Ohguchi et al. (2010) isolaram isoquercitrina e hiperina a partir do fracionamento do extrato acetônico da casca de Diospyros kaki "Fuyu", em que a isoquercitrina inibiu o teor de melanina com $\mathrm{IC}_{50}$ de $21,7 \mu \mathrm{M}$, significativamente superior ao ácido kójico. Isoquercitrina demonstrou baixa atividade inibitória sobre a tirosinase in vitro, porém os níveis da expressão de tirosinase por análise de Western blot foram diminuídos, o que sugere que a isoquercitrina suprimiu a melanogênese reduzindo a expressão da tirosinase, inibindo sua atividade enzimática (171). Desta forma, é possível concluir que dois dos compostos majoritários do extrato padronizado das folhas de $M$. nigra - rutina e isoquercitrina são flavonoides conhecidos pela atividade inibitória da tirosinase, contribuindo para a atividade biológica desta espécie no tratamento da hiperpigmentação.

Foram utilizados os valores das áreas dos picos correspondentes ao tempo de retenção na eluição do ácido clorogênico, rutina e isoquercitrina para a quantificação destes compostos no extrato padronizado de M. nigra. Para o cálculo foi empregada uma equação da reta obtida pela regressão linear das áreas dos picos versus as concentrações dos padrões ácido clorogênico, rutina e isoquercitrina, demonstrados na Tabela 8.

Tabela 8 - Concentração de ácido clorogênico, rutina e isoquercitrina em $2 \mathrm{mg} / \mathrm{mL}$ do extrato padronizado de $M$. nigra

\begin{tabular}{cccc}
\hline Marcador & Equação da reta & $\begin{array}{c}\text { Áreas obtidas } \\
\left(\mathrm{mAU}^{*} \mathrm{~min}\right)\end{array}$ & $\begin{array}{c}\text { Concentração } \\
(\mu \mathrm{g} / \mathrm{mL})\end{array}$ \\
\hline Ácido clorogênico & $y=0,2115 x-0,0481$ & $0,16 \pm 0,02$ & $0,99 \pm 0,07$ \\
Rutina & $y=0,3678 x-0,0343$ & $0,90 \pm 0,01$ & $2,53 \pm 0,02$ \\
Isoquercitrina & $y=0,421 x-0,048$ & $1,99 \pm 0,02$ & $4,84 \pm 0,04$
\end{tabular}

*Os resultados a média \pm desvio padrão de três experimentos. 
Os teores de ácido clorogênico, rutina e isoquercitrina encontrados no extrato padronizado das folhas de $M$. nigra foram calculados pela razão entre a concentração destes na amostra do extrato $(\mu \mathrm{g} / \mathrm{mL})$ e a concentração da amostra (2 $\mathrm{mg} / \mathrm{mL}$ ), resultando em $0,50 \mathrm{mg} / \mathrm{g} ; 1,265 \mathrm{mg} / \mathrm{g}$ e 2,42 mg/g, respectivamente, sendo este último identificado como composto majoritário deste extrato vegetal.

Silva (2012) também encontrou ácido clorogênico no extrato hidroalcóolico nas folhas de M. nigra (172), assim como Jia et al. (2008) encontraram rutina e isoquercitrina nas folhas de $M$. alba (173). O ácido clorogênico foi o ácido fenólico predominante $(60,5 \%$ - 67,2 \% de ácidos fenólicos detectados e quantificados totais) em todas as três espécies de folhas de amoreira - M. laevigata W., M, alba L., M. nigra L. - em um estudo realizado por Memon et al. (2010), em que o extrato metanólico (80 \%) das folhas de $M$. nigra obteve o maior teor de ácido clorogênico com a técnica de extração por agitação magnética $(81,01 \mathrm{mg} / 100 \mathrm{~g})$ do que as outras espécies (174). Hunyadi et al. (2012) encontraram 3,58 \pm 0,06\% de ácido clorogênico, $1,96 \pm 0,03 \%$ de rutina e 1,20 \pm 0,02\% de isoquercitrina no extrato bruto etanólico (70 \%) das folhas de M. alba (155). Arfan et al. (2012) confirmaram a presença de ácido clorogênico e rutina nos frutos de $M$. nigra, em que os teores de ácido clorogênico em extratos metanólicos $(21,3 \pm 1,55 \mathrm{mg} / \mathrm{g})$ e acetônicos $(23,3 \pm$ $1,1 \mathrm{mg} / \mathrm{g})$ livres de açúcares e os teores de rutina em extratos metanólicos $(39,7 \pm$ 2,12 mg/g) e acetônicos (43,0 $\pm 2,2 \mathrm{mg} / \mathrm{g}$ ) livres de açúcares foram superiores aos teores de ácido clorogênico em extratos metanólicos $(15,0 \pm 0,7 \mathrm{mg} / \mathrm{g})$ e acetônicos $(17,7 \pm 0,8 \mathrm{mg} / \mathrm{g})$ livres de açúcares e os teores de rutina em extratos metanólicos $(26,2 \pm 1,2 \mathrm{mg} / \mathrm{g})$ e acetônicos $(32,3 \pm 1,6 \mathrm{mg} / \mathrm{g})$ livres de açúcares dos frutos de $M$. alba (19). Song et al. (2009) encontraram $86,84 \mathrm{mg} / \mathrm{L}$ de rutina no suco de $M$. nigra Linn., $1,714 \mathrm{mg} / \mathrm{g}$ de rutina em frutos de M. nigra Linn. e 2,268 mg/g de rutina no resíduo após extração do suco de $M$. nigra Linn. do cultivar Shanxiguosang, sendo o segundo maior teor de rutina encontrado entre os 38 cultivars testados. Foi encontrado ainda $2,148 \mathrm{mg} / \mathrm{g}$ de rutina nas folhas de $M$. nigra Linn. do mesmo cultivar (121). Pawlowska et al. (2008) encontraram 32,9 e 3,4 mg/10 g de material seco de rutina e isoquercitrina, respectivamente, nos frutos de $M$. nigra, ambos teores superiores aos frutos de M. alba estudados (175). Gundogdu et al. (2011) estudaram os compostos fenólicos nos frutos de amora negra, branca e vermelha e constatou que ácido clorogênico $(3,106 \pm 0,004 \mathrm{mg} / \mathrm{g}$ massa fresca) foi o fenólico dominante em amora negra, seguido de rutina $(1,423 \pm 0,036 \mathrm{mg} / \mathrm{g}$ massa fresca) 
que, embora seja o fenólico dominante em amoras branca e vermelha, os teores da amora negra foram superiores (176). Os extratos etanólicos dos galhos e casca da raiz de $M$. alba evidenciaram $0,09 \pm 0,02 \mathrm{mg} / \mathrm{g}$ e 0,03 $\pm 0,02 \mathrm{mg} / \mathrm{g}$ de peso seco para rutina, respectivamente; e 0,05 $\pm 0,03 \mathrm{mg} / \mathrm{g}$ e $0,02 \pm 0,02 \mathrm{mg} / \mathrm{g}$ de peso seco para isoquercitrina, respectivamente, nos estudos conduzidos por Chang et al. (2011) (9). A concentração de isoquercitrina nas folhas de $M$. nigra $(2,42 \mathrm{mg} / \mathrm{g})$ foi superior à concentração encontrada por Katsube et al. (2006), que quantificaram os teores dos glicosídeos de flavonol antioxidante lipoproteína de baixa densidade (LDL) no extrato etanólico das folhas de $M$. alba, os quais resultaram em $573 \pm 86 \mathrm{mg} / 100 \mathrm{~g}$ de peso seco para rutina e $194 \pm 26 \mathrm{mg} / 100 \mathrm{~g}$ de peso seco para isoquercitrina (177).

Visando o controle da qualidade de fitoterápicos ou produtos contendo extrato etanólico de $M$. nigra, a validação da metodologia analítica de quantificação do composto majoritário torna-se essencial. A Instrução Normativa $N^{\circ} 4$, de 18 de junho de 2014, exige que esta validação seja realizada como descrito no item materiais e métodos desta dissertação.

\subsubsection{Validação da metodologia de determinação dos teores de ácido clorogênico, rutina e isoquercitrina no extrato padronizado de $M$. nigra por CLAE-DAD}

A validaçao da metodologia analítica para os compostos majoritários presentes em extratos de plantas é essencial para o controle da qualidade dos medicamentos e fitoterápicos. Seguindo as especificações do guia para validação de métodos analíticos e bioanalíticos RE no 899, de 29 de maio de 2003 da Anvisa (133) e pelo guia internacional para o setor industrial, Q2B validação de procedimentos analíticos: Metodologia (141) a validação foi realizada como segue: 


\subsubsection{Seletividade}

É a capacidade que o método possui de medir exatamente um composto na presença de outros componentes tais como impurezas, produtos de degradação e componentes da matriz. Para análise quantitativa (teor) e análise de impurezas, a especificidade pode ser determinada pela comparação dos resultados obtidos de amostras armazenadas sob condições de estresse (por ex. luz, calor, umidade, hidrólise ácida/básica, oxidação) com aquelas que não sofreram estresse, para demonstrar que o resultado do teste não é afetado por esses materiais (133). 0 extrato padronizado de $M$. nigra foi submetido à hidrólise ácida e básica (Figura 21).

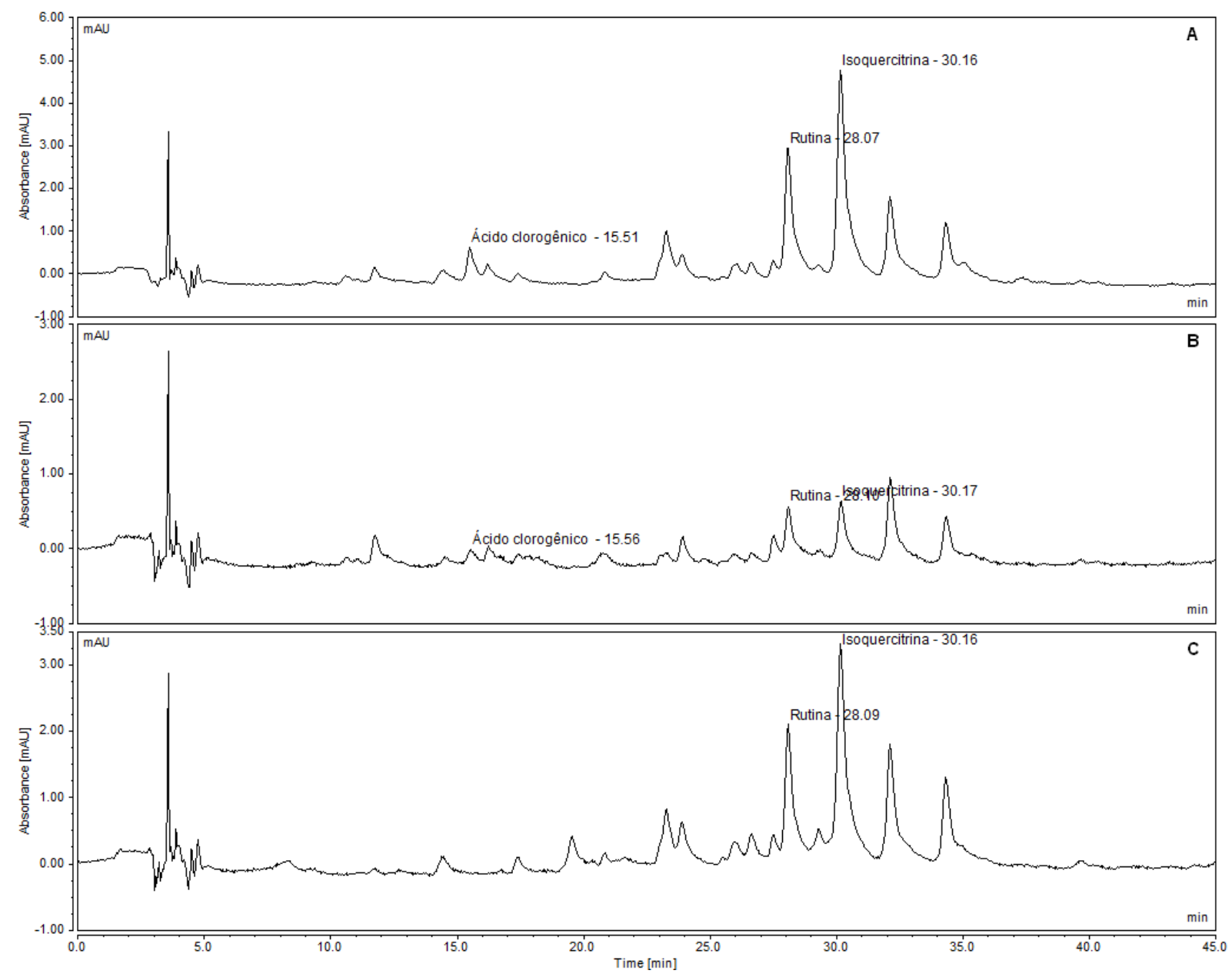

Figura 21 Seletividade do método (A) Cromatograma do extrato padronizado de $M$. nigra; (B) Cromatograma da hidrólise ácida do extrato padronizado de $M$. nigra 2 $\mathrm{mg} / \mathrm{mL}$; (C) Cromatograma da hidrólise básica do extrato padronizado de $M$. nigra 2 $\mathrm{mg} / \mathrm{mL} \lambda=354$. 
Ao sofrer hidrólise ácida, os picos 5, 6, 7, 9 e 10 foram degradados. Os picos 2, 4, 14 e 15 foram reduzidos entre $41 \%$ a $66 \%$ enquanto o pico 8 sofreu pequena redução, de $7 \%$. Já os picos 1 e 11 não tiveram suas áreas reduzidas. Os marcadores ácido clorogênico, rutina e isoquercitrina sofreram redução de 80 \%, 88 \% e $91 \%$ de suas áreas, respectivamente, porém ácido clorogênico e rutina não coeluiram com os produtos de degradação gerados pela hidrólise ácida, demonstrando ser um método seletivo para estes marcadores. A isoquercitrina coeluiu com produtos de degradação, sendo menos seletiva quando submetida à hidrólise ácida, porém manteve seletividade na hidrólise básica (Tabela 9 e Tabela 10).

Tabela 9 - Seletividade do método para o extrato padronizado de $M$. nigra sem processo de hidrólise

\begin{tabular}{ccc}
\hline Pico & Tempo de Retenção $(\mathrm{min})$ & Área (mAU*min) \\
\hline 1 & $11.741 \pm 0.018$ & $0.089 \pm 0.017$ \\
2 & $14.423 \pm 0.000$ & $0.142 \pm 0.007$ \\
3 Acido clorogênico & $15.522 \pm 0.014$ & $0.178 \pm 0.014$ \\
4 & $16.221 \pm 0.016$ & $0.062 \pm 0.002$ \\
5 & $17.392 \pm 0.013$ & $0.068 \pm 0.008$ \\
6 & $20.834 \pm 0.025$ & $0.055 \pm 0.002$ \\
7 & $23.284 \pm 0.022$ & $0.202 \pm 0.020$ \\
8 & $23.900 \pm 0.017$ & $0.109 \pm 0.012$ \\
10 & $26.046 \pm 0.015$ & $0.113 \pm 0.012$ \\
11 & $26.629 \pm 0.008$ & $0.098 \pm 0.009$ \\
12 Rutina & $27.516 \pm 0.012$ & $0.072 \pm 0.011$ \\
13 Isoquercitrina & $28.087 \pm 0.019$ & $1.050 \pm 0.056$ \\
14 & $30.160 \pm 0.006$ & $2.220 \pm 0.093$ \\
15 & $32.113 \pm 0.012$ & $0.696 \pm 0.020$ \\
\hline
\end{tabular}

Os resultados representam a média \pm desvio padrão de três experimentos. 
Tabela 10 - Hidrólise ácida na seletividade do método

\begin{tabular}{ccc}
\hline Pico & Tempo de Retenção $(\mathrm{min})$ & Área $\left(\mathrm{mAU}^{*} \mathrm{~min}\right)$ \\
\hline 1 & $11.720 \pm 0.029$ & $0.098 \pm 0.018$ \\
2 & $14.512 \pm 0.025$ & $0.048 \pm 0.018$ \\
3 Acido clorogênico & $15.538 \pm 0.025$ & $0.035 \pm 0.004$ \\
4 & $16.250 \pm 0.020$ & $0.036 \pm 0.002$ \\
8 & $23.918 \pm 0.005$ & $0.102 \pm 0.015$ \\
11 & $27.528 \pm 0.007$ & $0.073 \pm 0.002$ \\
12 Rutina & $28.101 \pm 0.003$ & $0.127 \pm 0.035$ \\
13 Isoquercitrina & $30.188 \pm 0.025$ & $0.202 \pm 0.069$ \\
14 & $32.117 \pm 0.014$ & $0.310 \pm 0.093$ \\
15 & $34.359 \pm 0.037$ & $0.159 \pm 0.022$ \\
\hline
\end{tabular}

Os resultados representam a média \pm desvio padrão de três experimentos.

A hidrólise básica degradou completamente o ácido clorogênico, bem como os picos 1 e 4 gerando ainda um novo pico $5 \mathrm{a}$ em 19,54 minutos. Os picos 2, 6, 7 e 9 foram reduzidos entre $28 \%$ e $46 \%$ de suas áreas enquanto os picos 11, 14 e 15 sofreram pequenas reduções, de $6 \%$ a $11 \%$. Já os picos 5 , 8 e 10 não tiveram suas áreas reduzidas. Os marcadores rutina e isoquercitrina sofreram redução de $54 \% \mathrm{e}$ $48 \%$ de suas áreas, respectivamente, porém não coeluiram com os produtos de degradação gerados pela hidrólise básica, demonstrando ser um método seletivo. Os dados estão representados na Tabela 11. 
Tabela 11 - Hidrólise básica na seletividade do método

\begin{tabular}{ccc}
\hline Pico & Tempo de Retenção $(\mathrm{min})$ & Área $\left(\mathrm{mAU}{ }^{*} \mathrm{~min}\right)$ \\
\hline 2 & $14.404 \pm 0.037$ & $0.089 \pm 0.011$ \\
5 & $17.378 \pm 0.027$ & $0.069 \pm 0.008$ \\
$5 \mathrm{a}$ & $19.535 \pm 0.027$ & $0.171 \pm 0.025$ \\
6 & $20.828 \pm 0.022$ & $0.033 \pm 0.006$ \\
7 & $23.288 \pm 0.027$ & $0.109 \pm 0.011$ \\
8 & $23.899 \pm 0.013$ & $0.113 \pm 0.006$ \\
9 & $26.015 \pm 0.033$ & $0.081 \pm 0.004$ \\
10 & $26.657 \pm 0.015$ & $0.104 \pm 0.005$ \\
11 & $27.509 \pm 0.033$ & $0.067 \pm 0.010$ \\
12 Rutina & $28.096 \pm 0.010$ & $0.480 \pm 0.78$ \\
13 Isoquercitrina & $30.163 \pm 0.012$ & $1.146 \pm 0.142$ \\
14 & $32.111 \pm 0.014$ & $0.619 \pm 0.092$ \\
15 & $34.326 \pm 0.006$ & $0.354 \pm 0.028$ \\
\hline
\end{tabular}

Os resultados representam a média \pm desvio padrão de três experimentos.

\subsubsection{Linearidade}

É a capacidade de uma metodologia analítica de demonstrar que os resultados obtidos são diretamente proporcionais à concentração do analito na amostra, dentro de um intervalo especificado (133). A equação da reta foi calculada a partir das absorbâncias médias obtidas na faixa de concentração estudada $(0,1$ $10,0 \mu \mathrm{g} / \mathrm{mL})$. O coeficiente de correlação $(r)$, o intercepto, a inclinação, e a soma residual dos quadrados foram determinados utilizado o programa GraphPadPrism ${ }^{\circledR}$ e são demonstrados na Tabela 12.

Segundo a RE ํㅜ 899, de 29 de maio de 2003 e o Guia de orientação para registro de Medicamento Fitoterápico e registro e notificação de Produto Tradicional Fitoterápico, o critério mínimo aceitável do coeficiente de correlação $(r)$ deve ser $\geq$ 0,99 (133), sendo obtidos valores médios de 0,996; 0,997; e 0,998 para ácido clorogênico, rutina e isoquercitrina, respectivamente, nos experimentos. A curva 
obtida demonstrou que os resultados da metodologia analítica são diretamente proporcionais à concentração do analito na amostra. A Figura 22, Figura 23 e Figura 24 representam as curvas de regressão linear obtidas para os três compostos.

Tabela 12 - Linearidade de ácido clorogênico, rutina e isoquercitrina na análise do método por CLAE-DAD

\begin{tabular}{cccccc}
\hline Analito & $\begin{array}{c}\text { Concentração } \\
(\mu \mathrm{g} / \mathrm{mL})\end{array}$ & $r$ & Intercepto & $\begin{array}{c}\text { Inclinação } \\
(\text { slope })\end{array}$ & $\begin{array}{c}\text { Soma } \\
\text { residual dos } \\
\text { quadrados }\end{array}$ \\
\hline Ácido & $0,2-10,0$ & 0,996 & $-0.06468 \pm$ & $0.2278 \pm$ & 0,06818 \\
Clorogênico & & & 0.01757 & 0.00431 & \\
Rutina & $0,1-10,0$ & & $-0,0483 \pm$ & $0,386 \pm$ & 0,0912 \\
& & 0,997 & 0,0215 & 0,00560 & \\
Isoquercitrina & & $0,0746 \pm$ & $0,444 \pm$ & 0,0951 \\
& & & 0,0224 & 0,00584 & \\
\hline
\end{tabular}

Os resultados representam a média \pm desvio padrão de três experimentos.

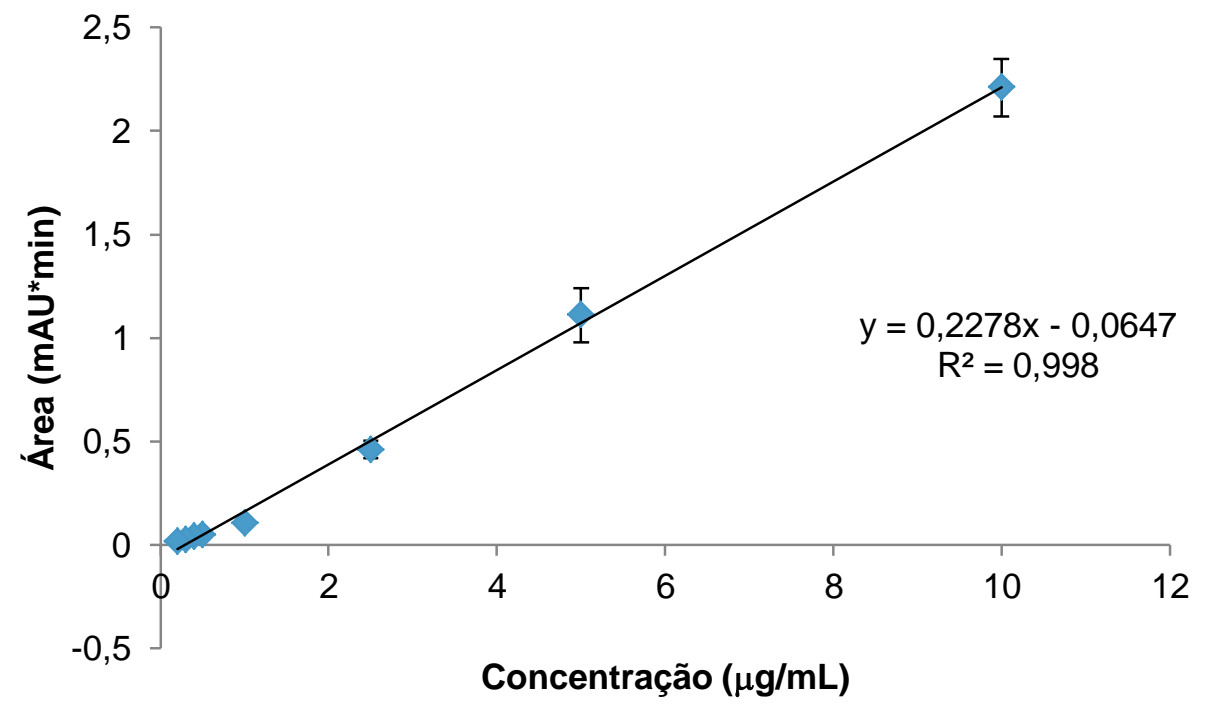

Figura 22 Curva de regressão linear obtida para ácido clorogênico frente ao método proposto. 


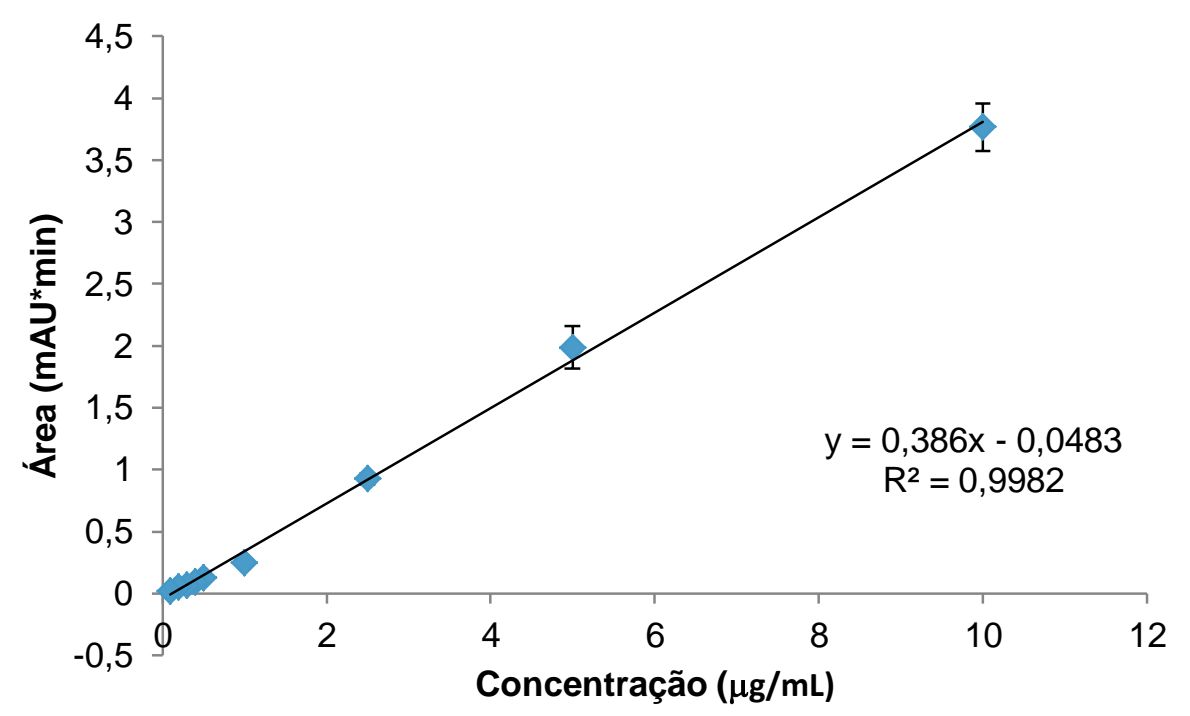

Figura 23 Curva de regressão linear obtida para rutina frente ao método proposto.

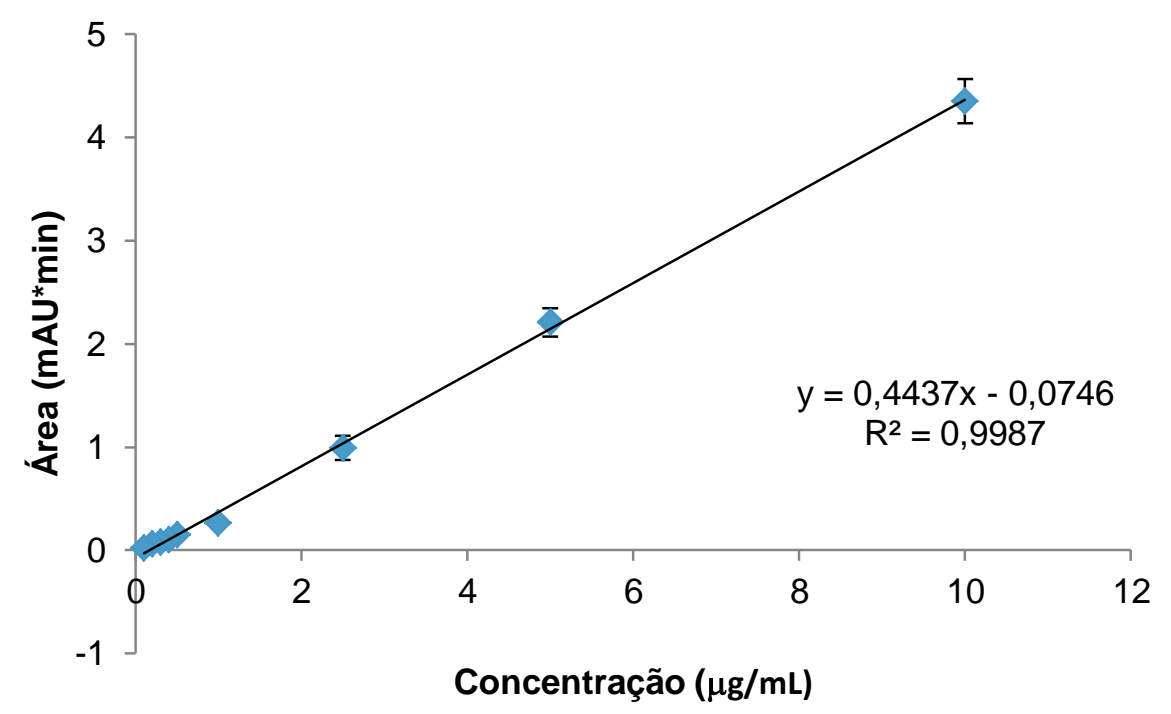

Figura 24 Curva de regressão linear obtida para isoquercitrina frente ao método proposto.

\subsubsection{Precisão}

A repetibilidade representa a concordância entre os resultados de medições sucessivas de um mesmo método, efetuadas sob as mesmas condições de medição, chamadas condições de repetibilidade: mesmo procedimento, analista, 
instrumento usado sob as mesmas condições, local, repetições em um curto intervalo de tempo (178). É normalmente expressa como o desvio padrão relativo (DPR) percentual para um número estatisticamente significativo de amostras e pode ser determinada a partir de um mínimo de seis determinações a $100 \%$ da concentração teste ou concentração alvo (179).

$\mathrm{Na}$ repetibilidade avaliada a partir da análise de 6 determinações de igual concentração $(2 \mathrm{mg} / \mathrm{mL})$, os desvios padrões relativos médios encontrados foram de $10,20 \% ; 11,73 \%$ e 8,33 \% para ácido clorogênico, rutina e isoquercitrina, respectivamente, demonstrados na Tabela 13.

Tabela 13 - Repetibilidade do método para quantificação de ácido clorogênico, rutina e isoquercitrina em M. nigra

\begin{tabular}{lll}
\hline Marcador $^{1}$ & Concentração $(\mu \mathrm{g} / \mathrm{mL})$ & DPR (\%) \\
\hline Ácido Clorogênico & $1,15 \pm 0,12$ & 10,20 \\
Rutina & $2,89 \pm 0,34$ & 11,73 \\
Isoquercitrina & $4,99 \pm 0,42$ & 8,33
\end{tabular}

Os resultados representam a média \pm desvio padrão.

${ }^{1}$ Seis replicatas foram analisadas no mesmo dia.

DPR=Desvio Padrão Relativo.

A precisão intermédia é o resultado de variações intralaboratoriais devido a eventos aleatórios como dias diferentes, os analistas, equipamentos, entre outros (179). O objetivo da validação da precisão intermediária é verificar que no mesmo laboratório o método fornecerá os mesmos resultados (178).

$\mathrm{Na}$ análise inter-dia foram encontradas variações de 6,99 \%; 3,59 \% e 3,99 \% para ácido clorogênico, rutina e isoquercitrina, respectivamente, demonstrados na Tabela 14. 
Tabela 14 - Precisão inter-dia do método para quantificação de ácido clorogênico, rutina e isoquercitrina em $M$. nigra

\begin{tabular}{|c|c|c|}
\hline Marcador $^{1}$ & Concentração $(\mu \mathrm{g} / \mathrm{mL})$ & DPR (\%) \\
\hline Ácido Clorogênico & $0,99 \pm 0,07$ & 6,99 \\
\hline Rutina & $2,85 \pm 0,10$ & 3,59 \\
\hline Isoquercitrina & $5,13 \pm 0,20$ & 3,99 \\
\hline
\end{tabular}

Estes resultados são indicativos de boa precisão já que a literatura não admite valores de desvio padrão relativo superiores a $15 \%$ de acordo com o Guia de orientação para registro de Medicamento Fitoterápico e registro e notificação de Produto Tradicional Fitoterápico (132).

\subsubsection{Limite de Detecção (LD)}

O limite de detecção (LD) é definido como a menor concentração de um analito numa amostra que pode ser detectada, não quantificada. É um teste de limite que especifica se um analito está acima ou abaixo de um determinado valor ou não (179).

Os limites de detecção encontrados para ácido clorogênico, rutina e isoquercitrina determinados pelo método baseado nos parâmetros da curva analítica, em que esta contém os compostos de interesse na faixa de concentrações próximas ao limite de detecção - 0,1-0,5 $\mu \mathrm{g} / \mathrm{mL}$ para rutina e isoquercitrina e 0,2-1,0 para ácido clorogênico -, estão demonstrados na Tabela 15. 
Tabela 15 - Limites de detecção calculados para ácido clorogênico, rutina e isoquercitrina segundo o método baseado em parâmetros da curva analítica

\begin{tabular}{ccc}
\hline Marcador & Concentrações $(\mu \mathrm{g} / \mathrm{mL})$ & $\begin{array}{c}\text { Limite de Detecção } \\
(\mu \mathrm{g} / \mathrm{mL})\end{array}$ \\
\hline Ácido clorogênico & $0,2-1,0$ & 0,11 \\
Rutina & $0,1-0,5$ & 0,12 \\
Isoquercitrina & & 0,10 \\
\hline
\end{tabular}

5.3.1.5. Limite de Quantificação (LQ)

O limite de quantificação (LQ) é definido como a menor concentração de um analito numa amostra que pode ser determinada com precisão e exatidão aceitáveis de acordo com as condições operacionais indicadas do método. $\mathrm{O}$ método utilizado para determinar LQ deve ser documentado e suportado, e um número adequado de amostras devem ser analisadas no limite para validar o nível (179).

Os limites de quantificação encontrados para ácido clorogênico, rutina e isoquercitrina determinados pelo método baseado nos parâmetros da curva analítica, em que esta contém a concentração correspondente ao $L Q$, estão demonstrados na Tabela 16.

Tabela 16 - Limites de quantificação encontrados para ácido clorogênico, rutina e isoquercitrina segundo o método baseado em parâmetros da curva analítica

\begin{tabular}{ccc}
\hline Marcador & Concentrações $(\mu \mathrm{g} / \mathrm{mL})$ & $\begin{array}{c}\text { Limite de Quantificação } \\
(\mu \mathrm{g} / \mathrm{mL})\end{array}$ \\
\hline Ácido clorogênico & $0,2-1,0$ & 0,34 \\
Rutina & $0,1-0,5$ & 0,35 \\
Isoquercitrina & & 0,30 \\
\hline
\end{tabular}

O problema do cálculo do LD e LQ pode ser resolvido através da utilização do método baseado nos parâmetros da curva analítica, que é estatisticamente mais 
confiável, porém a determinação do LQ representa um compromisso entre a concentração, a precisão e a exatidão exigidas, ou seja, quando o nível de concentração do LQ decresce, a medição torna-se menos precisa. Uma concentração maior deve ser registrada pelo $L Q$ se houver necessidade de maior precisão (178). Em análise segundo o método visual, foi possível distinguir entre ruído e sinal analítico pela visualização da menor concentração que pode ser quantificável com confiança através de 7 (sete) repetições de cada concentração $(0,10$ e $0,075 \mu \mathrm{g} / \mathrm{mL})$, em que o limite de quantificação experimental, o desvio padrão e desvio padrão relativo (DPR) foram calculados para cada analito e estão demonstrados na Tabela 17.

Tabela 17 - Limite de quantificação determinado para rutina e isoquercitrina segundo o método visual experimental

\begin{tabular}{ccc}
\hline Concentração $(\mu \mathrm{g} / \mathrm{mL})$ & Área \pm desvio padrão & DPR $(\%)$ \\
\hline 0,1 & Rutina & \\
0,075 & $0,026 \pm 0,002$ & 8,853 \\
& $0,015 \pm 0,003$ & 20,381 \\
0,1 & Isoquercitrina & 7,464 \\
0,075 & $0,033 \pm 0,002$ & 33,347 \\
\hline
\end{tabular}

DPR=Desvio Padrão Relativo.

O ácido clorogênico não pode ser quantificado com confiança nas concentrações de 0,1 e $0,075 \mu \mathrm{g} / \mathrm{mL}$ no comprimento de onda $354 \mathrm{~nm}$, porém em $330 \mathrm{~nm}$, onde possui maior absorção, este analito pode ser quantificado com precisão na concentração de $0,075 \mu \mathrm{g} / \mathrm{mL}$. Os flavonoides rutina e isoquercitrina foram detectados na menor concentração avaliada, de 0,075 $\mu \mathrm{g} / \mathrm{mL}$ (Figura 25), porém devido ao elevado desvio padrão relativo indicativo de baixa precisão, não podem ser quantificados com confiança. Na concentração de 0,1 $\mu \mathrm{g} / \mathrm{mL}$ os desvios padrões relativos se encontram abaixo de $10 \%$, indicativos de boa precisão. Em concentrações inferiores a $0,1 \mu \mathrm{g} / \mathrm{mL}$ torna-se menos confiável a distinção entre ruído e sinal analítico. Por este motivo, os limites de detecção e quantificação 
estabelecidos para rutina e isoquercitrina foram de 0,075 e $0,1 \mu \mathrm{g} / \mathrm{mL}$, respectivamente.

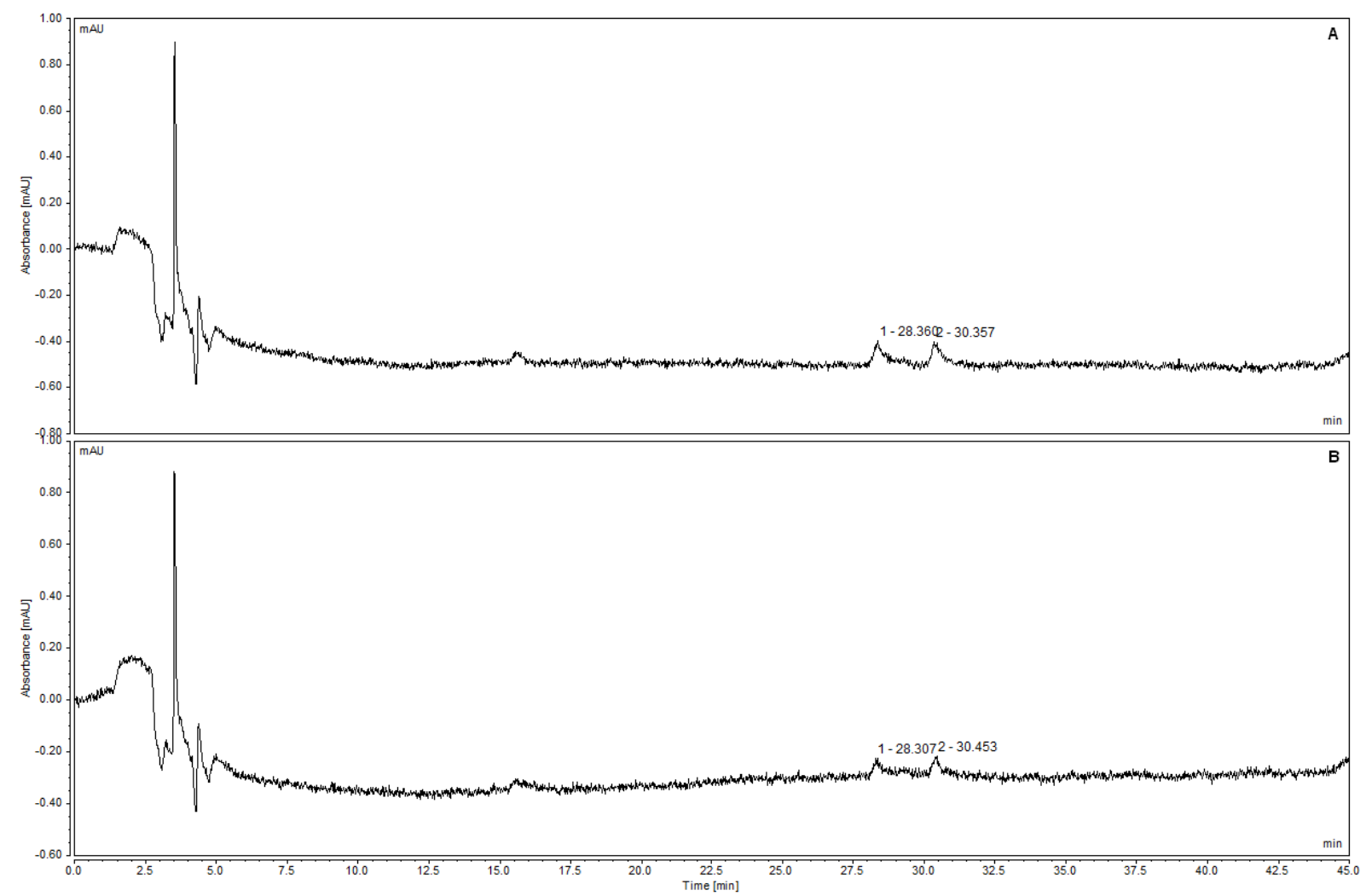

Figura 25 Limite de quantificação pelo método visual. (A) 1-rutina e 2-isoquercitrina $0,1 \mu \mathrm{g} / \mathrm{mL}$; (B) 1-rutina e 2-isoquercitrina $0,075 \mu \mathrm{g} / \mathrm{mL} \lambda=354 \mathrm{~nm}$.

Alguns valores de limites de detecção e quantificação descritos na literatura para os polifenois avaliados estão demonstrados na Tabela 18. Os achados do presente trabalho foram similares aos encontrados por Kim et al. (2015) (180) para ácido clorogênico e Bilbao et al. (181) para isoquercitrina. Os limites de detecção e quantificação do presente trabalho demonstraram que o método proposto possui boa sensibilidade ao detectar e quantificar os polifenóis estudados. 
Tabela 18 - Limites de detecção e quantificação descritos na literatura para ácido clorogênico, rutina e isoquercitrina

\begin{tabular}{cccc}
\hline & $\mathrm{LD}$ & $\mathrm{LQ}$ & Fonte \\
\hline \multirow{4}{*}{ Ácido clorogênico } & $0,36 \mu \mathrm{g} / \mathrm{mL}$ & $1,08 \mu \mathrm{g} / \mathrm{mL}$ & $(182)$ \\
& $0,10 \mu \mathrm{g} / \mathrm{mL}$ & $0,30 \mu \mathrm{g} / \mathrm{mL}$ & $(180)$ \\
& $0,023 \mu \mathrm{g} / \mathrm{mL}$ & $0,076 \mu \mathrm{g} / \mathrm{mL}$ & $(183)$ \\
& $14,95479 \mu \mathrm{g} / \mathrm{mL}$ & $45,31756 \mu \mathrm{g} / \mathrm{mL}$ & $(184)$ \\
\hline \multirow{2}{*}{ Rutina } & $0,09 \mu \mathrm{g} / \mathrm{mL}$ & $0,29 \mu \mathrm{g} / \mathrm{mL}$ & $(185)$ \\
& $0,04 \mathrm{mg} / \mathrm{L}$ & $0,15 \mathrm{mg} / \mathrm{L}$ & $(181)$ \\
& $0,025 \mu \mathrm{g} / \mathrm{mL}$ & $0,50 \mu \mathrm{g} / \mathrm{mL}$ & $(186)$ \\
& $0,19 \mu \mathrm{g} / \mathrm{mL}$ & $0,60 \mu \mathrm{g} / \mathrm{mL}$ & $(140)$ \\
\hline \multirow{3}{*}{ Isoquercitrina } & $0,02 \mu \mathrm{g} / \mathrm{mL}$ & $0,07 \mu \mathrm{g} / \mathrm{mL}$ & $(187)$ \\
& $0,57 \mu \mathrm{g} / \mathrm{mL}$ & $1,88 \mu \mathrm{g} / \mathrm{mL}$ & $(188)$ \\
& $0,08 \mathrm{mg} / \mathrm{L}$ & $0,14 \mathrm{mg} / \mathrm{L}$ & $(181)$
\end{tabular}

LD=limite de detecção; LD=limite de quantificação.

\subsubsection{Exatidão}

Exatidão é a proximidade dos resultados do ensaio obtidos pelo método analítico ao verdadeiro valor (179). A exatidão é sempre considerada dentro de certos limites, a um dado nível de confiança, os quais podem ser estreitos em níveis de concentração elevados e mais amplos em níveis de traços (178). Exatidão deve ser avaliada utilizando um mínimo de 9 (nove) determinações sobre um mínimo de 3 (três) níveis de concentração cobrindo a faixa especificada (3 concentrações/3 replicatas cada do procedimento analítico total) e pode ser documentada como percentual de recuperação pelo ensaio de quantidade conhecida de analito adicionado na amostra ou como a diferença entre a média e o valor real aceito (141).

A exatidão do método proposto para a concentração teórica de ácido clorogênico de 0,$75 ; 1,00$ e $1,25 \mu \mathrm{g} / \mathrm{mL}$ foi de $97,49 \% \pm 7,74 ; 91,40 \% \pm 5,69$ e $86,49 \% \pm 4,50$, respectivamente, demonstrada na Tabela 19 . 
Tabela 19 - Exatidão do método de adição de ácido clorogênico por CLAE-DAD

\begin{tabular}{ccccc}
\hline $\begin{array}{c}\text { Concentração } \\
(\%)\end{array}$ & $\begin{array}{c}\text { Ácido } \\
\text { clorogênico } \\
\text { adicionado } \\
(\mu \mathrm{g} / \mathrm{mL})\end{array}$ & $\begin{array}{c}\text { Ácido } \\
\text { clorogênico } \\
\text { encontrado } \\
(\mu \mathrm{g} / \mathrm{mL})\end{array}$ & $\begin{array}{c}\text { Exatidão } \\
(\%)\end{array}$ & EPR (\%) \\
\hline 72 & 0,75 & $0,73 \pm 0,06$ & $97,49 \pm 7,74$ & $-2,51$ \\
95 & 1,00 & $0,91 \pm 0,06$ & $91,40 \pm 5,69$ & $-8,60$ \\
117 & 1,25 & $1,08 \pm 0,06$ & $86,49 \pm 4,50$ & $-13,51$
\end{tabular}

Os resultados representam a médiatdesvio padrão de três ensaios.

EPR=Erro Padrão Relativo.

A exatidão do método proposto para a concentração teórica de rutina de 2,02; 2,52 e $3,02 \mu \mathrm{g} / \mathrm{mL}$ foi de $98,44 \% \pm 2,33 ; 97,07 \% \pm 6,03$ e $95,01 \% \pm 3,81$, respectivamente, demonstrada na Tabela 20.

Tabela 20 - Exatidão do método de adição de rutina por CLAE-DAD

\begin{tabular}{ccccc}
\hline $\begin{array}{c}\text { Concentração } \\
(\%)\end{array}$ & $\begin{array}{c}\text { Rutina } \\
\text { adicionada } \\
(\mu \mathrm{g} / \mathrm{mL})\end{array}$ & $\begin{array}{c}\text { Rutina } \\
\text { encontrada } \\
(\mu \mathrm{g} / \mathrm{mL})\end{array}$ & $\begin{array}{c}\text { Recuperação } \\
(\%)\end{array}$ & EPR (\%) \\
\hline 80 & 2,02 & $1,98 \pm 0,05$ & $98,44 \pm 2,33$ & $-1,56$ \\
99 & 2,52 & $2,44 \pm 0,15$ & $97,07 \pm 6,03$ & $-2,93$ \\
119 & 3,02 & $2,86 \pm 0,11$ & $95,01 \pm 3,81$ & $-4,99$ \\
\hline
\end{tabular}

Os resultados representam a média_desvio padrão de três ensaios.

EPR=Erro Padrão Relativo.

A exatidão do método proposto para a concentração teórica de isoquercitrina de 3,$92 ; 4,92$ e $5,92 \mu \mathrm{g} / \mathrm{mL}$ foi de $102,06 \% \pm 1,85 ; 102,92 \% \pm 4,64$ e $103,09 \% \pm$ 5,89 , respectivamente, demonstrada na Tabela 21. 
Tabela 21 - Exatidão do método de adição de isoquercitrina por CLAE-DAD

\begin{tabular}{ccccc}
\hline $\begin{array}{c}\text { Concentração } \\
(\%)\end{array}$ & $\begin{array}{c}\text { Isoquercitrina } \\
\text { adicionada } \\
(\mu \mathrm{g} / \mathrm{mL})\end{array}$ & $\begin{array}{c}\text { Isoquercitrina } \\
\text { encontrada } \\
(\mu \mathrm{g} / \mathrm{mL})\end{array}$ & $\begin{array}{c}\text { Recuperação } \\
(\%)\end{array}$ & EPR (\%) \\
\hline 81 & 3,92 & $4,00 \pm 0,07$ & $102,06 \pm 1,85$ & 2,06 \\
102 & 4,92 & $5,06 \pm 0,23$ & $102,92 \pm 4,64$ & 2,92 \\
122 & 5,92 & $6,10 \pm 0,35$ & $103,09 \pm 5,89$ & 3,09 \\
\hline
\end{tabular}

Os resultados representam a média \pm desvio padrão de três ensaios.

EPR=Erro Padrão Relativo.

Estes resultados são indicativos de boa exatidão, já que os valores de erro padrão relativo estão dentro da faixa de $\pm 15 \%$.

\subsubsection{Robustez}

A robustez de um método é a sua capacidade de permanecer inalterado por pequenas variações deliberadas dos parâmetros do método e é avaliada através da alteração de parâmetros do método como porcentagem do solvente orgânico, pH da fase móvel, força iônica, diferentes colunas de CLAE, temperatura da coluna e fluxo (179).

Os resultados demonstram que não houve mudanças nos tempos de retenção com a mudança do comprimento de onda para os marcadores estudados, porém houve mudança esperada nas áreas obtidas, já que o ácido clorogênico possui maior absorção em $330 \mathrm{~nm}$ do que nos demais comprimentos de onda (280 $\mathrm{nm}$ e $354 \mathrm{~nm}$ ) e os flavonoides rutina e isoquercitrina possuem maior absorção em $354 \mathrm{~nm}$ do que nos demais comprimentos de onda (280 nm e $330 \mathrm{~nm}$ ), obtendo assim uma maior área dos picos nos comprimentos de onda respectivos em que cada analito possui maior absorção (Figura 26). 

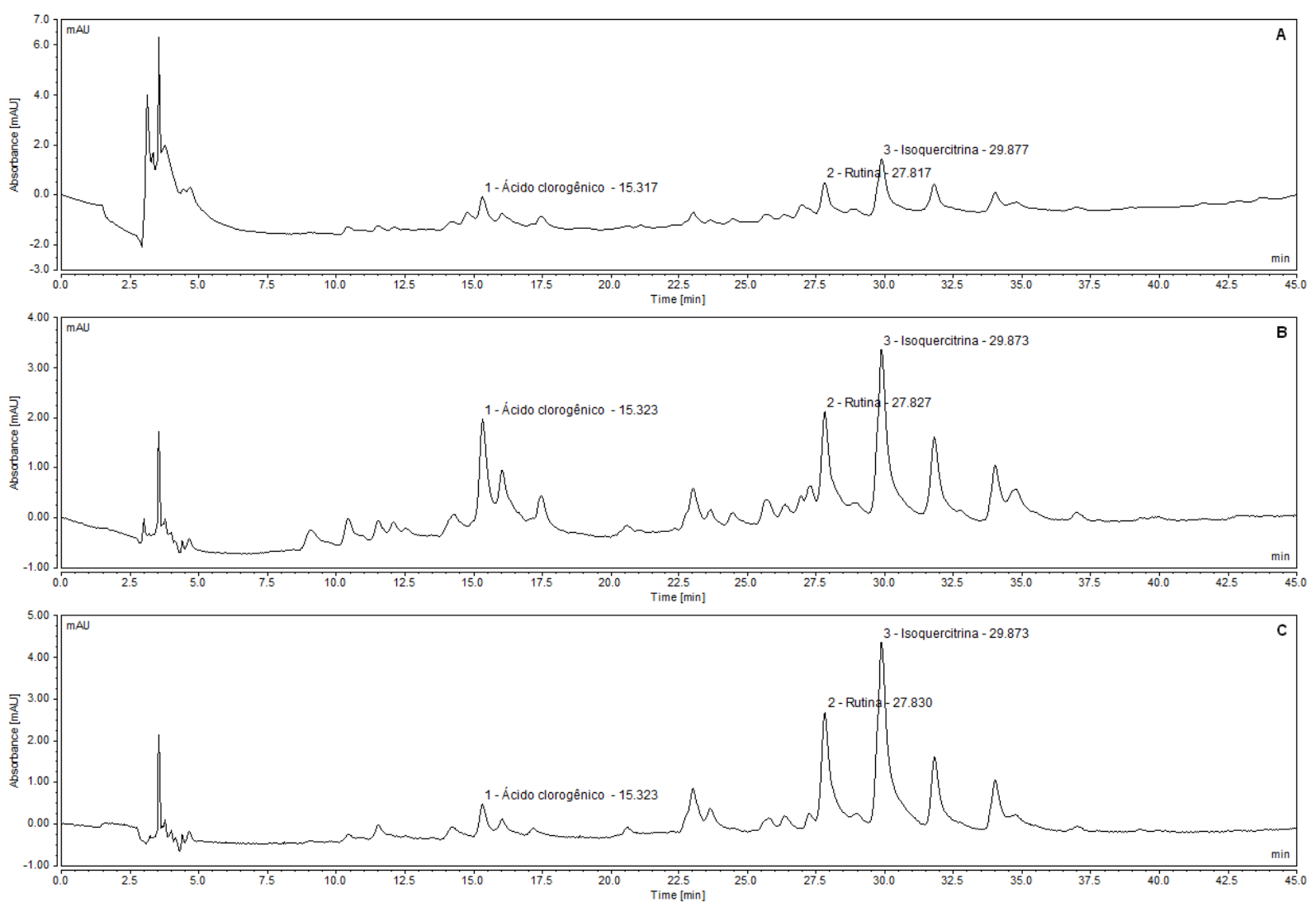

Figura 26 Alteração do parâmetro comprimento de onda para robustez frente ao método proposto. (A) $\lambda=280 \mathrm{~nm}$; (B) $\lambda=330 \mathrm{~nm}$; (C) $\lambda=354 \mathrm{~nm}$. $\mathrm{T}=25^{\circ} \mathrm{C}$; Fluxo: 0,5 $\mathrm{mL} / \mathrm{min}$.

O aumento de temperatura provocou deslocamento dos picos, alterando, assim, os tempos de retenção e as áreas (Figura 27). Temperaturas mais elevadas provocam eluição mais rápida dos compostos, como esperado. Foi observado aumento na área do pico da rutina em $35^{\circ} \mathrm{C}$, que pode ser explicada pela coeluição de seu pico com picos próximos referentes a outros compostos presentes no extrato. Houve uma diminuição da área dos picos de todos os marcadores na temperatura mais elevada, de $45^{\circ} \mathrm{C}$, que pode ser explicada pela possível degradação destes frente a elevadas temperaturas. Os espectros UV dos marcadores estão demontrados na Figura 28, Figura 29 e Figura 30 para as variações de temperaturas na avaliação da robustez do método. 

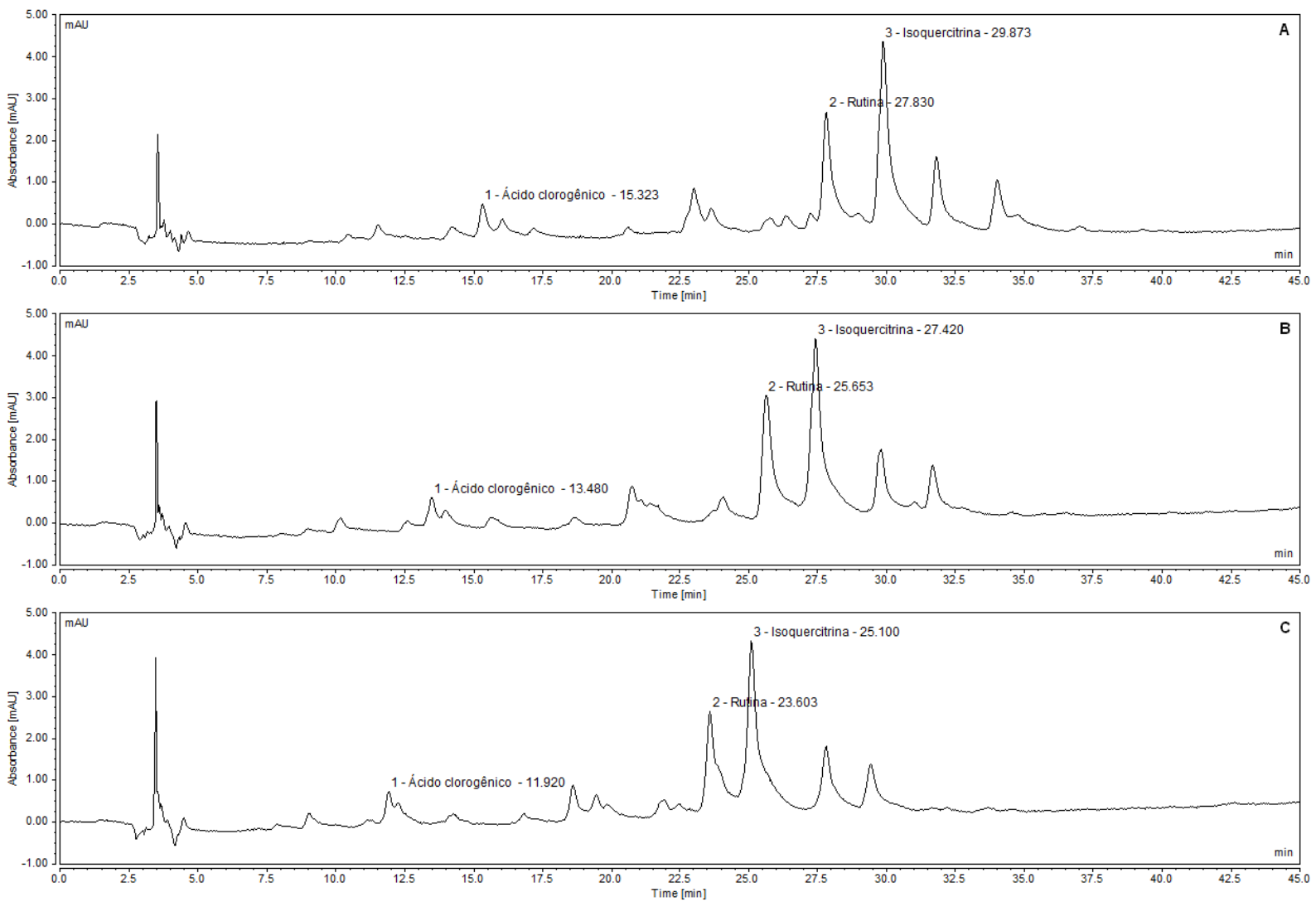

Figura 27 Alteração do parâmetro temperatura para robustez frente ao método proposto. (A) temperatura $25^{\circ} \mathrm{C}$; (B) temperatura $35^{\circ} \mathrm{C}$; (C) temperatura $45^{\circ} \mathrm{C}$. Fluxo: $0,5 \mathrm{~mL} / \mathrm{min} ; \lambda=354 \mathrm{~nm}$. 

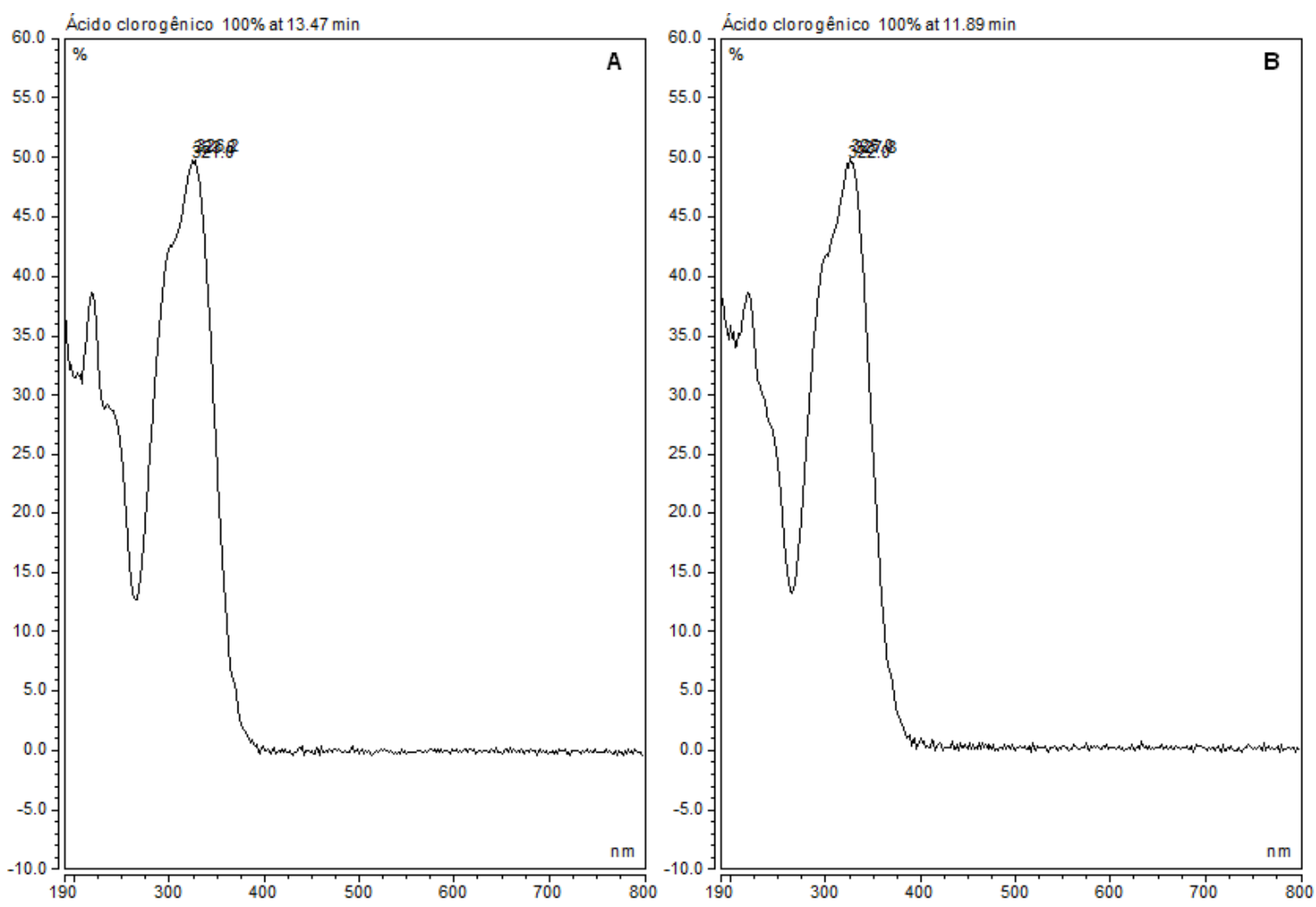

Figura 28 Espectro UV de ácido clorogênico na variação da temperatura na avaliação da robustez frente ao método proposto $(A) 35^{\circ} \mathrm{C}$; (B) $45^{\circ} \mathrm{C}$.
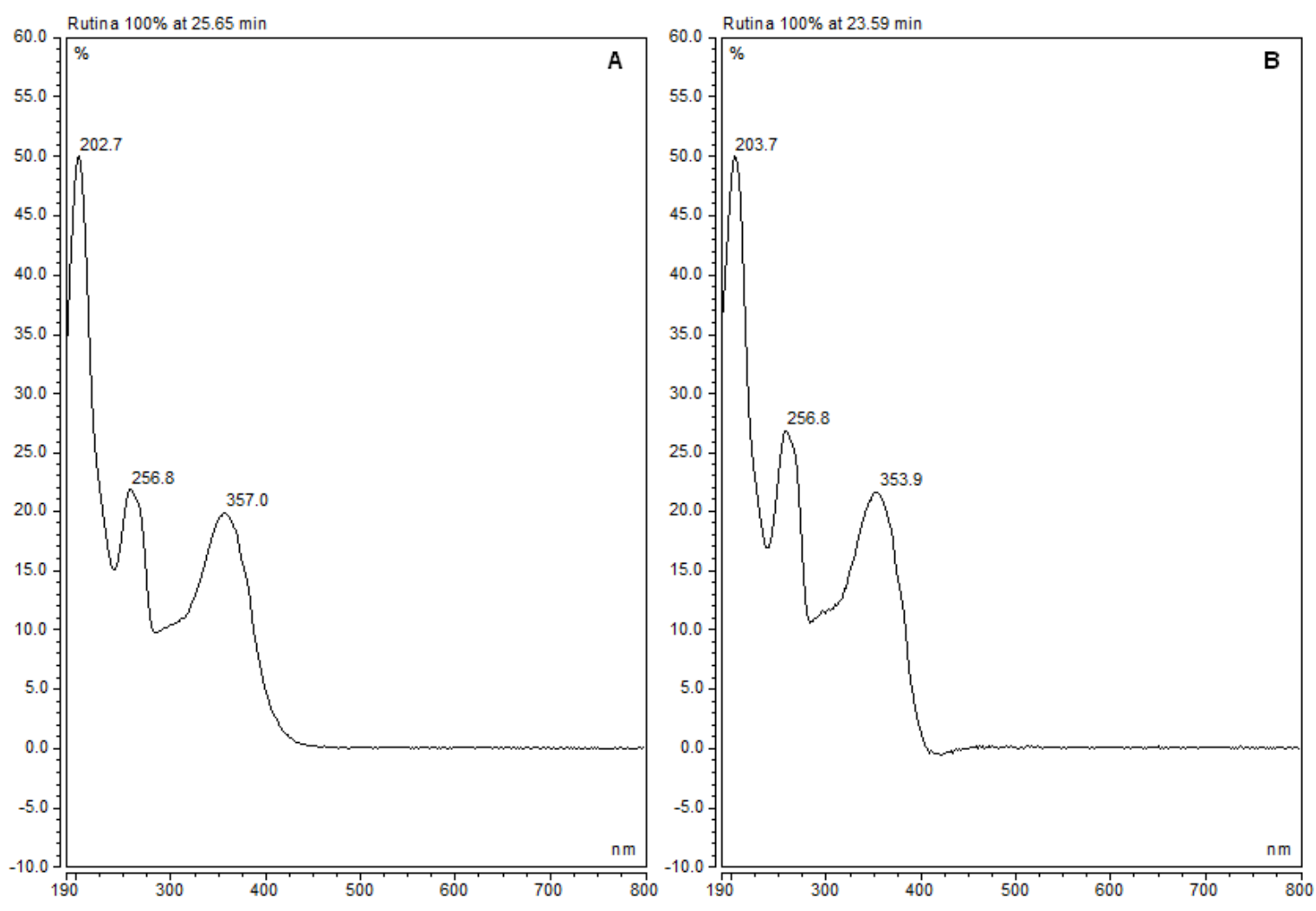

Figura 29 Espectro UV de rutina na variação da temperatura na avaliação da robustez frente ao método proposto $(A) 35^{\circ} \mathrm{C}$; (B) $45^{\circ} \mathrm{C}$. 

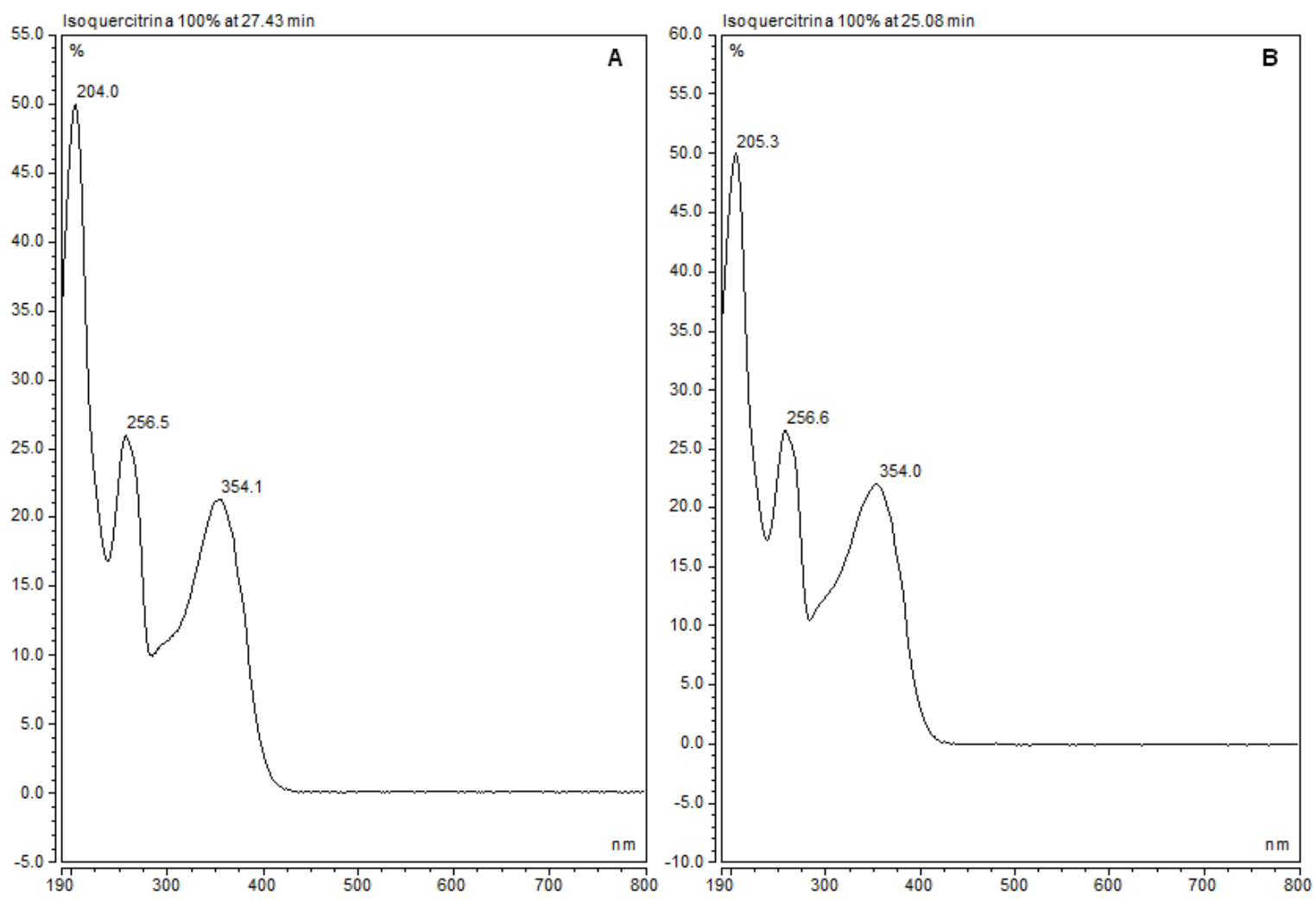

Figura 30 Espectro UV de isoquercitrina na variação da temperatura na avaliação da robustez frente ao método proposto (A) $35^{\circ} \mathrm{C}$; (B) $45^{\circ} \mathrm{C}$.

A alteração de fluxo provocou deslocamento dos picos, alterando, assim, os tempos de retenção e as áreas (Figura 31). Fluxos mais elevados provocam eluição mais rápida dos compostos, como esperado. $\mathrm{O}$ ácido clorogênico não foi detectado no fluxo de $0,3 \mathrm{~mL} / \mathrm{min}$, o que torna este método menos robusto para este marcador em particular, porém possui robustez para os outros parâmetros avaliados (Figura 32). Foi observado um aumento de área para rutina e isoquercitrina com redução do fluxo para $0,3 \mathrm{~mL} / \mathrm{min}$ sem alterar a pureza do pico, como pode ser observado pelos espectros UV (Figura 33 e Figura 34), o que indica que não houve coeluição com outros picos próximos a eles. Houve redução de área de todos os analitos com o aumento do fluxo para $0,7 \mathrm{~mL} / \mathrm{min}$. O aumento e redução de área de pico observados com a redução e aumento de fluxo, respectivamente, são explicados pela seguinte fórmula:

$$
A i=\frac{k i m i}{Q}
$$


Onde:

$A_{i}$ é a resposta da área pelo detector ao composto i

$\mathrm{k}_{\mathrm{i}}$ é o fator de resposta do detector (sensibilidade do detector ao composto i)

$m_{i}$ é a massa do composto i injetada

Q é o fluxo

Há uma relação entre o fluxo e a área obtida, em que o aumento do fluxo resulta em um decréscimo da resposta do detector (189).

Os resultados estão demontrados na Tabela 22, Tabela 23 e Tabela 24.
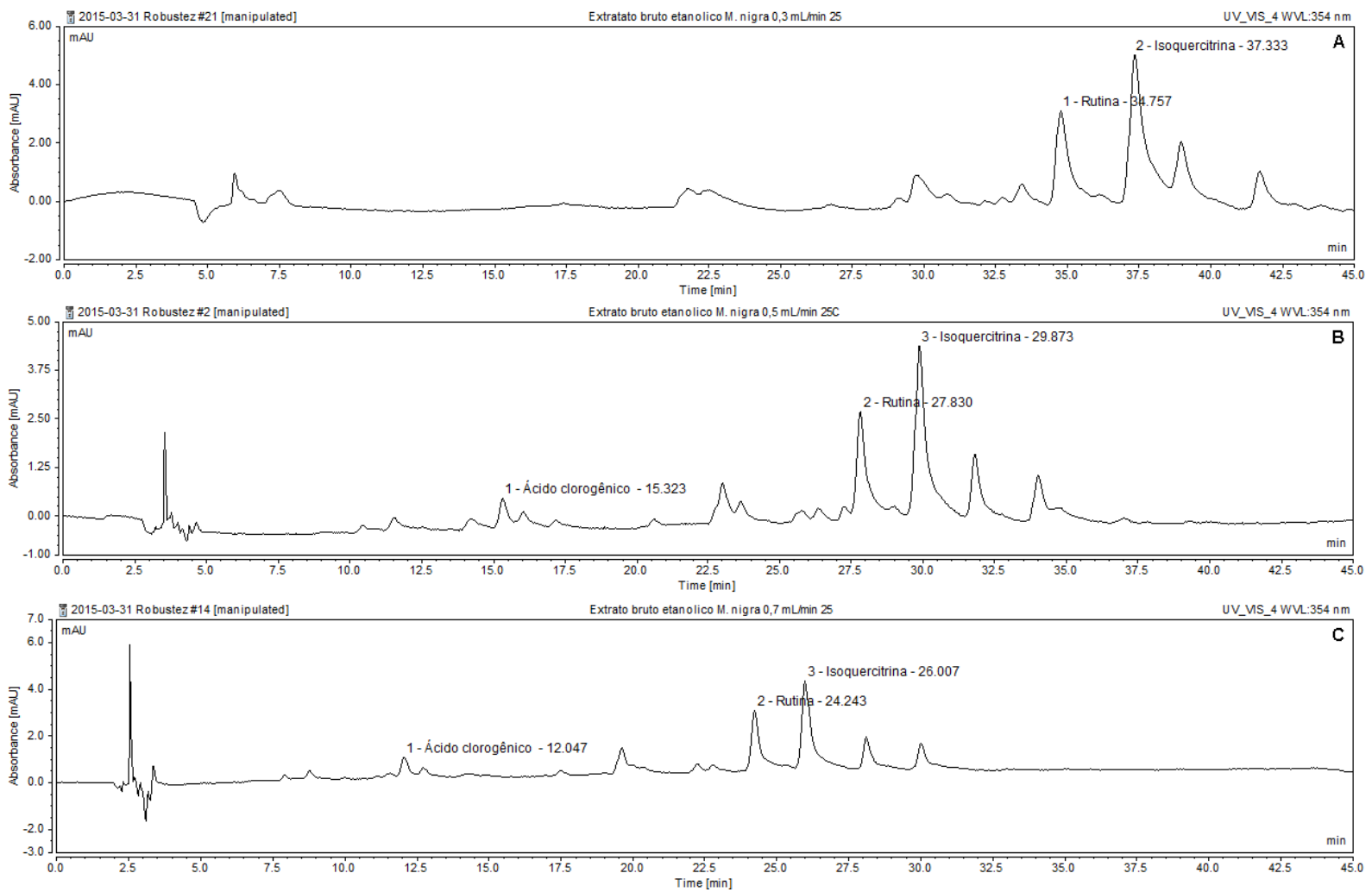

Figura 31 Alteração do parâmetro fluxo para robustez frente ao método proposto. $(A)$ fluxo $0,3 \mathrm{~mL} / \mathrm{min}$; (B) fluxo $0,5 \mathrm{~mL} / \mathrm{min}$; (C) fluxo $0,7 \mathrm{~mL} / \mathrm{min}$. $T=25^{\circ} \mathrm{C} ; \lambda=354 \mathrm{~nm}$. 


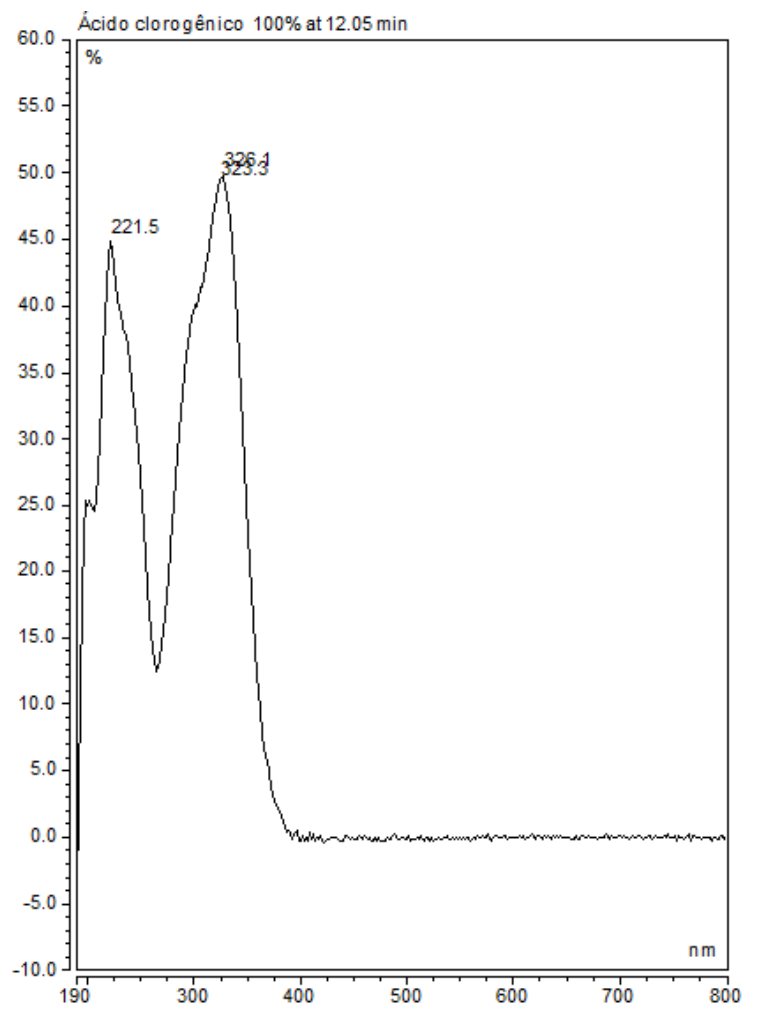

Figura 32 Espectro UV do ácido clorogênico na variação do fluxo na avaliação da robustez frente ao método proposto. Fluxo: $0,7 \mathrm{~mL} / \mathrm{min}$.
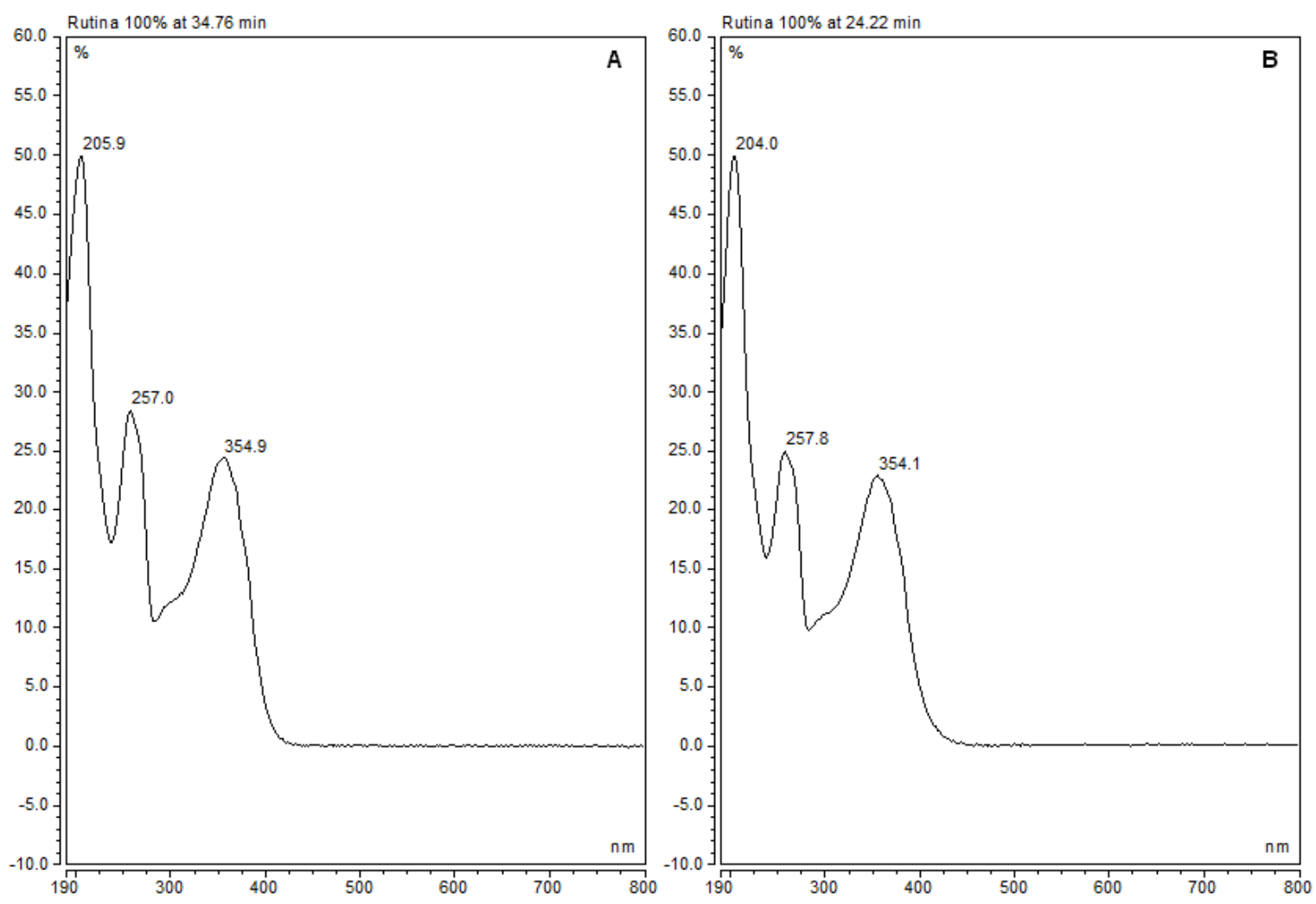

Figura 33 Espectro UV da rutina na variação do fluxo na avaliação da robustez frente ao método proposto. (A) $0,3 \mathrm{~mL} / \mathrm{min}$; (B) $0,7 \mathrm{~mL} / \mathrm{min}$. 

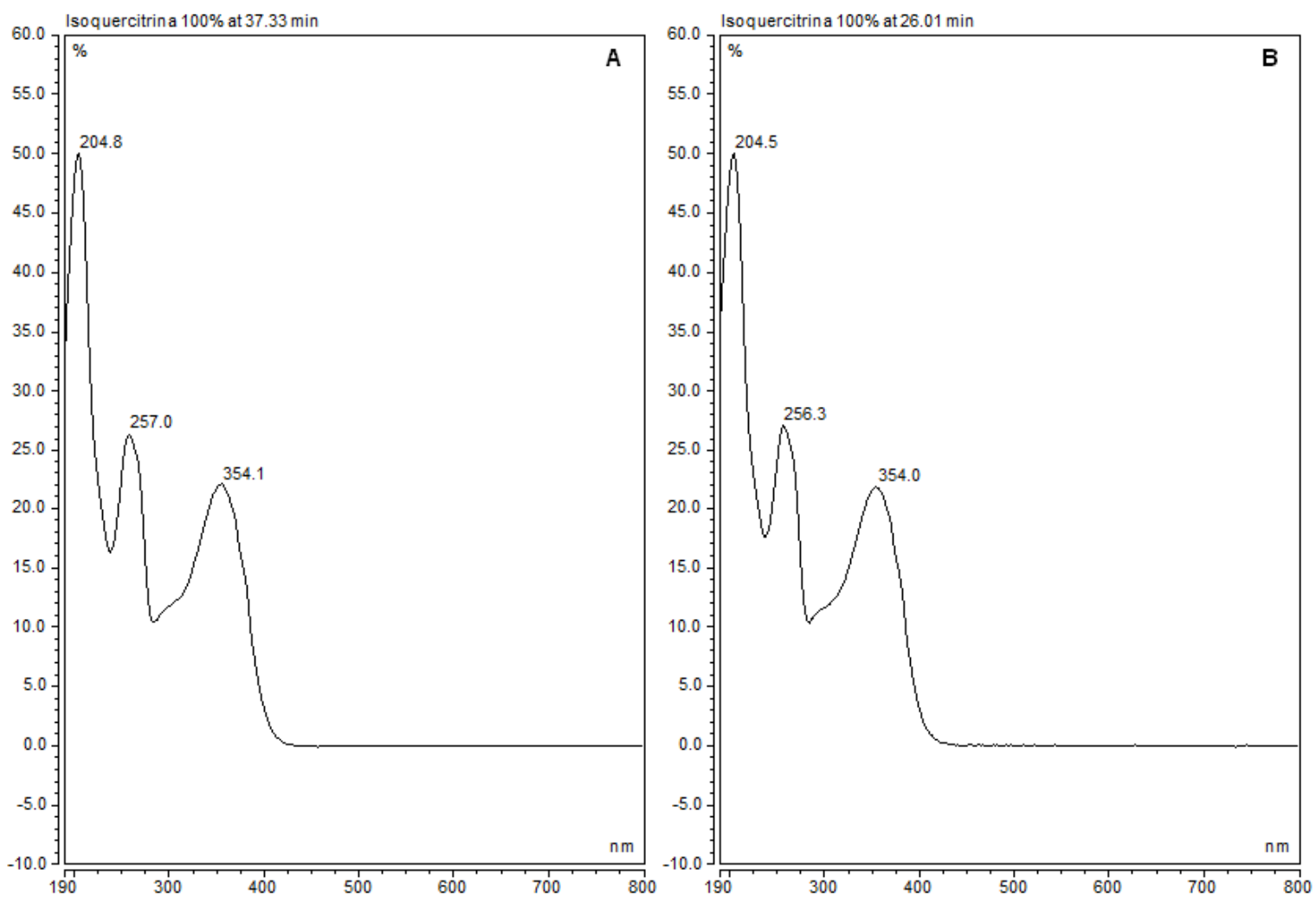

Figura 34 Espectro UV da isoquercitrina na variação do fluxo na avaliação da robustez frente ao método proposto. (A) 0,3 $\mathrm{mL} / \mathrm{min}$; (B) $0,7 \mathrm{~mL} / \mathrm{min}$.

Tabela 22 - Resultados das variações de comprimento de onda, temperatura e fluxo para ácido clorogênico no ensaio de robustez

\begin{tabular}{ccc}
\hline Parâmetros avaliados & Tempo de Retenção $(\mathrm{min})$ & Área $\left(\mathrm{mAU}^{*} \mathrm{~min}\right)$ \\
\hline Comprimento de onda $(\mathrm{nm})$ & $15,29 \pm 0,02$ & $0,26 \pm 0,01$ \\
280 & $15,30 \pm 0,02$ & $0,57 \pm 0,00$ \\
330 & $15,29 \pm 0,03$ & $0,17 \pm 0,01$ \\
354 & & \\
Temperatura $\left({ }^{\circ} \mathrm{C}\right)$ & $15,30 \pm 0,02$ & $0,17 \pm 0,01$ \\
25 & $13,47 \pm 0,01$ & $0,14 \pm 0,00$ \\
35 & $11,90 \pm 0,01$ & $0,12 \pm 0,00$ \\
45 & & Não detectado \\
Fluxo $(\mathrm{mL} / \mathrm{min})$ & Não detectado & $0,17 \pm 0,01$ \\
0,3 & $15,30 \pm 0,02$ & $0,15 \pm 0,00$ \\
0,7 & $12,06 \pm 0,01$ & \\
\hline
\end{tabular}

Os resultados representam a média \pm desvio padrão de três ensaios. 
Tabela 23 - Resultados das variações de comprimento de onda, temperatura e fluxo para rutina no ensaio de robustez

\begin{tabular}{crc}
\hline Parâmetros avaliados & Tempo de Retenção $(\mathrm{min})$ & Área $\left(\mathrm{mAU}^{*} \mathrm{~min}\right)$ \\
\hline Comprimento de onda $(\mathrm{nm})$ & & \\
280 & $27,80 \pm 0,02$ & $0,42 \pm 0,00$ \\
330 & $27,80 \pm 0,03$ & $0,64 \pm 0,01$ \\
354 & $27,81 \pm 0,03$ & $0,92 \pm 0,01$ \\
Temperatura $\left({ }^{\circ} \mathrm{C}\right)$ & \\
25 & $27,81 \pm 0,03$ & $0,92 \pm 0,01$ \\
35 & $25,65 \pm 0,01$ & $1,03 \pm 0,04$ \\
45 & $23,59 \pm 0,01$ & $0,44 \pm 0,01$ \\
0,3 & & \\
0,5 & $34,75 \pm 0,02$ & $1,52 \pm 0,03$ \\
0,7 & $27,81 \pm 0,03$ & $0,92 \pm 0,01$ \\
Fluxo $(\mathrm{mL} / \mathrm{min})$ & $24,23 \pm 0,02$ & $0,72 \pm 0,01$ \\
\hline
\end{tabular}

Os resultados representam a média \pm desvio padrão de três ensaios.

Tabela 24 - Resultados das variações de comprimento de onda, temperatura e fluxo para isoquercitrina no ensaio de robustez

\begin{tabular}{ccc}
\hline Parâmetros avaliados & Tempo de Retenção (min) & Área (mAUmin) \\
\hline Comprimento de onda $(\mathrm{nm})$ & $29,86 \pm 0,02$ & $0,95 \pm 0,01$ \\
280 & $29,85 \pm 0,02$ & $1,44 \pm 0,02$ \\
330 & $29,85 \pm 0,02$ & $1,98 \pm 0,02$ \\
354 & & \\
Temperatura $\left({ }^{\circ} \mathrm{C}\right)$ & $29,85 \pm 0,02$ & $1,98 \pm 0,02$ \\
25 & $27,42 \pm 0,00$ & $1,74 \pm 0,04$ \\
35 & $25,09 \pm 0,01$ & $1,85 \pm 0,03$ \\
45 & & \\
Fluxo (mL/min) & $37,33 \pm 0,01$ & $2,78 \pm 0,03$ \\
0,3 & $29,85 \pm 0,02$ & $1,98 \pm 0,02$ \\
0,5 & $25,98 \pm 0,02$ & $1,40 \pm 0,03$ \\
0,7 & &
\end{tabular}

Os resultados representam a média \pm desvio padrão de três ensaios. 
Um método analítico inovador foi desenvolvido para a determinação e quantificação de três marcadores de atividade biológica conhecida - ácido clorogênico, rutina e isoquercitrina - no extrato padronizado das folhas de M. nigra. A padronização de extratos obtidos de espécies do gênero Morus foi relatada na literatura por Tallini (2014) na validação de metodologias analíticas para quantificação de quercetina e canferol em extratos hidrolisados de folhas de $M$. nigra (190).

Os resultados obtidos com a validação do método frente à de seletividade, linearidade, precisão, limites de detecção e quantificação, exatidão e robustez são importantes para o desenvolvimento de um fitoterápico, pois foi possível desenvolver uma alternativa aos métodos já existentes, que serve de ferramenta para o controle de qualidade de extratos de $M$. nigra. O método pode ser considerado validado por obter resultados confiáveis dentro dos limites aceitáveis segundo a Instrução Normativa N. ㄴ 4, de 18 de junho de 2014 (132) preconizada pela Anvisa, em que foi possível padronizar o extrato padronizado das folhas de M. nigra, quantificar seus compostos majoritários, de forma a garantir o controle da qualidade desta planta.

\subsubsection{Quantificação dos lotes de extrato padronizado de M. nigra}

A avaliação quantitativa química, que estima a quantidade dos constituintes majoritários, é um indício de qualidade que faz parte do processo de padronização (130). A RDC N. 26/2014 determina que seja avaliado o conteúdo dos marcadores tanto nas matérias-primas quanto no produto acabado (131).

O marcador é a substância ou classe de substâncias (ex: alcaloides, flavonoides, ácidos graxos, entre outros), utilizada como referência no controle da qualidade da matéria-prima vegetal e dos fitoterápicos, preferencialmente tendo correlação com o efeito terapêutico (132). No presente trabalho foram quantificados os marcadores ativos, aqueles que o constituinte tem relação com 0 efeito terapêutico.

Após validação da metodolodia e padronização do extrato padronizado das folhas de $M$. nigra para o lote $4 \mathrm{~A}$, amostras (2 mg/mL) dos cinco lotes foram 
analisadas em triplicata sob o método validado e quantificadas para ácido clorogênico, rutina e isoquercitrina (Figura 35).
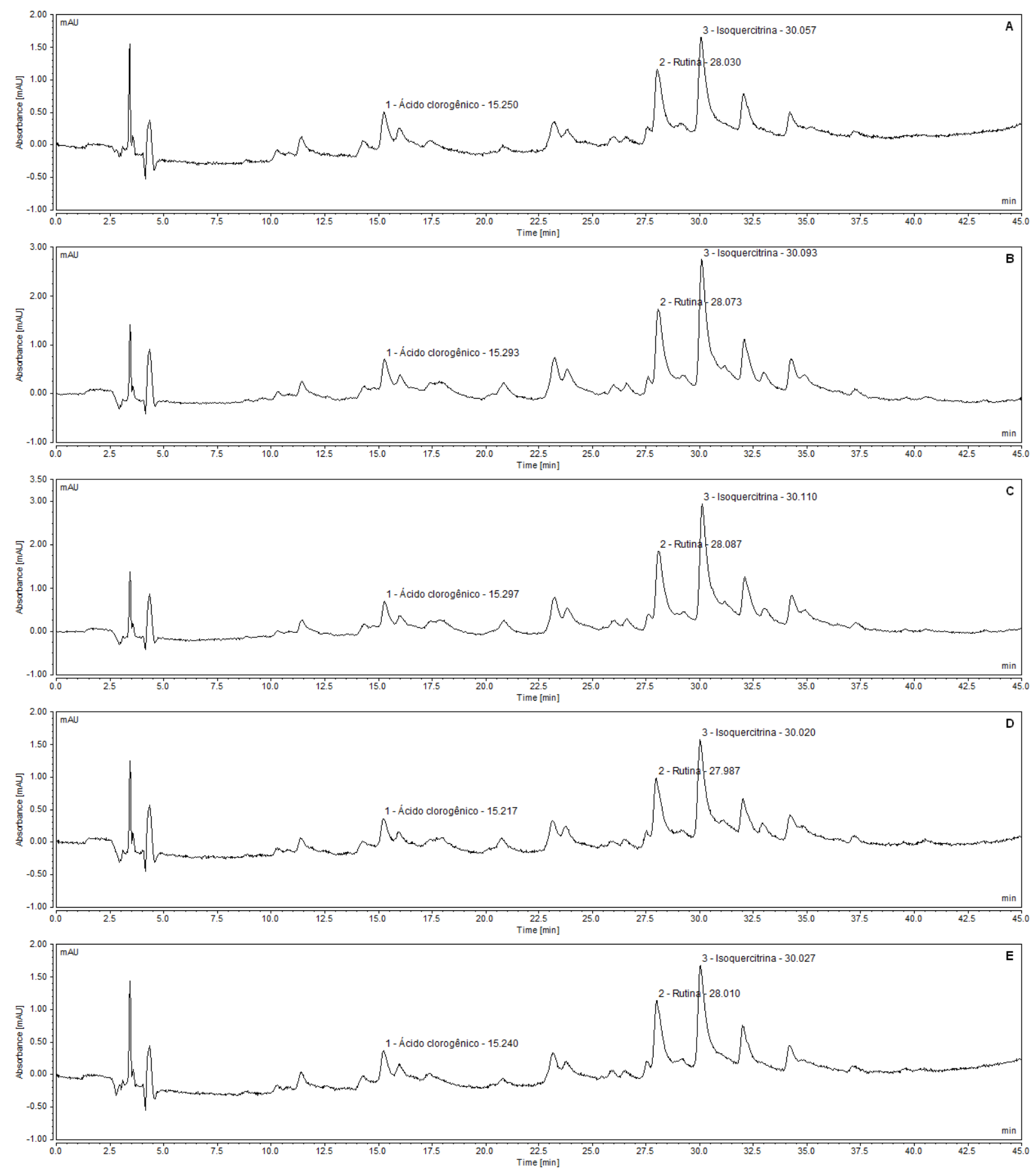

Figura 35 Cromatograma obtido por CLAE-DAD do extrato padronizado de $M$. nigra $2 \mathrm{mg} / \mathrm{mL}$. (A) lote $1 A$; (B) lote $2 A$; (C) lote $3 A$; (D) lote $4 A$; $(E)$ lote $5 A \lambda=354 \mathrm{~nm}$.

O lote que apresentou a maior concentração dos polifenóis estudados foi 0 lote 2 , seguido do lote 3 , lote 1 , lote 4 e lote 5 . A concentração de polifenóis presente 
no extrato está inversamente proporcional a concentração de extrato necessária para inibir $50 \%$ da atividade enzimática. Os lotes que apresentaram as maiores concentrações de polifenóis no extrato apresentaram os menores valores de $\mathrm{IC}_{50}$ para a inibição da enzima tirosinase, lote $2(5,14 \mu \mathrm{g} / \mathrm{mL} \pm 0,24)$ e lote $3(5,00 \mu \mathrm{g} / \mathrm{mL}$ $\pm 0,23)$. Tendo em vista que os compostos majoritários no extrato padronizado das folhas de $M$. nigra - ácido clorogênico, rutina e isoquercitrina - possuem atividade inibitória sobre a tirosinase $(9,169,170)$, é possível concluir que quanto maior a concentração de polifenóis no extrato, maior a atividade biológica sobre a tirosinase, e consequentemente, menor será o $I_{50}$. O desvio padrão relativo para as análises de cada lote realizadas em triplicata foi inferior a $15 \%$. Estes resultados são indicativos de boa precisão já que a literatura não admite valores de desvio padrão relativo superiores a $15 \%$ de acordo com o Guia de orientação para registro de Medicamento Fitoterápico e registro e notificação de Produto Tradicional Fitoterápico (132).

A quantificação dos marcadores em cada lote foi analisada estatísticamente por ANOVA com método Tukey $(p<0,05)$ (Figura 36). Houve diferença significativa no teor de ácido clorogênico do lote 2 em relação aos lotes 4 e 5, e diferença entre lotes 3 e 5 . Para rutina e isoquercitrina houve diferença significativa dos lotes 2 e 3 em relação aos lotes 1,4 e 5.

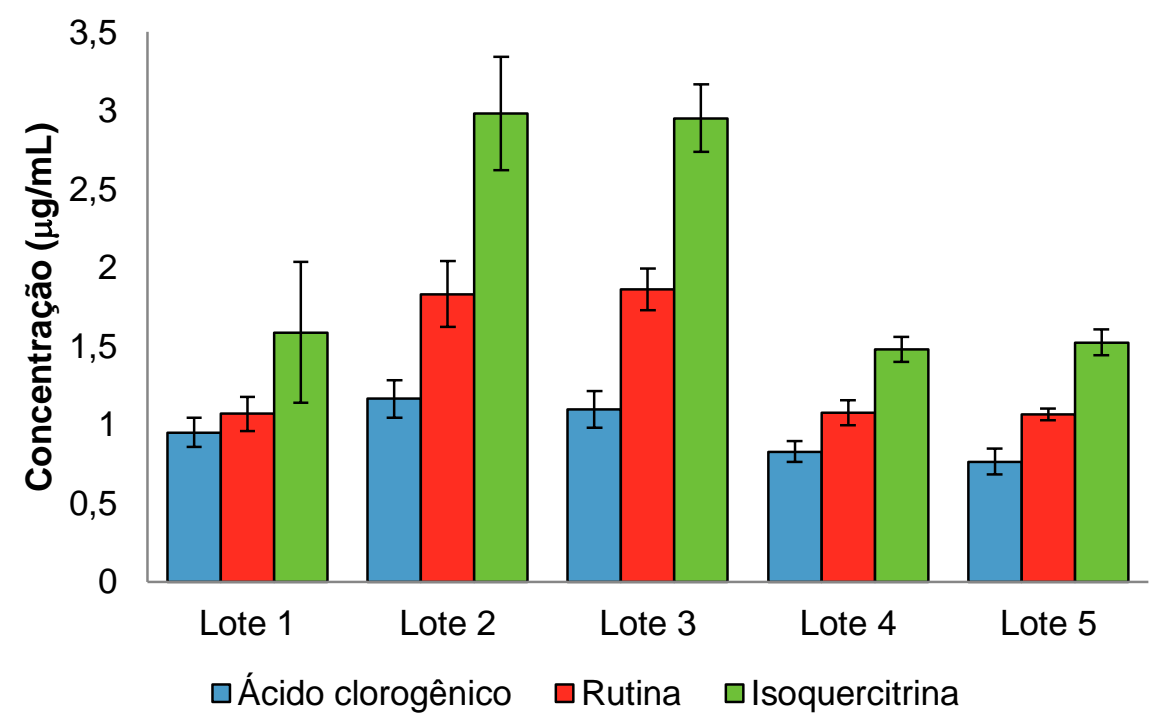

Figura 36 Quantificação de ácido clorogênico, rutina e isoquercitrina nos cinco lotes de extrato padronizado de M. nigra. 
Foi possível observar perfis cromatográficos semelhantes em todos os lotes, em que a isoquercitrina é o composto majoritário, seguindo de rutina. As proporções das concentrações dos marcadores presentes no extrato foram calculadas. A concentração de isoquercitrina no extrato padronizado de $M$. nigra é, em média, 2,34 vezes maior que o ácido clorogênico e, em média, 1,54 vezes maior que rutina em todos os lotes.

\subsection{CITOTOXICIDADE}

\subsubsection{Ensaio da citotoxicidade}

O reagente Cell Counting Kit-8 (Sigma-Aldrich, USA) utiliza o sal de tetrazólio solúvel em água (WST-8) [sal monossódio 2-(2- que produzmetoxi-4-nitrofenil)-3-(4nitrofenil)-5-(2,4-disulfofenil)-2H-tetrazólio] que produz um pigmento solúvel em água por bioredução na presença de um carreador de elétron. O WST-8 é reduzido por desidrogenases nas células gerando um produto de pigmento laranja (formazan), que é solúvel no meio de cultura celular. A quantidade de formazan gerado pela atividade das desidrogenases nas células é diretamente proporcional ao número de células vivas presente em cada poço da placa de 96 poços (191). Devido à intensa coloração do extrato padronizado de $M$. nigra, foi registrada uma elevada absorbância nos poços contendo a maior concentração estudada (2000 $\mu \mathrm{g} / \mathrm{mL}$ de extrato padronizado), sendo assim, os dados referentes a essa concentração foram desconsiderados e as porcentagens de viabilidade celular para as linhagens avaliadas e os valores de $\mathrm{IC}_{50}$ foram calculados a partir da concentração 1000 $\mu \mathrm{g} / \mathrm{mL}$ para as amostras.

O extrato padronizado de $M$. nigra foi citotóxico para as três linhagens celulares testadas a $1000 \mu \mathrm{g} / \mathrm{mL}$, porém não se mostraram citotóxicos nos valores aproximados de $\mathrm{IC}_{50}$ para inibição de tirosinase, como pode ser observado na Figura 37. 


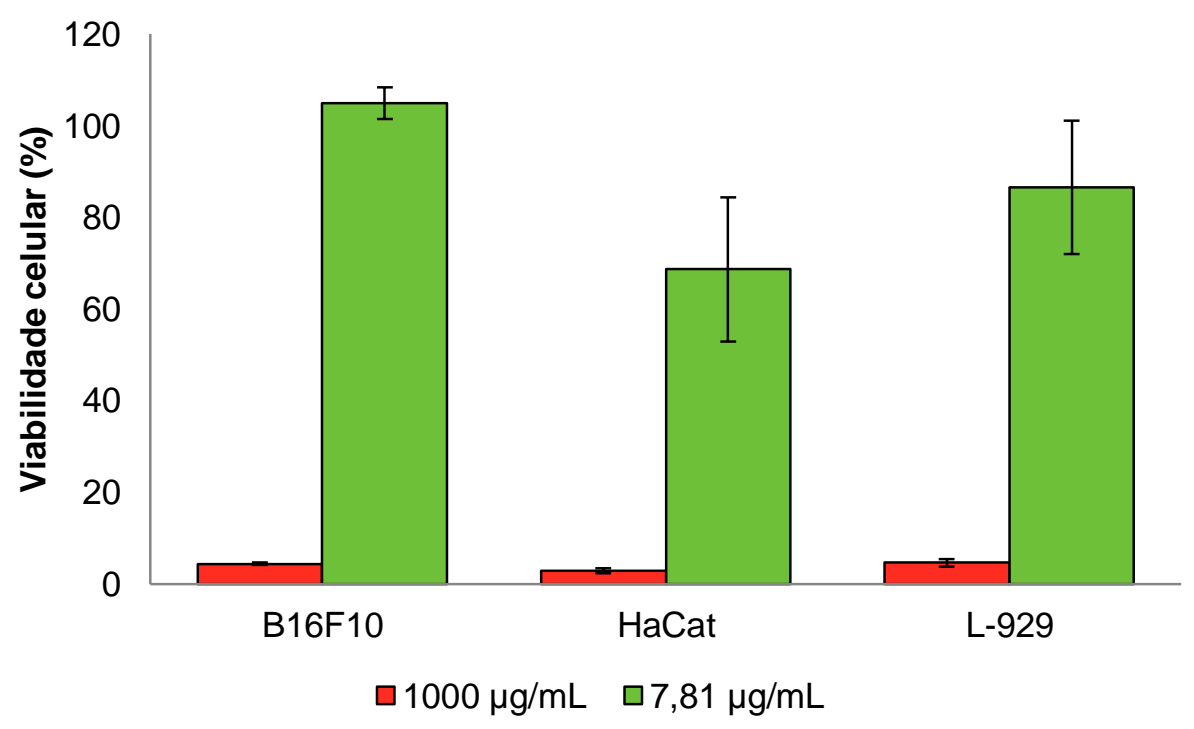

Figura 37 Viabilidade celular de melanoma (B16F10), queratinócito (HaCat) e fibloblasto (L-929) em $1000 \mu \mathrm{g} / \mathrm{mL}$ e $7,81 \mu \mathrm{g} / \mathrm{mL}$ do extrato padronizado de $M$. nigra.

As concentrações do extrato padronizado das folhas de $M$. nigra encontradas para inibir $50 \%$ do crescimento celular $\left(\mathrm{IC}_{50}\right)$ foram de $107,2 \mu \mathrm{g} / \mathrm{mL}$ para melanoma de murino; $324,2 \mu \mathrm{g} / \mathrm{mL}$ para queratinócito humano e $116,3 \mu \mathrm{g} / \mathrm{mL}$ para fibroblasto de camundongo, como demonstrado na Tabela 25.

Tabela 25 - Valores de $\mathrm{IC}_{50}$ para melanoma, queratinócito e fibroblasto frente ao método MTT para citotoxicidade

\begin{tabular}{ccc}
\hline Linhagem celular & Descrição & $\mathrm{IC}_{50}(\mu \mathrm{g} / \mathrm{mL})$ \\
\hline B16F10 & melanoma murino & 107,2 \\
HaCat & queratinócito humano & 324,2 \\
L-929 & fibroblasto camundongo & 116,3 \\
\hline
\end{tabular}

Para a triagem de efeitos antimelanogênicos, células B16F10 de melanoma murino foram amplamente utilizadas, provavelmente devido à relativa facilidade de cultura in vitro, e partilham a maioria dos mecanismos melanogênicos dos melanócitos humanos normais (68).

Os solventes álcool etílico $95 \%$ utilizado no processo extrativo, bem como o metanol utilizado na solubilização do extrato vegetal para a realização do presente ensaio, a uma concentração de $5,0 \%$ do volume total no poço $(200 \mu \mathrm{L})$, não 
demonstraram atividade citotóxica, assegurando a não-interferência nos resultados de citotoxicidade.

Não foi observada interação entre as diferentes concentrações de extrato testadas e WST-8, comprovando que o ensaio de tetrazólio MTT não levou a resultados falsos positivos.

A morte celular foi induzida através da adição de SDS 10,0 \% nos poços contendo as linhagens celulares.

Um estudo conduzido por Dória et al. (2015) avaliou a viabilidade celular do extrato hidroalcóolico de Remirea maritima Aubl. pelo método vermelho neutro frente às linhagens L-929 e B16F10, obtendo valores de $\mathrm{IC}_{50} 70,96 \mu \mathrm{g} / \mathrm{mL}$ e 108,30 $\mu \mathrm{g} / \mathrm{mL}$, respectivamente (192), similares aos achados no presente trabalho, entretanto, o extrato de $M$. nigra foi menos citotóxico para L-929 do que para o extrato de $R$. maritima. O efeito citotóxico dos extratos aquoso das folhas de Eugenia dysenterica e Pouteria torta foram avaliados nas linhagens HaCat e L-929 pelo método MTT nas concentrações de $500 \mu \mathrm{g} / \mathrm{mL}$ e nos valores de $I_{50}$ obtidos frente à inibição de tirosinase $(11,88 \mu \mathrm{g} / \mathrm{mL}$ e $30,01 \mu \mathrm{g} / \mathrm{mL}$, respectivamente), em que ambas as plantas são se mostraram citotóxicas nesta concentração, porém houve indução de toxicidade celular à $500 \mu \mathrm{g} / \mathrm{mL}$ (103).

O extrato padronizado de $M$. nigra se mostrou mais tóxico para a linhagem tumoral de melanoma de murino, o que sugere que o extrato possui atividade antitumoral como já descrito na literatura por Qadir et al. (2014) no extrato das folhas de M. nigra contra a linhagem de câncer cervical humano (HeLa) (25) e por Eo et al. (2014) no estudo da atividade anticâncer pelo extrato da casca da raiz de $M$. alba na linhagem de câncer coloretal humano (SW480) (193).

Segundo Li et al. (2014) o ácido clorogênico é provavelmente um substrato da melanina, mas seus produtos metabólicos podem suprimir a melanogênese em células de melanoma B16 por atividade de inibição da tirosinase (148). Além disso, em um estudo conduzido por Drewa et al. (1998), ratos foram injetados com células de melanoma B16 e tratados com solução de rutina, em que a administração de 10 mg de rutina inibiu a formação de melanina em aproximadamente 43 \% (194).

O extrato padronizado das folhas de $M$. nigra não se mostrou citotóxico nos valores de $\mathrm{IC}_{50}$ encontrados no ensaio de inibição da tirosinase. Nos valores de $\mathrm{IC}_{50}$ encontrados para citotoxicidade, o extrato de $M$. nigra possui atividade inibitória de 
tirosinase acima de $90 \%$, o que demonstra que este extrato é promissor como um agente despigmentante da pele por equilibrar baixa toxicidade e potente atividade inibitória da enzima de interesse. 


\section{CONCLUSÃO}

- Este trabalho obteve cinco lotes do extrato padronizado das folhas de $M$. nigra, os quais obtiveram reprodutibilidade quanto ao teor de sólidos totais, rendimento, teor de umidade e perfil cromatográfico em CCD;

- A inibição da enzima tirosinase foi avaliada, cuja porcentagem de inibição foi $>90 \%$ até $15,625 \mu \mathrm{g} / \mathrm{mL}$, similar ao ácido kójico;

- Determinar a concentração capaz de inibir $50 \%$ da atividade máxima $\left(\mathrm{IC}_{50}\right)$ da enzima de interesse pelo extrato testado;

- Os compostos fitoquímicos majoritários presentes no extrato padronizado foram identificados como isoquercitrina e rutina;

- Uma metodologia desenvolvida para a detecção de polifenóis presentes no extrato padronziado das folhas de $M$. nigra foi validada e o extrato foi padronizado para ácido clorogênico, rutina e isoquercitrina; e

- A citotoxicidade do extrato padronizado das folhas de M. nigra foi avaliada frente às linhagens de melanoma, queratinótico e fibroblasto em que o extrato não se mostrou citotóxico nas concentrações necessárias para inibir $50 \%$ da atividade da tirosinase.

- O extrato padronizado de $M$. nigra pode ser utilizado como um potencial agente despigmentante da pele nas indústrias farmacêutica e cosmética e como um agente antiescurecimento de frutas, legumes e bebidas na indústria de alimentos. 


\section{PERSPECTIVAS}

Com o propósito de dar continuidade ao trabalho, a otimização do processo extrativo e o fracionamento do extrato padronizado têm como finalidade isolar os compostos com atividade biológica e potencializar a atividade inibidora da tirosinase, que possivelmente alcançaria um $\mathrm{IC}_{50}$ inferior ao do controle positivo ácido kójico.

$O$ ensaio de quantificação de melanina intracelular e extracelular deve ser avaliado com a finalidade de verificar a produção deste pigmento nos melanomas pelo extrato de $M$. nigra em concentrações inibitórias da tirosinase que não citotóxicas, confirmando assim o seu efeito farmacológico.

Devido à baixa citotoxicidade do extrato frente às linhagens melanoma, queratinócito e fibroblasto, o próximo passo para o extrato padronziado de $M$. nigra se tornar um agente despigmentante é a incorporação em uma forma farmacêutica adequada que permita a liberação do extrato nos melanossomas, que contém tirosinase, encontrados na camada basal da epiderme. Posteriormente, a realização do teste de liberação visa quantificar a liberação do extrato no meio pela formulação definida, seguido do teste de permeação, que tem como finalidade avaliar até que camada da pele o extrato atingiu e, por fim, avaliar a estabilidade do extrato padronizado de $M$. nigra. 


\section{REFERÊNCIAS BIBLIOGRÁFICAS}

1. Solano F, Briganti S, Picardo M, Ghanem G. Hypopigmenting agents: an updated review on biological, chemical and clinical aspects. Pigment Cell Res. 2006;19(6):550-71.

2. Momtaz S, Lall N, Basson A. Inhibitory activities of mushroom tyrosine and DOPA oxidation by plant extracts. South African Journal of Botany. 2008;74:577-82.

3. Zhu W, Gao J. The use of botanical extracts as topical skin-lightening agents for the improvement of skin pigmentation disorders. J Investig Dermatol Symp Proc. 2008;13(1):20-4.

4. Patel DK, Patel K, Duraiswamy B, Dhanabal SP. Phytochemical analysis and standardization of Strychnos nux-vomica extract through HPTLC techniques. Asian Pac J Trop Dis. 2012:S56-S60.

5. OMS. WHO Traditional Medicine Strategy 2014-2023 2013. [Disponível em: http://apps.who.int/iris/bitstream/10665/92455/1/9789241506090 eng.pdf?ua=1].

6. Özgen M, Serçe S, Kaya C. Phytochemical and antioxidant properties of anthocyanin-rich Morus nigra and Morus rubra fruits. Sci Hortic (Amsterdam). 2009;119(3):275-9.

7. Park KT, Kim JK, Hwang D, Yoo Y, Lim YH. Inhibitory effect of mulberroside A and its derivatives on melanogenesis induced by ultraviolet $B$ irradiation. Food Chem Toxicol. 2011;49(12):3038-45.

8. Lee SH, Choi SY, Kim H, Hwang JS, Lee BG, Gao JJ, et al. Mulberroside F isolated from the leaves of Morus alba inhibits melanin biosynthesis. Biol Pharm Bull. 2002;25(8):1045-8.

9. Chang LW, Juang LJ, Wang BS, Wang MY, Tai HM, Hung WJ, et al. Antioxidant and antityrosinase activity of mulberry (Morus alba L.) twigs and root bark. Food Chem Toxicol. 2011;49(4):785-90.

10. Zheng ZP, Tan HY, Wang M. Tyrosinase inhibition constituents from the roots of Morus australis. Fitoterapia. 2012;83(6):1008-13.

11. Takahashi M, Takara K, Toyozato T, Wada K. A novel bioactive chalcone of Morus australis inhibits tyrosinase activity and melanin biosynthesis in B16 melanoma cells. J Oleo Sci. 2012;61(10):585-92. 
12. Masuda T, Yamashita D, Takeda Y, Yonemori S. Screening for Tyrosinase Inhibitors among Extracts of Seashore Plants and Identification of Potent Inhibitors from Gardenia subelliptica. Biosci Biotechnol Biochem. 2005;69(1):197-201.

13. Ryu YB, Ha TJ, Curtis-Long MJ, Ryu HW, Gal SW, Park KH. Inhibitory effects on mushroom tyrosinase by flavones from the stem barks of Morus Ihou (S.) Koidz. J Enzyme Inhib Med Chem. 2008;23(6):922-30.

14. Jeong SH, Ryu YB, Curtis-Long MJ, Ryu HW, Baek YS, Kang JE, et al. Tyrosinase inhibitory polyphenols from roots of Morus Ihou. J Agric Food Chem. 2009;57(4):1195-203.

15. Wang S, Liu XM, Zhang J, Zhang YQ. An efficient preparation of mulberroside a from the branch bark of mulberry and its effect on the inhibition of tyrosinase activity. PLoS One. 2014;9(10):e109396.

16. Hu X, Wang M, Yan GR, Yu MH, Wang HY, Hou AJ. 2-Arylbenzofuran and tyrosinase inhibitory constituents of Morus notabilis. J Asian Nat Prod Res. 2012;14(12):1103-8.

17. Hu X, Wu JW, Wang M, Yu MH, Zhao QS, Wang HY, et al. 2-Arylbenzofuran, flavonoid, and tyrosinase inhibitory constituents of Morus yunnanensis. J Nat Prod. 2012;75(1):82-7.

18. Oliveira ACB, Oliveira AP, Guimarães AL, Oliveira RA, Silva FS, Reirs SAGB, et al. Avaliação toxicológica pré-clínica do chá das folhas de Morus nigra L. (Moraceae). Rev Bras PI Med. 2013;15(2):244-9.

19. Arfan M, Khan R, Rybarczyk A, Amarowicz R. Antioxidant activity of mulberry fruit extracts. Int J Mol Sci. 2012;13(2):2472-80.

20. Ercisli S, Tosun M, Duralija B, Voca S, Sengul M, Turan M. Phytochemical Content of Some Black (Morus nigra L.) and Purple (Morus rubra L.) Mulberry Genotypes. Food Technol Biotechnol. 2010;48(1):102-6.

21. Hassimotto NM, Genovese MI, Lajolo FM. Antioxidant activity of dietary fruits, vegetables, and commercial frozen fruit pulps. J Agric Food Chem. 2005;53(8):292835.

22. Imran $\mathrm{M}$, Khan $\mathrm{H}$, Shah $\mathrm{M}$, Khan $\mathrm{R}$, Khan F. Chemical composition and antioxidant activity of certain Morus species. J Zhejiang Univ Sci B. 2010;11(12):97380. 
23. Mazimba O, Majinda RRT, Motlhanka D. Antioxidant and antibacterial constituents from Morus nigra. African Journal of Pharmacy and Pharmacology. $2011 ; 5(6): 751-4$.

24. Naderi GA, Asgary S, Sarraf-Zadegan N, Oroojy H, Afshin-Nia F. Antioxidant activity of three extracts of Morus nigra. Phytother Res. 2004;18(5):365-9.

25. Qadir MI, Ali M, Ibrahim Z. Anticancer activity of Morus nigra leaves extract. Bangladesh J Pharmacol. 2014;9:496-7.

26. Mallhi TH, Qadir MI, Khan YH, Ali M. Hepatoprotective activity of aqueous methanolic extract of Morus nigra against paracetamol-induced hepatotoxicity in mice. Bangladesh Journal of Pharmacol. 2014;9:60-6.

27. Hanif F, Singh DK. Molluscicidal activity of Morus nigra against the freshwater snail Lymnaea acuminata. J biol earth sci. 2012;2(2):B54-B62.

28. Ercisli S, Orhan E. Chemical composition of white (Morus alba), red (Morus rubra) and black (Morus nigra) mulberry fruits. Food Chem. 2007;103:1380-4.

29. Zhang X, Hu X, Hou A, Wang H. Inhibitory effect of 2,4,2',4'-tetrahydroxy-3-(3methyl-2-butenyl)-chalcone on tyrosinase activity and melanin biosynthesis. Biol Pharm Bull. 2009;32(1):86-90.

30. Zheng ZP, Cheng KW, Zhu Q, Wang XC, Lin ZX, Wang M. Tyrosinase inhibitory constituents from the roots of Morus nigra: a structure-activity relationship study. J Agric Food Chem. 2010;58(9):5368-73.

31. Kim K. Effect of ginseng and ginsenosides on melanogenesis and their mechanism of action. J Ginseng Res. 2015;39(1):1-6.

32. Sánchez-Ferrer A, Rodríguez-López JN, García-Cánovas F, García-Carmona F. Tyrosinase: a comprehensive review of its mechanism. Biochim Biophys Acta. $1995 ; 1247(1): 1-11$.

33. Speeckaert R, Van Gele M, Speeckaert MM, Lambert J, van Geel N. The biology of hyperpigmentation syndromes. Pigment Cell Melanoma Res. 2014;27(4):512-24.

34. Wakamatsu K, Ito S. Advanced chemical methods in melanin determination. Pigment Cell Res. 2002;15(3):174-83.

35. Kim JH, Lee SM, Myung CH, Lee KR, Hyun SM, Lee JE, et al. Melanogenesis inhibition of $\beta$-lapachone, a natural product from Tabebuia avellanedae, with effective in vivo lightening potency. Arch Dermatol Res. 2015;307(3):229-38. 
36. Kim YJ, Uyama H. Tyrosinase inhibitors from natural and synthetic sources: structure, inhibition mechanism and perspective for the future. Cell Mol Life Sci. 2005;62(15):1707-23.

37. Rose PT. Pigmentary disorders. Med Clin North Am. 2009;93(6):1225-39.

38. Nole G, Johnson AW. An analysis of cumulative lifetime solar ultraviolet radiation exposure and the benefits of daily sun protection. Dermatol Ther. 2004;17 Suppl 1:57-62.

39. Zhu PY, Yin WH, Wang MR, Dang YY, Ye XY. Andrographolide suppresses

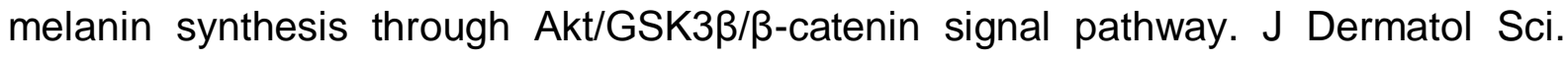
2015.

40. Lee AY, Noh M. The regulation of epidermal melanogenesis via cAMP and/or PKC signaling pathways: insights for the development of hypopigmenting agents. Arch Pharm Res. 2013;36(7):792-801.

41. Costin GE, Hearing VJ. Human skin pigmentation: melanocytes modulate skin color in response to stress. FASEB J. 2007;21(4):976-94.

42. Pandya AG, Guevara IL. Disorders of hyperpigmentation. Dermatol Clin. 2000;18(1):91-8, ix.

43. Ikino JK, Nunes DH, Silva VP, Fröde TS, Sens MM. Melasma and assessment of the quality of life in Brazilian women. An Bras Dermatol. 2015;90(2):196-200.

44. Kolbe L, Mann T, Gerwat W, Batzer J, Ahlheit S, Scherner C, et al. 4-nbutylresorcinol, a highly effective tyrosinase inhibitor for the topical treatment of hyperpigmentation. J Eur Acad Dermatol Venereol. 2013;27 Suppl 1:19-23.

45. Gilchrest BA. Molecular aspects of tanning. J Invest Dermatol. 2011;131(E1):E14-7.

46. Briganti S, Camera E, Picardo M. Chemical and instrumental approaches to treat hyperpigmentation. Pigment Cell Res. 2003;16(2):101-10.

47. Kwon BS, Haq AK, Pomerantz SH, Halaban R. Isolation and sequence of a cDNA clone for human tyrosinase that maps at the mouse c-albino locus. Proc Natl Acad Sci U S A. 1987;84(21):7473-7.

48. Lerner AB, Fitzpatrick TB. Mammalian tyrosinase; preparation and properties. J Biol Chem. 1949;178(1):185-95.

49. Lerner AB, Fitzpatrick TB, Calkins E, Summerson WH. Mammalian tyrosinase; action on substances structurally related to tyrosine. J Biol Chem. 1951;191(2):799806. 
50. Betancourt AM, Bernan V, Herber W, Katz E. Analysis of tyrosinase synthesis in Streptomyces antibioticus. Journal of General Microbiology. 1992;138:787-94.

51. Kohashi PY, Kumagai T, Matoba Y, Yamamoto A, Maruyama M, Sugiyama M. An efficient method for the overexpression and purification of active tyrosinase from Streptomyces castaneoglobisporus. Protein Expr Purif. 2004;34(2):202-7.

52. Dolashki A, Gushterova A, Voelter W, Tchorbanov B. Purification and characterization of tyrosinases from Streptomyces albus. Z Naturforsch C. 2009;64(9-10):724-32.

53. Liu N, Zhang T, Wang YJ, Huang YP, Ou JH, Shen P. A heat inducible tyrosinase with distinct properties from Bacillus thuringiensis. Lett Appl Microbiol. $2004 ; 39(5): 407-12$.

54. Shuster V, Fishman A. Isolation, cloning and characterization of a tyrosinase with improved activity in organic solvents from Bacillus megaterium. J Mol Microbiol Biotechnol. 2009;17(4):188-200.

55. Wan X, Chai B, Liao Y, Su Y, Ye T, Shen P, et al. Molecular and biochemical characterization of a distinct tyrosinase involved in melanin production from Aeromonas media. Appl Microbiol Biotechnol. 2009;82(2):261-9.

56. Kong KH, Hong MP, Choi SS, Kim YT, Cho SH. Purification and characterization of a highly stable tyrosinase from Thermomicrobium roseum. Biotechnol Appl Biochem. 2000;31 ( Pt 2):113-8.

57. Fairhead M, Thöny-Meyer L. Role of the C-terminal extension in a bacterial tyrosinase. FEBS J. 2010;277(9):2083-95.

58. Halaouli S, Asther M, Sigoillot JC, Hamdi M, Lomascolo A. Fungal tyrosinases: new prospects in molecular characteristics, bioengineering and biotechnological applications. J Appl Microbiol. 2006;100(2):219-32.

59. Goldfeder M, Kanteev M, Isaschar-Ovdat S, Adir N, Fishman A. Determination of tyrosinase substrate-binding modes reveals mechanistic differences between type3 copper proteins. Nat Commun. 2014;5:4505.

60. Mayer AM. Polyphenol oxidases in plants and fungi: going places? A review. Phytochemistry. 2006;67(21):2318-31.

61. Gerdemann C, Eicken C, Krebs B. The crystal structure of catechol oxidase: new insight into the function of type-3 copper proteins. Acc Chem Res. 2002;35(3):183-91. 
62. Lerch K, Huber M, Schneider H-J, Drexel R, Linzen B. Different Origins of Metal Binding Sites in Binuclear Copper Proteins, Tyrosinase and Hemocyanin. J Inorg Biochem. 1986;26(3):213-7.

63. Lerner AB, Fitzpatrick TB, Calkins E, Summerson WH. Mammalian tyrosinase; the relationship of copper to enzymatic activity. J Biol Chem. 1950;187(2):793-802.

64. Durán N, Rosa MA, D’Annibale A, Gianfreda L. Applications of laccases and tyrosinases (phenoloxidases) immobilized on different supports: a review. Enzyme Microb Technol. 2002;31(7):907-31.

65. Gupta AK, Gover MD, Nouri K, Taylor S. The treatment of melasma: a review of clinical trials. J Am Acad Dermatol. 2006;55(6):1048-65.

66. Hearing VJ, Tsukamoto K. Enzymatic control of pigmentation in mammals. FASEB J. 1991;5(14):2902-9.

67. Chang TS. An updated review of tyrosinase inhibitors. Int $\mathrm{J}$ Mol Sci. 2009;10(6):2440-75.

68. Chang T. Natural Melanogenesis Inhibitors Acting Through the DownRegulation of Tyrosinase Activity. Materials. 2012;5:1661-85.

69. Cooksey CJ, Garratt PJ, Land EJ, Pavel S, Ramsden CA, Riley PA, et al. Evidence of the indirect formation of the catecholic intermediate substrate responsible for the autoactivation kinetics of tyrosinase. $J$ Biol Chem. 1997;272(42):26226-35.

70. Schallreuter KU, Kothari S, Chavan B, Spencer JD. Regulation of melanogenesis--controversies and new concepts. Exp Dermatol. 2008;17(5):395404.

71. Simon JD, Goldsmith MR, Hong L, Kempf VR, McGuckin LE, Ye T, et al. Spectroscopy and photoreactivity of trichochromes: molecular components of pheomelanins. Photochem Photobiol. 2006;82(1):318-23.

72. Jung E, Hwang W, Kim S, Kim YS, Lee J, Park D. Depigmenting action of platycodin $D$ depends on the cAMP/Rho-dependent signalling pathway. Exp Dermatol. $2011 ; 20(12): 986-91$.

73. Jiménez M, Chazarra S, Escribano J, Cabanes J, García-Carmona F. Competitive inhibition of mushroom tyrosinase by 4 -substituted benzaldehydes. $J$ Agric Food Chem. 2001;49(8):4060-3. 
74. Rigal D, Cerny M, Richard-Forget F, Varoquaux P. Inhibition of endive (Cichorium endivia L.) polyphenoloxidase by a Carica papaya latex preparation. International Journal of Food Science and Technology. 2001;36:677-84.

75. Son SM, Moon KD, Lee CY. Rhubarb Juice as a Natural Antibrowning Agent. Journal of Food Science. 2000;65(8):1288-9.

76. García-Gavín J, González-Vilas D, Fernández-Redondo V, Toribio J. Pigmented contact dermatitis due to kojic acid. A paradoxical side effect of a skin lightener. Contact Dermatitis. 2010;62(1):63-4.

77. Fuyuno I. Spotlight turns on cosmetics for Asian skin. Nature. 2004;432(7020):938.

78. Curto EV, Kwong C, Hermersdörfer H, Glatt H, Santis C, Virador V, et al. Inhibitors of mammalian melanocyte tyrosinase: in vitro comparisons of alkyl esters of gentisic acid with other putative inhibitors. Biochem Pharmacol. 1999;57(6):66372.

79. Ribas J, Schettini APM, Cavalcante MdSM. Ocronose exógena induzida por hidroquinona: relato de quatro casos. Anais Brasileiros de Dermatologia. 2010;85.

80. Gandhi V, Verma P, Naik G. Exogenous ochronosis After Prolonged Use of Topical Hydroquinone (2\%) in a 50-Year-Old Indian Female. Indian J Dermatol. 2012;57(5):394-5.

81. Zheng Z-P, Cheng K-W, Chao J, Wu J, Wang M. Tyrosinase inhibitors from paper mulberry (Broussonetia papyrifera). Food Chem. 2008;106:529-35.

82. Chen $\mathrm{QX}$, Huang $\mathrm{H}$, Kubo I. Inactivation kinetics of mushroom tyrosinase by cetylpyridinium chloride. J Protein Chem. 2003;22(5):481-7.

83. Qiu L, Chen QX, Wang Q, Huang H, Song KK. Irreversibly inhibitory kinetics of 3,5-dihydroxyphenyl decanoate on mushroom (Agaricus bisporus) tyrosinase. Bioorg Med Chem. 2005;13(22):6206-11.

84. Liu SH, Pan IH, Chu IM. Inhibitory effect of p-hydroxybenzyl alcohol on tyrosinase activity and melanogenesis. Biol Pharm Bull. 2007;30(6):1135-9.

85. Chang TS. An updated review of tyrosinase inhibitors. Int $\mathrm{J}$ Mol Sci. 2009;10(6):2440-75.

86. Burnett CL, Bergfeld WF, Belsito DV, Hill RA, Klaassen CD, Liebler DC, et al. Final report of the safety assessment of Kojic acid as used in cosmetics. Int $\mathrm{J}$ Toxicol. 2010;29(6 Suppl):244S-73. 
87. Chen Q-X, Song K-K, Qiu L, Liu X-D, Huang H, Guo H-Y. Inhibitory effects on mushroom tyrosinase by p-alkoxybenzoic acids. Food Chem. 2005;91:269-74.

88. Cho SJ, Roh JS, Sun WS, Kim SH, Park KD. N-Benzylbenzamides: a new class of potent tyrosinase inhibitors. Bioorg Med Chem Lett. 2006;16(10):2682-4.

89. Huang X-H, Chen Q-X, Wang Q, Song K-K, Wang J, Sha L, et al. Inhibition of the activity of mushroom tyrosinase by alkylbenzoic acids. Food Chem. 2006;94:1-6. 90. Jun N, Hong G, Jun K. Synthesis and evaluation of 2',4',6'-trihydroxychalcones as a new class of tyrosinase inhibitors. Bioorg Med Chem. 2007;15:2396-402.

91. Chen C-Y, Kuo P-L, Chen Y-H, Huang J-C, Ho M-L, Lin R-J, et al. Tyrosinase inhibition, free radical scavenging, antimicroorganism and anticancer proliferation activities of Sapindus mukorossi extracts J Taiwan Inst Chem Eng. 2010;41:129-35.

92. Iwai K, Kishimoto N, Kakino Y, Mochida K, Fujita T. In vitro antioxidative effects and tyrosinase inhibitory activities of seven hydroxycinnamoyl derivatives in green coffee beans. J Agric Food Chem. 2004;52(15):4893-8.

93. Karioti A, Protopappa A, Megoulas N, Skaltsa H. Identification of tyrosinase inhibitors from Marrubium velutinum and Marrubium cylleneum. Bioorg Med Chem. 2007;15(7):2708-14.

94. Khan SB, Azhar-Ul-Haq, Afza N, Malik A, Khan MT, Shah MR, et al. Tyrosinase-inhibitory long-chain esters from Amberboa ramosa. Chem Pharm Bull (Tokyo). 2005;53(1):86-9.

95. Kubo I, Kinst-Hori I. Tyrosinase Inhibitors from Anise Oil. J Agric Food Chem. 1998;46:1268-71.

96. Kubo I, Kinst-Hori I. Tyrosinase Inhibitors from Cumin. J Agric Food Chem. 1998;46:5338-41.

97. Kubo I, Kinst-Hori I, Chaudhuri SK, Kubo Y, Sánchez Y, Ogura T. Flavonols from Heterotheca inuloides: Tyrosinase Inhibitory Activity and Structural Criteria. Bioorg Med Chem. 2000;8(7):1749-55.

98. Kubo I, Kinst-Hori I. Flavonols from Saffron Flower: Tyrosinase Inhibitory Activity and Inhibition Mechanism J Agric Food Chem. 1999;47:4121-5.

99. Lai J-S, Lin C-C, Chiang T-M. Tyrosinase Inhibitory Activity and Thermostability of the Flavonoid Complex from Sophora japonica $L$ (Fabaceae) Trop J Pharm Res. 2014;13(2):243-7.

100. Lim TY, Lim YY, Yule CM. Evaluation of antioxidant, antibacterial and antityrosinase activities of four Macaranga species Food Chem. 2009;114:594-9. 
101. Maisuthisakul P, Gordon $\mathrm{MH}$. Antioxidant and tyrosinase inhibitory activity of mango seed kernel by product. Food Chem. 2009;117(2):332-41.

102. Yagi A, Kanbara T, Morinobu N. Inhibition of mushroom-tyrosinase by aloe extract. Planta Med. 1987;53(6):515-7.

103. Souza PM, Elias ST, Simeoni LA, de Paula JE, Gomes SM, Guerra EN, et al. Plants from Brazilian Cerrado with potent tyrosinase inhibitory activity. PLoS One. 2012;7(11):e48589.

104. Baurin N, Arnoult E, Scior T, Do QT, Bernard P. Preliminary screening of some tropical plants for anti-tyrosinase activity. J Ethnopharmacol. 2002;82(2-3):1558.

105. Ya W, Chun-Meng Z, Tao G, Yi-Lin Z, Ping Z. Preliminary screening of 44 plant extracts for anti-tyrosinase and antioxidant activities. Pak J Pharm Sci. $2015 ; 28(5): 1737-44$.

106. Watson L, Dallwitz MJ. The families of flowering plants: descriptions, illustrations, identification, and information retrieval 1992 [Disponível em: deltaintkey.com].

107. Awasthi AK, Nagaraja GM, Naik GV, Kanginakudru S, Thangavelu K, Nagaraju J. Genetic diversity and relationships in mulberry (genus Morus) as revealed by RAPD and ISSR marker assays. BMC Genet. 2004;5:1-9.

108. Souza VC, Lorenzi H. Botânica Sistemática: Guia ilustrado para identificação das famílias de Fanerógamas nativas e exóticas no Brasil, baseado em APG II. 2 ed. Nova Odessa - SP: Instituto Plantarum de Estudos da Flora; 2008. 704 p.

109. Fuko Okamoto F, Furlaneto FdPB, Martins AN. Amora preta: quem é quem? [Disponível em: http://www.aptaregional.sp.gov.br]. Pesquisa \& Tecnologia. 2013;10(2).

110. Bediaga B, Drummond RP. Cronologia Jardim Botânico do Rio de Janeiro. Instituto de Pesquisas Jardim Botânico do Rio de Janeiro. [Disponível em: http://www.jbri.gov.br/sites/all/themes/corporateclean/content/publicacoes/cronologia. pdf\%5D]. 2007. p. 1-34.

111. Busch APB. Análise da conjuntura agropecuária safra 2010/2011: sericicultura. Secretaria da Agricultura e do Abastecimento. Departamento de Economia Rural. [Disponível em: http://www.pr.gov.br/seab\%5D]. 2010. p. 1-18.

112. Almeida JE, Fonseca TC. Mulberry For Animal Production. Mulberry germplasm and cultivation in Brazil: FAO Animal Production And Health Paper; 2000. 
113. Butt MS, Nazir A, Sultan MT, Schroen K. Morus alba L. nature's functional tonic. Trends Food Sci Technol. 2008;19:505-12.

114. Singh R, Bagachi A, Semwal A, SatinderKaur, bharadwaj A. Traditional uses, phytochemistry and pharmacology of Morus alba Linn.: A review. Journal of Medicinal Plants Research. 2013;7(9):461-9.

115. Kurniati NF, Suryani GP, Sigit Jl. Vasodilator Effect of Ethanolic Extract of Mulberry Leaves (Morus alba L.) in Rat and Rabbit. Procedia Chemistry. $2014 ; 13: 142-6$.

116. Shin NH, Ryu SY, Choi EJ, Kang SH, Chang IM, Min KR, et al. Oxyresveratrol as the potent inhibitor on dopa oxidase activity of mushroom tyrosinase. Biochem Biophys Res Commun. 1998;243(3):801-3.

117. Kim M, Park J, Song K, Kim HG, Koh JS, Boo YC. Screening of plant extracts for human tyrosinase inhibiting effects. Int J Cosmet Sci. 2012;34(2):202-8.

118. Jiang $\mathrm{Y}$, Nie WJ. Chemical properties in fruits of mulberry species from the Xinjiang province of China. Food Chem. 2015;174:460-6.

119. Golçalves EG, Lorenzi H. Morfologia Vegetal: Organografia e Dicionário llustrado de Morfologia das Plantas Vasculares. São Paulo: Instituto Plantarum de Estudos da Flora; 2007. 416 p.

120. Padilha MM, Moreira LQ, Morais FF, Araújo TH, Alves-da-Silva G. Estudo farmacobotânico das folhas de amoreira-preta, Morus nigra L., Moraceae. Rev Bras Farmacogn. 2010;20(4):621-6.

121. Song W, Wang HJ, Bucheli P, Zhang PF, Wei DZ, Lu YH. Phytochemical profiles of different mulberry (Morus sp.) species from China. J Agric Food Chem. 2009;57(19):9133-40.

122. Zamoner LOB. Síntese de iminoaçúcares modificados e avaliação da atividade biológica. Ribeirão Preto: Universidade de São Paulo; 2012.

123. Wang L, Wang HQ, Chen RY. [Studies on chemical constituents from bark of Morus nigra]. Zhongguo Zhong Yao Za Zhi. 2007;32(23):2497-9.

124. Silva RAD. Pharmacopeia dos Estados Unidos do Brasil. 1 ed1926. 1065 p.

125. Saúde Md. MS elabora Relação de Plantas Medicinais de Interesse ao SUS: Portal da Saúde; 2009 [Disponível em: http://portalsaude.saude.gov.br/index.php/cidadao/principal/agencia-saude/noticiasanteriores-agencia-saude/3487-ms-elabora-relacao-de-plantas-medicinais-deinteresse-ao-sus]. 
126. Eleazu CO, Eleazu KC, E. A, Chukwuma SC. Comparative study of the phytochemical composition of the leaves of five Nigerian medicinal plants. Journal of Biotechnology and Pharmaceutical Research. 2012;3(2):42-6.

127. Ravi A, Mallika A, Sama V, Begum AS, Khan RS, Reddy BM. Antiproliferative activity and standardization of Tecomella undulata bark extract on K562 cells. J Ethnopharmacol. 2011;137(3):1353-9.

128. Palav Y, D'mello PM. Standardization of selected Indian medicinal herbal raw materials containing polyphenols as major phytoconstituents. Indian J Pharm Sci. 2006;68(4):506-9.

129. Garg V, Dhar VJ, Sharma A, Dutt R. Facts about standardization of herbal medicine: a review. Zhong Xi Yi Jie He Xue Bao. 2012;10(10):1077-83.

130. Kunle OF, Egharevba HO, Ahmadu PO. Standardization of herbal medicines A review. Int J Biodivers Conserv. 2012;4(3):101-12.

131. Agência Nacional de Vigilância Sanitária (Brasil). Resolução RDC N. ${ }^{\circ} 26$, de 13 de maio de 2014. Registro de Medicamentos Fitoterápicos e o registro e a notificação de Produtos Tradicionais Fitoterápicos.

132. Agência Nacional de Vigilância Sanitária (Brasil). Instrução Normativa N ${ }^{\circ} 4$, de 18 de junho de 2014. Guia de orientação para registro de Medicamento Fitoterápico e registro e notificação de Produto Tradicional Fitoterápico. Diário Oficial da União 2 jun 2014.

133. Agência Nacional de Vigilância Sanitária (Brasil). Resolução - RE nº 899, de 29 de maio de 2003. Guia para Validação de Métodos Analíticos e Bioanalíticos. Diário Oficial da União 2 jun 2003.

134. INMET. Instituto Nacional de Metereologia 2014 [Disponível em: http://www.inmet.gov.br/portal/index.php?r=bdmep/bdmep].

135. Anvisa. Farmacopeia Brasileira. 5 $5^{\mathbf{a}}$ ed. Brasília, Brasil: Agência Nacional de Vigilância Sanitária; 2010. 546 p.

136. Anvisa. Formulário de Fitoterápicos da Farmacopeia Brasileira. 1 ed. Brasília, Brasil: Agência Nacional de Vigilância Sanitária; 2011.

137. Wagner H, Bladt S. Plant Drug Analysis A Thin-Layer Chromatography Atlas. 2 ed: Springer; 1996.

138. Souza PM. Atividade de Inibição Enzimática por Espécies Vegetais do Bioma Cerrado. Brasília: Universidade de Brasília; 2011. 
139. Khatib S, Nerya O, Musa R, Shmuel M, Tamir S, Vaya J. Chalcones as potent tyrosinase inhibitors: the importance of a 2,4-substituted resorcinol moiety. Bioorg Med Chem. 2005;13(2):433-41.

140. Leite CFM, Leite BHM, Barros IMdC, Gomes SM, Fagg CW, Simeoni LA, et al. Determination of rutin in Erythroxylum suberosum extract by liquid chromatography: applicability in standardization of herbs and stability studies. Boletín Latinoamericano y del Caribe de Plantas Medicinales y Aromáticas. 2014;13(2):135-43.

141. ICH. Guidance for Industry. Q2B Validation of Analytical Procedures: Methodology. In: Services USDoHaH, Administration FaD, (CDER) CfDEaR, (CBER) CfBEaR, editors. 1996.

142. Mosmann T. Rapid colorimetric assay for cellular growth and survival: application to proliferation and cytotoxicity assays. J Immunol Methods. 1983;65(12):55-63.

143. Bruggisser R, von Daeniken K, Jundt G, Schaffner W, Tullberg-Reinert $H$. Interference of plant extracts, phytoestrogens and antioxidants with the MTT tetrazolium assay. Planta Med. 2002;68(5):445-8.

144. Fonseca FN. Desenvolvimento tecnológico de fitoproduto a partir de Justicia pectoralis - Chambá: obtenção do extrato seco padronizado (CLAE-DAD) e avaliação farmacológica: Universidade Federal do Ceará; 2009.

145. Reich E, Schibli A. High-Performance Thin-Layer Chromatography for the Analysis of Medicinal Plants2011.

146. Espin JC, Morales M, Varon R, Tudela J, Garcia-Canovas F. A continuous spectrophotometric method for determining the monophenolase and diphenolase activities of apple polyphenol oxidase. Anal Biochem. 1995;231(1):237-46.

147. Cabanes J, Chazarra S, Garcia-Carmona F. Kojic acid, a cosmetic skin whitening agent, is a slow-binding inhibitor of catecholase activity of tyrosinase. $J$ Pharm Pharmacol. 1994;46(12):982-5.

148. Li HR, Habasi M, Xie LZ, Aisa HA. Effect of chlorogenic acid on melanogenesis of B16 melanoma cells. Molecules. 2014;19(9):12940-8.

149. Kang TY, Yang HR, Zhang J, Li D, Lin J, Wang L, et al. The studies of chlorogenic acid antitumor mechanism by gene chip detection: the immune pathway gene expression. J Anal Methods Chem. 2013;2013:617243. 
150. Yun N, Kang JW, Lee SM. Protective effects of chlorogenic acid against ischemia/reperfusion injury in rat liver: molecular evidence of its antioxidant and antiinflammatory properties. J Nutr Biochem. 2012;23(10):1249-55.

151. Xu Y, Chen J, Yu X, Tao W, Jiang F, Yin Z, et al. Protective effects of chlorogenic acid on acute hepatotoxicity induced by lipopolysaccharide in mice. Inflamm Res. 2010;59(10):871-7.

152. Ji L, Jiang $P$, Lu B, Sheng Y, Wang X, Wang Z. Chlorogenic acid, a dietary polyphenol, protects acetaminophen-induced liver injury and its mechanism. J Nutr Biochem. 2013;24(11):1911-9.

153. Shi H, Dong L, Dang X, Liu Y, Jiang J, Wang Y, et al. Effect of chlorogenic acid on LPS-induced proinflammatory signaling in hepatic stellate cells. Inflamm Res. 2013;62(6):581-7.

154. Shi H, Dong L, Bai Y, Zhao J, Zhang Y, Zhang L. Chlorogenic acid against carbon tetrachloride-induced liver fibrosis in rats. Eur J Pharmacol. 2009;623(13):119-24.

155. Hunyadi A, Martins A, Hsieh TJ, Seres A, Zupkó I. Chlorogenic acid and rutin play a major role in the in vivo anti-diabetic activity of Morus alba leaf extract on type II diabetic rats. PLoS One. 2012;7(11):e50619.

156. Kamalakkannan N, Prince PSM. Antihyperglycaemic and Antioxidant Effect of Rutin, a Polyphenolic Flavonoid, in Streptozotocin-Induced Diabetic Wistar Rats. Basic Clin Pharmacol Toxicol. 2006;98:97-103.

157. Fuentes O, Fuentes M, Badilla S, Troncoso F. Maqui (Aristotelia chilensis) and rutin (quercetin-3-O-rutinoside) protects against the functional impairment of the endothelium-dependent vasorelaxation caused by a reduction of nitric oxide availability in diabetes. Boletín Latinoamericano y del Caribe de Plantas Medicinales y Aromáticas. 2013;12(3):220 - 9.

158. Ola MS, Ahmed MM, Ahmad R, Abuohashish HM, Al-Rejaie SS, Alhomida AS. Neuroprotective Effects of Rutin in Streptozotocin-Induced Diabetic Rat Retina. J Mol Neurosci. 2015;56(2):440-8.

159. Tongjaroenbuangam W, Ruksee N, Chantiratikul P, Pakdeenarong N, Kongbuntad W, Govitrapong P. Neuroprotective effects of quercetin, rutin and okra (Abelmoschus esculentus Linn.) in dexamethasone-treated mice. Neurochem Int. $2011 ; 59(5): 677-85$. 
160. Nakayama M, Aihara M, Chen YN, Araie M, Tomita-Yokotani K, Iwashina T. Neuroprotective effects of flavonoids on hypoxia-, glutamate-, and oxidative stressinduced retinal ganglion cell death. Mol Vis. 2011;17:1784-93.

161. Arjumand W, Seth A, Sultana S. Rutin attenuates cisplatin induced renal inflammation and apoptosis by reducing NFKB, TNF- $\alpha$ and caspase- 3 expression in wistar rats. Food Chem Toxicol. 2011;49(9):2013-21.

162. Rodrigues HG, Diniz YSA, Faine LA, Almeida JA, Fernandes AAH, Novelli ELB. Suplementação nutricional com antioxidantes naturais: efeito da rutina na concentração de colesterol-HDL Rev Nutr. 2003;16(3):315-20.

163. Han Y, Haraguchi T, Iwanaga S, Tomotake H, Okazaki Y, Mineo S, et al. Consumption of some polyphenols reduces fecal deoxycholic acid and lithocholic acid, the secondary bile acids of risk factors of colon cancer. J Agric Food Chem. 2009;57(18):8587-90.

164. Valentová K, Vrba J, Bancírová M, Ulrichová J, Křen V. Isoquercitrin: pharmacology, toxicology, and metabolism. Food Chem Toxicol. 2014;68:267-82.

165. Jung SH, Kim BJ, Lee EH, Osborne NN. Isoquercitrin is the most effective antioxidant in the plant Thuja orientalis and able to counteract oxidative-induced damage to a transformed cell line (RGC-5 cells). Neurochem Int. 2010;57(7):713-21. 166. Amado NG, Cerqueira DM, Menezes FS, da Silva JF, Neto VM, Abreu JG. Isoquercitrin isolated from Hyptis fasciculata reduces glioblastoma cell proliferation and changes beta-catenin cellular localization. Anticancer Drugs. 2009;20(7):543-52. 167. Magalingam KB, Radhakrishnan A, Haleagrahara N. Protective effects of quercetin glycosides, rutin, and isoquercetrin against 6-hydroxydopamine (6-OHDA)induced neurotoxicity in rat pheochromocytoma (PC-12) cells. Int J Immunopathol Pharmacol. 2015.

168. Rogerio AP, Kanashiro A, Fontanari C, da Silva EV, Lucisano-Valim YM, Soares EG, et al. Anti-inflammatory activity of quercetin and isoquercitrin in experimental murine allergic asthma. Inflamm Res. 2007;56(10):402-8.

169. Si YX, Yin SJ, On S, Wang ZJ, Ye S, Yan L, et al. An integrated study of tyrosinase inhibition by rutin: progress using a computational simulation. J Biomol Struct Dyn. 2012;29(5):999-1012.

170. Ziaullah, Bhullar KS, Warnakulasuriya SN, Rupasinghe HP. Biocatalytic synthesis, structural elucidation, antioxidant capacity and tyrosinase inhibition activity 
of long chain fatty acid acylated derivatives of phloridzin and isoquercitrin. Bioorg Med Chem. 2013;21(3):684-92.

171. Ohguchi K, Nakajima C, Oyama M, linuma M, Itoh T, Akao Y, et al. Inhibitory effects of flavonoid glycosides isolated from the peel of Japanese persimmon (Diospyros kaki 'Fuyu') on melanin biosynthesis. Biol Pharm Bull. 2010;33(1):122-4.

172. Silva RAH. Estudo da ação do extrato bruto de Morus nigra L. (Moreaceae) e frações fenólicas sobre a atividade antimicrobiana e geração de espécies reativas do oxigênio e nitrogênio: in vitro com ensaios "químicos", enzimáticos, e celular. Araraquara: Universidade Estadual Paulista; 2012.

173. Jia D-D, Li S-F, Yang H-L. RP-HPLC Determination of Rutin and Isoquercitrin in Mulberry Leaves(Morus alba L.). Food Science. 2008;29(8):499-501.

174. Memon AA, Memon N, Luthria DL, Bhanger MI, Pitafi AA. Phenolic acids profiling and antioxidant potential of mulberry (Morus laevigataW., Morus nigra L., Morus alba L.) leaves and fruits grown in Pakistan. Polish Journal of Food and Nutrition Sciences. 2010;60(1):25-32.

175. Pawlowska AM, Oleszek W, Braca A. Quali-quantitative analyses of Flavonoids of Morus nigra L. and Morus alba L. (Moraceae) fruits. J Agric Food Chem. 2008;56(9):3377-80.

176. Gundogdu M, Muradoglu F, Gazioglu Sensoy RI, Yilmaz H. Determination of fruit chemical properties of Morus nigra L., Morus alba L. and Morus rubra L. by HPLC. Sci Hortic. 2011;132:37-41.

177. Katsube T, Imawaka N, Kawano Y, Yamazaki Y, Shiwaku K, Yamane Y. Antioxidant flavonol glycosides in mulberry (Morus alba L.) leaves isolated based on LDL antioxidant activity. Food Chem. 2006;97:25-31.

178. Ribani M, Bottoli CBG, Collins CH, Jardim ICSF, Melo LFC. Validação em Métodos Cromatográficos e Eletroforéticos. Quim Nova. 2004;27(5):771-80.

179. Shabir GA. Validation of high-performance liquid chromatography methods for pharmaceutical analysis. Understanding the differences and similarities between validation requirements of the US Food and Drug Administration, the US Pharmacopeia and the International Conference on Harmonization. J Chromatogr A. 2003;987(1-2):57-66.

180. Kim Y-H, Cho ML, Kim D-B, Shin G-H, Lee Ji-H, Lee JS, et al. The Antioxidant Activity and Their Major Antioxidant Compounds from Acanthopanax senticosus and A. koreanum. Molecules. 2015;20:13281-95. 
181. Bilbao MdLM, Andrés-Lacueva C, Jáuregui $O$, Lamuela-Raventós RM. Determination of flavonoids in a Citrus fruit extract by LC-DAD and LC-MS. Food Chem. 2007;101:1742-7.

182. Şarer E, Gokbulut A. Determination of caffeic and chlorogenic acids in the leaves and fruits of Vitex agnus-castus. Turkish Journal of Pharmaceutical Sciences. 2008;5(3):167-74.

183. Rivelli DP, Silva VV, Ropke CD, Miranda DV, Almeida RL, Sawada TCH, et al. Simultaneous determination of chlorogenic acid, caffeic acid and caffeine in hydroalcoholic and aqueous extracts of Ilex paraguariensis by HPLC and correlation with antioxidant capacity of the extracts by $\mathrm{DPPH}$. reduction. Brazilian Journal of Pharmaceutical Sciences. 2007;43(2).

184. Adham AN. Simultaneous estimation of caffeic and chlorogenic acid content in Ammi majus seed by TLCA and HPLC. International Journal of Pharmacy and Pharmaceutical Sciences. 2015;7(6):263-7.

185. Landim LP, Feitoza GS, Costa JGM. Development and validation of a HPLC method for the quantification of three flavonoids in a crude extract of Dimorphandra gardneriana. Rev Bras Farmacogn. 2013;23(1):58-64.

186. Dighe VV, Gokarn VN, Shambhu NS, Mestry DY, Adhyapak SS. Comparison of extraction techniques for quantitative determination of rutin from Morus alba Linn. by reverse phase high performance liquid chromatography. Int J Pharma Bio Sci. $2011 ; 2(1): 750-7$.

187. Landim LP, Feitoza GS, Costa JGM. Development and validation of a HPLC method for the quantification of three flavonoids in a crude extract of Dimorphandra gardneriana. Revista Brasileira de Farmacognosia. 2013;23(1).

188. Dutra DM, Barth CdS, Block LC, Quintão NLM, Couto AG, Cechinel Filho V, et al. Simultaneous determination of four phenolic compounds in extracts of aereal parts of Ipomoea pes-caprae (L.) R. Br. (Convolvulaceae) by HPLC-UV. Química Nova. 2014;37(9):1510-4.

189. Why Is My Peak Area Reducing With Flow Rate? Chromatography Today. 2014: 20-1

[Disponível em: https://http://www.chromatographytoday.com/articles/bioanalytical/40/chromatogr aphy today help desk/why is my peak area reducing with flow rate/1750/\%5D]. 190. Tallini LR. Validação de metodologias analíticas para quantificação de quercetina e canferol em extratos hidrolisados de folhas de Rubus erythrocladus, 
Rubus idaeus e Morus nigra e screening antifúngico destes extratos. Porto Alegre: Universidade Federal do Rio Grande do Sul; 2014.

191. Sigma-Aldrich. Product Information Cell Counting Kit-8. p. 7.

192. Dória GA, Santos AR, Bittencourt LS, Bortolin RC, Menezes PP, Vasconcelos $\mathrm{BS}$, et al. Redox-Active Profile Characterization of Remirea maritima Extracts and Its Cytotoxic Effect in Mouse Fibroblasts (L929) and Melanoma (B16F10) Cells. Molecules. 2015;20(7):11699-718.

193. Eo HJ, Park JH, Park GH, Lee MH, Lee JR, Koo JS, et al. Anti-inflammatory and anti-cancer activity of mulberry (Morus alba L.) root bark. BMC Complement Altern Med. 2014;14:200.

194. Drewa G, Schachtschabel DO, Pałgan K, Grzanka A, Sujkowska R. The influence of rutin on the weight, metastasis and melanin content of B16 melanotic melanoma in C57BL/6 mice. Neoplasma. 1998;45(4):266-71. 